\title{
\#USGS
}

Prepared in cooperation with the City of Tulsa, Oklahoma

\section{Comparison of Load Estimation Techniques and Trend Analysis for Nitrogen, Phosphorus, and Suspended Sediment in the Eucha-Spavinaw Basin, Northwestern Arkansas and Northeastern Oklahoma, 2002-10}

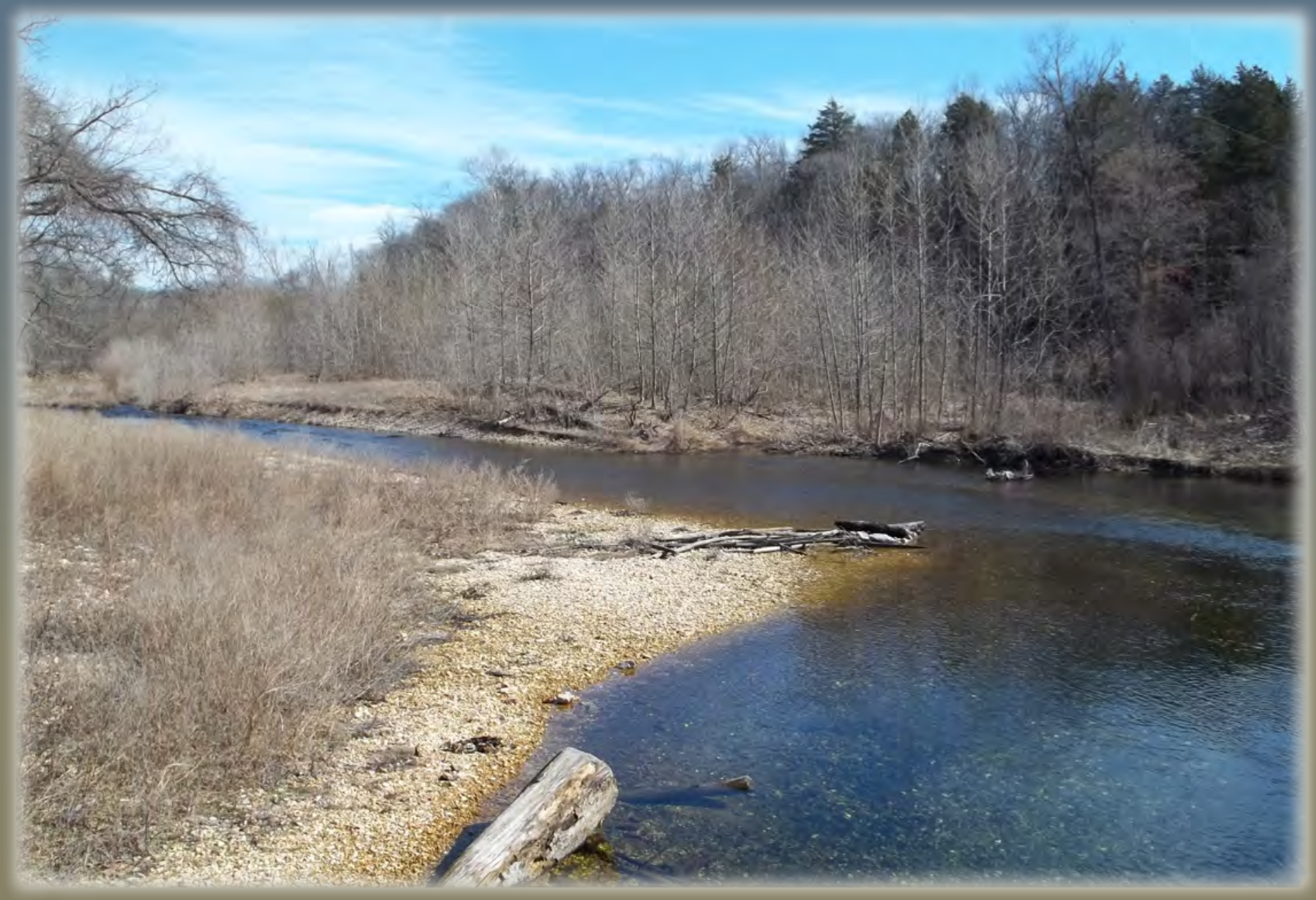

Scientific Investigations Report 2011-5172

Revised January 2013

U.S. Department of the Interior

U.S. Geological Survey 
Cover Photograph. Beaty Creek near Jay, Oklahoma, by Waylon Z. Marler. 


\section{Comparison of Load Estimation Techniques and Trend Analysis for Nitrogen, Phosphorus, and Suspended Sediment in the Eucha- Spavinaw Basin, Northwestern Arkansas and Northeastern Oklahoma, 2002-10}

By Rachel A. Esralew, William J. Andrews, Monica L. Allen, and Carol J. Becker

Prepared in cooperation with the City of Tulsa, Oklahoma

Scientific Investigations Report 2011-5172

Revised January 2013 


\title{
U.S. Department of the Interior \\ KEN SALAZAR, Secretary \\ U.S. Geological Survey \\ Marcia K. McNutt, Director
}

\section{U.S. Geological Survey, Reston, Virginia: 2011}

\author{
This and other USGS information products are available at http://store.usgs.gov/ \\ U.S. Geological Survey \\ Box 25286, Denver Federal Center \\ Denver, CO 80225 \\ To learn about the USGS and its information products visit http://www.usgs.gov/ \\ 1-888-ASK-USGS
}

Any use of trade, product, or firm names is for descriptive purposes only and does not imply endorsement by the U.S. Government.

Although this report is in the public domain, permission must be secured from the individual copyright owners to reproduce any copyrighted materials contained within this report.Suggested citation:

Suggested citation:

Esralew, R.A., Andrews, W.J., Allen, M.L., and Becker, C.J., 2011, Comparison of load estimation techniques and trend analysis for nitrogen, phosphorus, and suspended sediment in the Eucha-Spavinaw basin, northwestern Arkansas and northeastern Oklahoma, 2002-10: U.S. Geological Survey Scientific Investigations Report 2011-5172, 58 p. (Revised January 2013) 


\section{Acknowledgments}

The authors would like to thank the staff of the USGS Tulsa Field Office for measuring streamflow and collecting samples for this report. The authors also appreciate the assistance with statistical matters provided by David Lorenz of the USGS Minnesota Water Science Center. We appreciate the help of Jerrod Smith of the USGS Oklahoma Water Science, Gloria Ferrell of the USGS North Carolina Water Science Center, and Ray West and Roy Foster of the City of Tulsa in reviewing draft versions of this report. 


\section{Contents}

Acknowledgments ...................................................................................................................

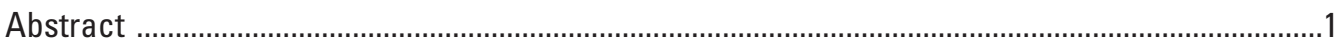

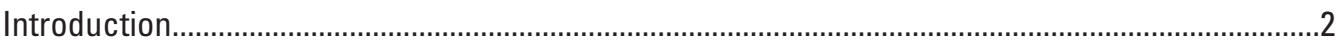

Changes in Nitrogen, Phosphorus, and Suspended-Sediment Transport in the

Eucha-Spavinaw Basin ..............................................................................................

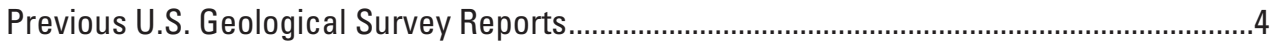

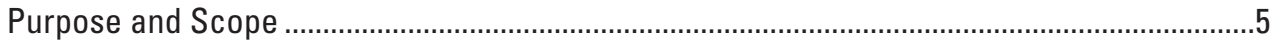

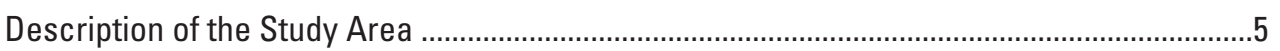

Streamflow in the Eucha-Spavinaw Basin .....................................................................

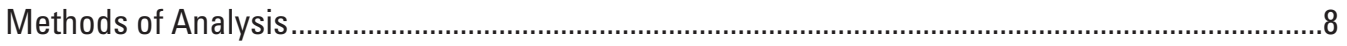

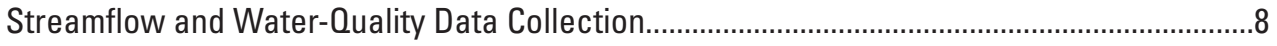

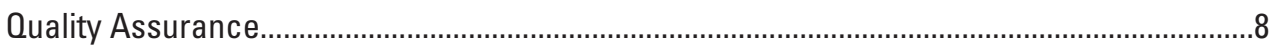

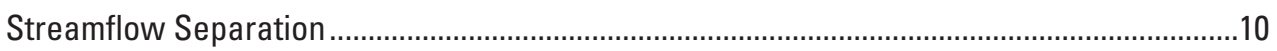

Development of Regression Equations to Estimate Concentrations and Loads .....................10

Comparison of Differences in Regression-Based Daily Load Estimates.........................11

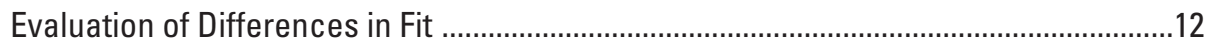

Methods of Analysis of Temporal Trends in Concentration...................................................12

Streamflows, Loads, and Instantaneous Concentrations in the Eucha-Spavinaw

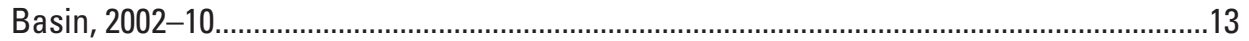

Water-Quality Data Used to Develop Regression Equations .................................................13

Nitrogen and Phosphorus Concentrations ..................................................................13

Sediment Concentrations .............................................................................................14

Estimated Loads and Yields of Nitrogen, Phosphorus, and Suspended

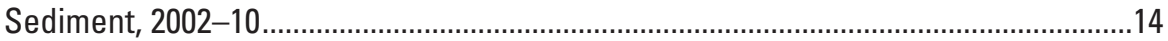

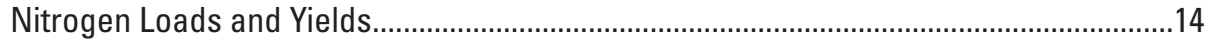

Phosphorus Loads and Yields .................................................................................16

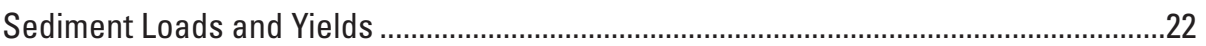

Estimated Mean Annual Nitrogen, Phosphorus, and Sediment Loads

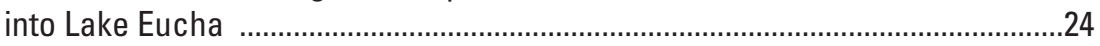

Estimation of Instantaneous Concentrations from Water-Quality Samples,

Streamflow, and Real-Time Continuous Water-Quality Data for 2005-10....................24

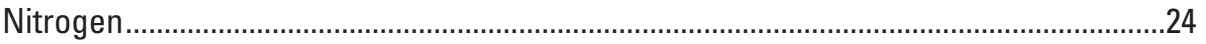

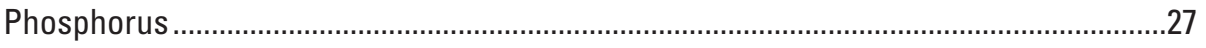

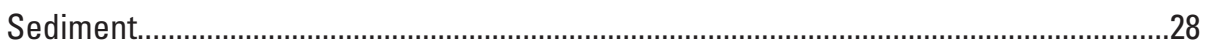

Comparison of Regression-Based
Load Estimates

Load Estimates...................................................................................................28

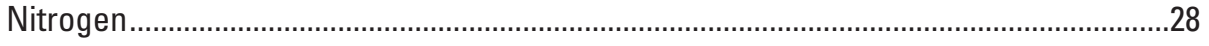

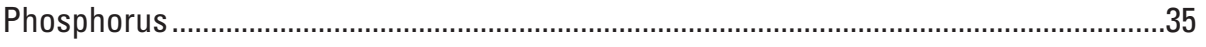

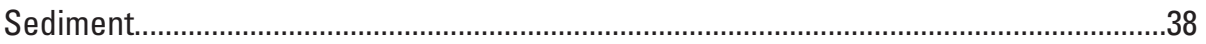

Evaluation of Temporal Trends in Nitrogen, Phosphorus, and Sediment

Concentrations in the Eucha-Spavinaw Basin, 2002-10 ……….......................................46

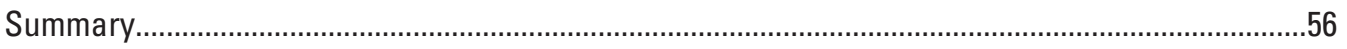

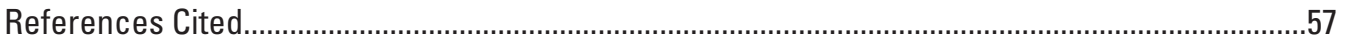




\section{Figures}

1. Map of the Eucha-Spavinaw basin, Arkansas and Oklahoma, with locations of selected streamflow-gaging and lake-level stations in the basin and towns with wastewater-treatment plants that discharge into streams in the basin

2. Map showing land use in the basins draining to Spavinaw Creek near Colcord, and Beaty Creek near Jay, Oklahoma, in the Eucha-Spavinaw basin, Arkansas and Oklahoma.....

3. Boxplots of distributions of total nitrogen concentrations in water samples collected from different time periods at streamflow-gaging stations in the Eucha-Spavinaw basin, Arkansas and Oklahoma

4. Boxplots of distributions of total phosphorus concentrations in water samples collected from different time periods at streamflow-gaging stations in the Eucha-Spavinaw basin, Arkansas and Oklahoma

5. Boxplots of distributions of suspended-sediment concentrations in water samples collected from different time periods at streamflow-gaging stations in the Eucha-Spavinaw basin, Arkansas and Oklahoma

6. Bar graphs of estimates of base-flow and runoff components of annual total nitrogen load and mean annual streamflow at water-quality monitoring stations in the Eucha-Spavinaw basin, Arkansas and Oklahoma, 2002-10

7. Bar graphs of estimates of base-flow and runoff components of annual total phosphorus load and mean annual streamflow, at water-quality monitoring stations in the Eucha-Spavinaw basin, Arkansas and Oklahoma, 2002-10

8. Bar graphs of estimates of base-flow and runoff components of suspended-sediment annual load and mean annual streamflow, at waterquality monitoring stations in the Eucha-Spavinaw basin, Arkansas and Oklahoma, 2002-10.

9. Graph of trends in error residuals of regression-estimated total phosphorus concentrations at Spavinaw Creek near Colcord, Oklahoma, streamflowgaging station, 2004-10.

10. Bar graphs of annual total nitrogen load estimated using two regression methods at Spavinaw Creek near Colcord, Oklahoma, and Beaty Creek near Jay, Okla., streamflow-gaging stations, 2005-10.

11. Bar graphs of comparison of relative percent differences between annual total nitrogen load estimated from two regression methods for Spavinaw Creek near Colcord, Oklahoma, and Beaty Creek near Jay, Okla., streamflow-gaging stations, 2006-10

12. Graphs of comparison of duration curves for estimated daily nitrogen loads at Spavinaw Creek near Colcord, Oklahoma, and Beaty Creek near Jay, Okla., using two regression methods

13. Graphs of comparison of measured and regression-estimated total nitrogen concentrations from $(A)$ INST $_{C}$ regressions that include physical waterquality constituents, streamflow, and seasonality as independent variables and $(B)$ alternate $\mathrm{INST}_{C}$ regressions that include streamflow and seasonality as independent variables.

14. Bar graphs of annual total phosphorus load estimated using two regression methods at Spavinaw Creek near Colcord, Oklahoma, and Beaty Creek near Jay, Okla., 2005-10. 
15. Bar graphs of comparison of relative percent differences between annual total phosphorus load estimated from two regression methods for Spavinaw Creek near Colcord, Oklahoma, and Beaty Creek near Jay, Oklahoma, 2006-10

16. Graphs of comparison of duration curves for estimated daily phosphorus loads at Spavinaw Creek near Colcord, Oklahoma, and Beaty Creek near Jay, Okla., using two regression methods

17. Graphs of comparison of measured and regression-estimated total phosphorus concentrations from $(A)$ INST $_{C}$ regressions based on physical water-quality constituents, streamflow, and seasonality as independent variables and $(B)$ alternate INST ${ }_{C}$ regressions based on streamflow and seasonality as independent variables

18. Graphs of comparison of difference in daily mean streamflow to difference in estimated phosphorus load between two regression methods at Spavinaw Creek near Colcord, Oklahoma, and Beaty Creek near Jay, Okla.

19. Bar graphs of suspended-sediment annual total load estimated using two regression methods, Spavinaw Creek near Colcord, and Beaty Creek near Jay, Oklahoma, 2005-10

20. Bar graphs of comparison of relative percent differences between suspended-sediment annual total load estimated from two regression methods for Spavinaw Creek near Colcord, Oklahoma, and Beaty Creek near Jay, Okla., 2006-10

21. Graphs of comparison of duration curves for estimated daily suspendedsediment loads at Spavinaw Creek near Colcord, Oklahoma, and Beaty Creek near Jay, Okla., streamflow-gaging stations using two regression methods

22. Graphs of comparison of measured and regression-estimated suspendedsediment concentrations from $(A)$ INST $_{C}$ regressions based on physical water-quality constituents, streamflow, and seasonality as independent variables and $(B)$ alternate INST $C$ regressions based on streamflow and seasonality as independent variables

23. Graphs of total phosphorus concentrations and LOESS trend lines at Spavinaw Creek near Maysville, Arkansas, showing $(A)$ total phosphorus concentrations with time, and $(B)$ flow-adjusted total phosphorus concentrations (error residuals) from a LOESS regression

24. Graphs of total phosphorus concentrations and LOESS trend lines at Spavinaw Creek near Cherokee City, Arkansas, showing $(A)$ total phosphorus concentrations with time, and $(B)$ flow-adjusted total phosphorus concentrations (error residuals) from a LOESS regression

25. Graphs of total phosphorus concentrations and LOESS trend lines at Spavinaw Creek near Sycamore, Oklahoma, showing $(A)$ total phosphorus concentrations with time, and $(B)$ flow-adjusted total phosphorus concentrations (error residuals) from a LOESS regression

26. Graphs of total phosphorus concentrations and LOESS trend lines at Spavinaw Creek near Colcord, Oklahoma, showing $(A)$ total phosphorus concentrations with time, and $(B)$ flow-adjusted total phosphorus concentrations (error residuals) from a LOESS regression 
27. Graphs of total phosphorus concentrations and LOESS trend lines at Beaty Creek near Jay, Oklahoma, showing $(A)$ total phosphorus concentrations with time, and $(B)$ flow-adjusted total phosphorus concentrations (error residuals) from a LOESS regression..

28. Graphs of suspended-sediment concentrations and LOESS trend lines at Spavinaw Creek near Maysville, Arkansas, showing $(A)$ suspendedsediment concentrations with time, and ( $B$ ) flow-adjusted suspendedsediment concentrations (error residuals) from a LOESS regression.

29. Graphs of suspended-sediment concentrations and LOESS trend lines at Spavinaw Creek near Sycamore, Oklahoma, showing $(A)$ suspendedsediment concentrations with time, and $(B)$ flow-adjusted suspendedsediment concentrations (error residuals) from a LOESS regression.

30. Graphs of suspended-sediment concentrations and LOESS trend lines at Beaty Creek near Jay, Oklahoma, showing $(A)$ suspended-sediment concentrations with time, and $(B)$ flow-adjusted suspended-sediment concentrations (error residuals) from a LOESS regression.

\section{Tables}

1. Estimates of fertilizer application, population of cattle and calves, and number of broilers and other chickens sold for counties in the EuchaSpavinaw basin, Arkansas and Oklahoma, 2002 and 2007

2. Station information and streamflow statistics for streamflow-gaging stations in the Eucha-Spavinaw basin, Arkansas and Oklahoma

3. Regression equations for estimating daily mean loads (DMLs) of total nitrogen, total phosphorus, and sediment using streamflow, seasonality, and time at streamflow-gaging stations in the Eucha-Spavinaw basin, Arkansas and Oklahoma, 2002-10

4. Estimated mean annual total nitrogen, total phosphorus, and suspended sediment loads and yields using regression equations developed from concentrations in water-quality samples and streamflow, time, and seasonality, for water-quality monitoring stations in the Eucha-Spavinaw basin, Arkansas and Oklahoma, for the period 2002-10.

5. Summary of estimated mean annual total nitrogen, total phosphorus, and suspended-sediment loads to Lake Eucha, Oklahoma, 2002-10.

6. Regression equations for estimating instantaneous concentrations (INSTC) of total nitrogen, total phosphorus, and suspended sediment using physical water-quality constituents, streamflow, and seasonality, at Spavinaw Creek near Colcord, Oklahoma and Beaty Creek near Jay, Okla., streamflowgaging stations, 2004-10.

7. Alternate regression equations used for estimating instantaneous concentrations of total nitrogen, total phosphorus, and suspended sediment using streamflow and seasonality parameters for Spavinaw Creek near Colcord, Oklahoma, and Beaty Creek near Jay, Okla., streamflow-gaging stations, 2004-10. 
8. Estimated mean annual total nitrogen, total phosphorus, and suspended-sediment loads and yields by using two different regression equations for streamflow-gaging stations in the Eucha-Spavinaw basin, Arkansas and Oklahoma, 2002-10.

9. Wilcoxon signed-rank test results comparing daily loads estimated from two different regression methods at two streamflow-gaging stations in the Eucha-Spavinaw basin, 2004-10.

10. Results of Kendall's tau and Seasonal Kendall tests of time trends of concentrations of nitrate plus nitrite, total nitrogen, total phosphorus, and suspended sediment in water samples collected at streamflow-gaging stations in the Eucha-Spavinaw basin, Arkansas and Oklahoma, 2002-10

\section{Conversion Factors}

Inch/Pound to SI

\begin{tabular}{|c|c|c|}
\hline Multiply & By & To obtain \\
\hline \multicolumn{3}{|c|}{ Length } \\
\hline inch (in.) & 2.54 & centimeter $(\mathrm{cm})$ \\
\hline inch (in.) & 25.4 & millimeter $(\mathrm{mm})$ \\
\hline mile (mi) & 1.609 & kilometer $(\mathrm{km})$ \\
\hline \multicolumn{3}{|c|}{ Area } \\
\hline acre & 0.4047 & hectare (ha) \\
\hline acre & 4,047 & square meter $\left(\mathrm{m}^{2}\right)$ \\
\hline acre & 0.004047 & square kilometer $\left(\mathrm{km}^{2}\right)$ \\
\hline square foot $\left(\mathrm{ft}^{2}\right)$ & 929.0 & square centimeter $\left(\mathrm{cm}^{2}\right)$ \\
\hline square mile $\left(\mathrm{mi}^{2}\right)$ & 259.0 & hectare (ha) \\
\hline square mile $\left(\mathrm{mi}^{2}\right)$ & 2.590 & square kilometer $\left(\mathrm{km}^{2}\right)$ \\
\hline \multicolumn{3}{|c|}{ Volume } \\
\hline cubic foot $\left(\mathrm{ft}^{3}\right)$ & 28.32 & cubic decimeter $\left(\mathrm{dm}^{3}\right)$ \\
\hline cubic foot $\left(\mathrm{ft}^{3}\right)$ & 0.02832 & cubic meter $\left(\mathrm{m}^{3}\right)$ \\
\hline \multicolumn{3}{|c|}{ Flow rate } \\
\hline cubic foot per second $\left(\mathrm{ft}^{3} / \mathrm{s}\right)$ & 0.02832 & cubic meter per second $\left(\mathrm{m}^{3} / \mathrm{s}\right)$ \\
\hline million gallons per day (Mgal/d) & 0.04381 & cubic meter per second $(\mathrm{m} 3 / \mathrm{s})$ \\
\hline \multicolumn{3}{|c|}{ Mass } \\
\hline pound, avoirdupois (lb) & 0.4536 & kilogram (kg) \\
\hline ton, short $(2,000 \mathrm{lb})$ & 0.9072 & megagram (mg) \\
\hline pound per year & 0.4536 & kilogram per year (kg/yr) \\
\hline pound per year per square mile $\left(\mathrm{lb} / \mathrm{yr} / \mathrm{mi}^{2}\right)$ & & $\begin{array}{l}\text { kilogram per year per square mile } \\
\left(\mathrm{kg} / \mathrm{yr} / \mathrm{mi}^{2}\right)\end{array}$ \\
\hline
\end{tabular}

Horizontal coordinate information is referenced to the North American Datum of 1983 (NAD 83).

Concentrations of chemical constituents in water are given either in milligrams per liter (mg/L) or micrograms per liter $(\mu \mathrm{g} / \mathrm{L})$. 


\title{
Comparison of Estimation Techniques and Trend Analysis of Nitrogen, Phosphorus, and Sediment in the Eucha-Spavinaw Basin, Northwestern Arkansas and Northeastern Oklahoma, 2002-10
}

\author{
By Rachel A. Esralew, William J. Andrews, Monica L. Allen, and Carol J. Becker
}

\section{Abstract}

The City of Tulsa, Oklahoma, uses water from Lake Eucha and Spavinaw Lake in the Eucha-Spavinaw basin of northwestern Arkansas and northeastern Oklahoma for public water supply. Increases in algal biomass, which cause taste and odor problems in drinking water produced from the lakes, may be attributable to increases in nitrogen and phosphorus concentrations in the lakes and in streams discharging to the lakes. To evaluate transport of nitrogen, phosphorus, and suspended sediment in this basin, loads and temporal trends were evaluated for five streamflow-gaging stations in the Spavinaw and Beaty Creek basins.

Two approaches were used to develop regression equations for estimation of loads and yields of nitrogen, phosphorus, and sediment. The first approach used regression equations referred to as daily mean load $\left(\mathrm{DM}_{\mathrm{L}}\right)$ regressions, developed from water-quality samples and daily mean streamflow data collected from 2002 through 2010 at five streamflow-gaging stations in the basin. This approach was updated to compare loading results with those used in previous investigations. The second approach used regression equations, referred to as instantaneous continuous (INST ${ }_{C}$ ) regressions, developed from continuous measurements of physical water-quality constituents (specific conductance, temperature, and turbidity, and streamflow data) obtained from 2004 through 2010 to estimate loads of nitrogen, phosphorus, and sediment at two of the streamflow-gaging stations, Spavinaw Creek near Colcord, Okla., and Beaty Creek near Jay, Okla. Daily, annual, and mean annual loads estimated from these two regression methods were compared for the period 2005-10.

Based on estimates obtained using $\mathrm{DM}_{\mathrm{L}}$ regressions, mean annual loads of $1,640,000$ pounds of nitrogen, 99,900 pounds of phosphorus, and 116,000,000 pounds of sediment were transported into Lake Eucha from the Spavinaw and Beaty Creek basins. Estimated annual loads of nitrogen and phosphorus delivered to Lake Eucha from the Spavinaw and Beaty Creek basins during 2002-10 were
2.5 to 7.8 percent less, respectively, than the loads of those constituents discharged to Lake Eucha from 2002-09, indicating that nitrogen and phosphorus loads in 2010 were less than loads typical for the period 2002-09.

Daily, annual, and mean annual load estimates varied substantially, depending on streamflow conditions and the independent variables used to develop regressions. Daily and annual loads estimated from INST $_{C}$ regressions that included turbidity, streamflow, temperature, specific conductance, and seasonality fit better with the field data than loads estimated from $\mathrm{DM}_{\mathrm{L}}$ regressions that included streamflow, seasonality, and time. Loads estimated from the INST $_{C}$ regression generally were greater than those estimated from the $\mathrm{DM}_{\mathrm{L}}$ regression. Relative percent differences in the mean annual total nitrogen load estimated by the $\mathrm{INST}_{C}$ and $\mathrm{DM}_{L}$ regressions were within 2 percent for Spavinaw Creek near Colcord, and Beaty Creek near Jay, Okla. The relative percent difference between the two types of regressions for estimates of mean annual total phosphorus loads at the two streamflowgaging stations was 27.7 for Spavinaw Creek near Colcord, Okla., and only -2.6 percent for Beaty Creek near Jay, Okla. The relative percent difference between mean annual suspended-sediment loads at the streamflow-gaging stations was -38.6 percent for Spavinaw Creek near Colcord, Okla., and -122.7 percent for Beaty Creek near Jay, Okla. The DM regression may have substantially underestimated phosphorus load at the Spavinaw Creek near Colcord, Okla., streamflowgaging station in wet years and overestimated sediment load at both streamflow-gaging stations in wet years.

Temporal trends in flow-adjusted nitrate-nitrogen, nitrogen, phosphorus, and suspended-sediment concentrations were analyzed for the five streamflow-gaging stations for the period 2001-10. No significant trends were observed for nitrate plus nitrite-nitrogen or total nitrogen concentrations at any streamflow-gaging station. There were significant upward trends in phosphorus concentrations in water samples collected during base-flow conditions at the Spavinaw Creek near Maysville, Okla., streamflow-gaging station and during runoff conditions for the Beaty Creek near Jay, 
Okla., streamflow-gaging station (3.5 to 4.2 percent per year). There were significant downward trends in phosphorus concentrations in base-flow and runoff samples collected at the Spavinaw Creek near Cherokee City, Sycamore, and Colcord, Okla., streamflow-gaging stations ( -4.9 to -12.9 percent per year). There were significant downward trends in suspendedsediment concentration at the Spavinaw Creek near Maysville, and Sycamore, Okla., and the Beaty Creek near Jay, Okla., streamflow-gaging stations (-1.5 to -1.8 percent per year). No significant trends were detected in suspended-sediment concentration for the Spavinaw Creek near Cherokee City, and Colcord, Okla., streamflow-gaging stations.

Possible causes for downward trends in phosphorus concentrations include decreases in phosphorus discharges from a wastewater-treatment plant upstream from the Spavinaw Creek near Cherokee City, Okla., streamflow-gaging station, and implementation of best management practices in the basin. Downward trends in sediment concentrations may be related to effects of best management practices in the basin.

\section{Introduction}

The City of Tulsa, Oklahoma, uses Lake Eucha and Spavinaw Lake in the Eucha-Spavinaw basin in northwestern Arkansas and northeastern Oklahoma for public water supply (fig. 1). Construction of Spavinaw Dam (U.S. Geological Survey (USGS) lake-level station at Spavinaw Lake, station identifier 07191300, fig. 1) on Spavinaw Creek began in 1922 and was completed in 1924 (Oklahoma Water Resources Board, 2002). A series of 60-mile-long pipelines was constructed to transfer water from the base of the Spavinaw Dam to a drinking-water-treatment plant in Tulsa. In 1950, city officials decided to create an impoundment of Spavinaw Creek 4 miles upstream from Spavinaw Lake to serve as "an environmental and hydrologic barrier" for Spavinaw Lake to ensure a constant supply of clean water. This second dam came to be known as Eucha Dam (USGS lake-level station at Lake Eucha, station identifier 07191285, fig. 1) that was finished in 1954 to impound Lake Eucha (fig. 1) (City of Tulsa City Services, 2008a).

The Eucha-Spavinaw water-supply system continues to be used for public water supply as well as for recreation, fish and wildlife, agriculture, and aesthetics (City of Tulsa City Services, 2008b). On average, the Eucha-Spavinaw watersupply system provides 59 million gallons per day (Mgal/d) to the Tulsa metropolitan area. During peak demand, the system can produce a maximum of $100 \mathrm{Mgal} / \mathrm{d}$ (City of Tulsa City Services, 2008b).

Taste and odor problems in drinking water have been reported by water customers to the City of Tulsa (COT) (City of Tulsa City Services, 2008c). The Tulsa Metropolitan Utility Authority (TMUA) spent millions of dollars from 1998-2005 to eliminate taste and odor problems, likely attributable to the chemicals produced by blue-green algae, particularly geosmin, in drinking water from the Eucha-Spavinaw watersupply system (City of Tulsa City Services, 2008c; Oklahoma Water Resources Board, 2002). Increases in algal biomass in the lakes are believed to be the result of increases in nitrogen and phosphorus concentrations in tributaries of the lakes (City of Tulsa City Services, 2008c). Elevated nitrogen and phosphorus concentrations promote algae growth in streams (Sharpley, 1995; U.S. Geological Survey, 1999) and accelerate eutrophication (plant growth and dissolved oxygen depletion) in lakes (Daniel and others, 1998; U.S. Geological Survey, 1999). Reduction in suspended sediments also may increase algal growth by reducing water turbidity and increasing penetration of sunlight into water (Gloria Ferrell, U.S. Geological Survey, written commun., 2011). Studies of nitrogen and phosphorus loading in this basin began with a 1997 Oklahoma Conservation Commission report indicating increasing nitrogen and phosphorus concentrations in Spavinaw Creek, a main tributary to Lake Eucha (fig. 1), between 1975 and 1995 (Wagner and Woodruff, 1997). Lake Eucha and Spavinaw Lake were enriched in nitrogen and phosphorus (phosphorus was the limiting nutrient) and had high to excessive levels of algae in 2000 (Oklahoma Water Resources Board, 2002).

Nitrogen and phosphorus can enter streams in discharges from wastewater-treatment plants (point sources) and in agricultural and urban runoff (nonpoint sources) (Oklahoma Water Resources Board, 2002). The main sources of elevated nitrogen and phosphorus concentrations in streams in the Eucha-Spavinaw basin are nonpoint sources (such as runoff from fertilized pastures) and point sources (primarily municipal wastewater discharge) (Tortorelli, 2006; Tortorelli, 2008; City of Tulsa, 2010). Storm and others (2002) reported that runoff from pastures to which animal manure or commercial fertilizer had been applied was a major source of nitrogen and phosphorus delivered to streams in this basin.

One possible major contributor of nitrogen and phosphorus to the creeks discharging to Lake Eucha and Spavinaw Lake is the phosphorous-rich waste produced by commercial poultry operations in the basin. This waste is routinely spread onto fields as fertilizer and can be a source of nitrogen and phosphorous washed into streams as nonpointsource pollution, which ultimately reaches the water-supply lakes and promotes growth of unwanted algae (Storm and others, 2002). Another source of nitrogen and phosphorus is a municipal wastewater-treatment plant, operated by the City of Decatur, Arkansas (referred to in the remainder of this report as the "Decatur wastewater-treatment plant"), which releases municipal wastewater effluent, after secondary treatment, into Columbia Hollow, a tributary of Spavinaw Creek (U.S. Environmental Protection Agency and Oklahoma Department of Environmental Quality, 2009). Concentrations of nitrogen and phosphorus in streams receiving municipal wastewater can exceed those in streams draining agricultural areas (Petersen and others, 1998). 


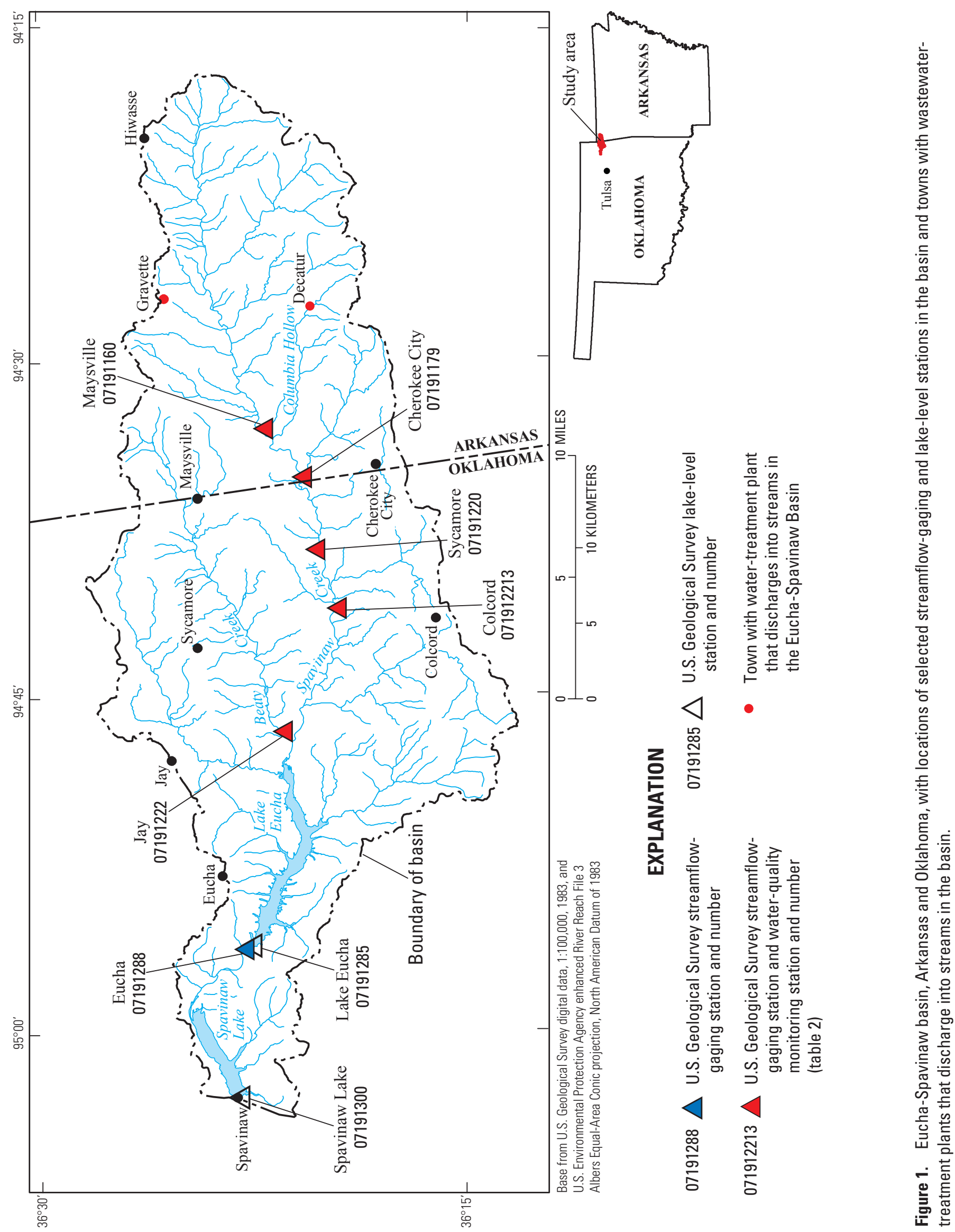


Nitrogen and phosphorus concentrations in streams vary throughout the year, in response to precipitation, streamflow, quantities and composition of wastewater effluent, and the timing of fertilizer and manure applications (U.S. Geological Survey, 1999). Nitrogen and phosphorus concentrations in streams generally are greater during runoff periods than during base-flow periods, especially in the spring and summer after fertilizer application. Sedimentbound and particulate forms of nitrogen (mostly organic) and phosphorus are likely to be delivered to the stream during high streamflow as a result of hillslope and channel bank erosion as well as resuspension of streambed sediments. Increases in concentrations of phosphorus and organic nitrogen are typically associated with increases in suspendedsediment concentrations. Increased nitrogen and phosphorus concentrations also were measured in streams during low flows, possibly because of minimal dilution of point sources, such as effluent from wastewater-treatment plants

(U.S. Geological Survey, 1999).

Water-quality data collected at five USGS-operated streamflow-gaging stations (referred to in the remainder of this report as "stations") in the basin were evaluated: (1) Spavinaw Creek near Maysville, Arkansas; (2) Spavinaw Creek near Cherokee City, Arkansas; (3) Spavinaw Creek near Sycamore, Okla.; (4) Spavinaw Creek near Colcord, Okla.; and (5) Beaty Creek near Jay, Okla. (fig. 1). For the remainder of this report, these stations are referred to as the Maysville station, Cherokee City station, Sycamore station, and Colcord station on Spavinaw Creek (or collectively as the "Spavinaw Creek stations"), and the Beaty Creek station, respectively.

Prior to July 2001, water-quality samples were collected in the Eucha-Spavinaw basin on a monthly schedule. Most of those water samples were collected during base-flow (non-runoff) conditions because runoff events are variable and infrequent. The lack of samples collected during runoff caused underestimation of true nitrogen and phosphorus concentrations, loads, and yields in the basin. From July 2001 through 2010, the USGS, in cooperation with COT, has supplemented monthly collection of nitrogen and phosphorus samples with collection of nitrogen, phosphorus, and suspended-sediment samples during six runoff events per year to expand the range of streamflow over which water-quality data were collected.

\section{Changes in Nitrogen, Phosphorus, and Suspended-Sediment Transport in the Eucha-Spavinaw Basin}

To decrease eutrophication in the Eucha-Spavinaw basin, quantities of nitrogen and phosphorus in runoff to surface water or seepage into groundwater need to be reduced. Since 1998, efforts to minimize eutrophication in the basin have included reducing land applications of poultry litter, implementing best management practices (BMPs) to reduce runoff of nitrogen, phosphorus, and sediment; and reduction of nitrogen and phosphorus concentrations in municipal wastewater effluent.

Land applications of poultry litter as fertilizer probably have decreased since 2004. In 2001, an estimated 1,500 tons of nitrogen and phosphorous-rich animal wastes were generated in this basin annually (Tulsa Metropolitan Utility Authority, 2001). A lawsuit filed by the COT against several poultry-producing companies in 2001 was settled out of court in 2003 and starting in 2004, substantial reductions in land application of poultry litter in the basin commenced (City of Tulsa, 2010).

BMPs designed to improve water quality have been implemented in the Eucha-Spavinaw basin since 1998, including creation of conservation easements, protection of riparian buffers, streambank stabilization, exclusion of cattle from waterways, and reductions in poultry litter application (Oklahoma Conservation Commission, 2007; U.S. Environmental Protection Agency, 2007). BMPs were implemented in the Beaty Creek basin for the period 1998-2003 and in the Spavinaw Creek basin from 2003-2008; landowners have continued to keep BMP measures in place (Oklahoma Conservation Commission, 2007; Oklahoma Conservation Commission, 2009). A paired-basin study in the Beaty Creek basin indicated that the upward trend of phosphorus loading to Beaty Creek decreased by 31 percent after BMPs were implemented (U.S. Environmental Protection Agency, 2007).

Point-source discharges of municipal wastewater also have been reduced in the basin. As a result of a 2003 settlement, effluent discharge from the Decatur wastewatertreatment plant was required to meet a monthly average of 1 milligram per liter (mg/L) of phosphorus, an 80-percent reduction compared to previous discharges (Oklahoma Department of Environmental Quality, 2007). Improvements to the wastewater-treatment plant were operational as of January 2006 (Oklahoma Department of Environmental Quality, 2007). Haggard and Stoner (2009) analyzed average monthly effluent total phosphorus concentrations before and after the 2006 plant upgrade and found significantly less and less variable concentrations of total phosphorus in wastewater discharge since the upgrade.

\section{Previous U.S. Geological Survey Reports}

Several reports characterizing nitrogen and phosphorus in the Eucha-Spavinaw basin have been published, including Wagner and Woodruff (1997), Haggard (2000), Haggard and others (2001), Storm and others (2001, 2002), Tulsa Metropolitan Utility Authority (2001), Delaune and others (2006), Tortorelli (2006, 2008), Christensen and others (2008), Haggard and Stoner (2009), City of Tulsa (2010), and Esralew and Tortorelli (2010). Because this report is an update to several previously published USGS reports, only those reports are described in the remainder of this section.

The USGS, in cooperation with COT, investigated and summarized characteristics of total nitrogen and total 
phosphorus concentrations and provided estimates of nitrogen and phosphorus loads, yields, and flow-weighted concentrations in the Eucha-Spavinaw basin from January 2002 through December 2009 (Esralew and Tortorelli, 2010). That report is an update of previous reports in which total nitrogen and phosphorus concentrations, loads, and yields were summarized for the periods $2002-04$ and 2002-06 (Tortorelli, 2006, 2008).

Tortorelli $(2006,2008)$ and Esralew and Tortorelli (2010) used the S-LOADEST program (Dave Lorenz, U.S. Geological Survey, written commun., 2006) to estimate loads and yields. The S-LOADEST program provides estimates of constituent load by the rating-curve method, which is a regression-based approach that incorporates bias-correction procedures (Cohn and others, 1989; Crawford, 1991). Regression equations were developed for each station using streamflow, time, and seasonality as principal independent variables. These regression equations were used to estimate daily mean loads for days when samples were not collected. Those estimated daily mean loads were summed to compute total loads for seasons and years. Nitrogen and phosphorus loads and yields were used to characterize annual and seasonal inputs from Beaty and Spavinaw Creeks to Lake Eucha. As new water-quality and streamflow data become available, regression equations to estimate loads can be revised to provide more accurate estimates (D. Mueller, U.S. Geological Survey, written commun., 2010).

To better estimate nitrogen and phosphorus instantaneous concentrations for times when samples were not collected, continuous water-quality monitors were installed in 2004 and 2005 at the Colcord and Beaty Creek stations, respectively. Data from those monitors, which measure and record physical water-quality constituents (temperature, $\mathrm{pH}$, specific conductance, dissolved oxygen, and turbidity) at 15-60 minute intervals, were used to develop regression equations for estimation of nitrogen and phosphorus concentrations to physical water-quality constituents (Christensen and others, 2008). For the study described in this report, regression equations are formulated for the Beaty Creek and Colcord stations to estimate constituent concentrations in real time. Regression equations developed in Christensen and others (2008) were valid only for 2004-07, a period that was drier than normal.

Previous USGS reports (Tortorelli, 2006 and 2008; Christensen and others, 2008; Esralew and Tortorelli, 2010) did not analyze suspended-sediment (referred to in the rest of this report as "sediment") loads and yields. Characterization of sediment loads using regression methods is useful for understanding transport mechanisms of sediment and of sorbed nutrients such as phosphorus and organic nitrogen. Therefore, the USGS, in cooperation with the COT, used the periodic water-quality sample data collected at the five stations and continuous water-quality monitor data collected at two stations to provide the COT with an updated assessment of loading through 2010 that can be compared to loads estimated for 2002-09 in Esralew and Tortorelli (2010).
Significance of trends in nitrogen, phosphorus, and sediment concentrations was not analyzed in previous USGS reports because not enough data had been collected during runoff conditions. Changes in the land uses and nitrogen and phosphorus discharges in the basin may have caused significant trends in concentrations of nitrogen, phosphorus, and sediment since 2001. As of 2010, 9 years of runoff samples have been collected, sufficient for analyzing longterm trends in flow-adjusted (concentrations corrected for changes in streamflow) concentrations of nitrogen, phosphorus, and sediment. Such information can be used to evaluate the effectiveness of nitrogen- and phosphorusreduction measures in this basin.

\section{Purpose and Scope}

The purpose of this report is to compare and analyze load estimates computed using two types of regression methods for Beaty Creek and Colcord stations for 2005-10 and to analyze trends in flow-adjusted nitrogen, phosphorus, and sediment concentrations with time for five stations in the basin from 2002-10. In addition, this report summarizes concentrations of nitrogen and phosphorus nutrients at five stations in the Eucha-Spavinaw basin; updates nitrogen, phosphorus, and sediment loads and yields at selected sites in the basin using data from periodic runoff water-quality samples and continuous streamflow data from 2002-10; and updates regression equations used to estimate continuous nitrogen, phosphorus, and sediment concentrations using continuous measurements of physical water-quality constituents and streamflow and water-quality samples collected from 2004-10 for the Beaty Creek and Colcord stations.

\section{Description of the Study Area}

The Eucha-Spavinaw basin is a 389-square mile area in northwestern Arkansas (30 percent of the basin area) and northeastern Oklahoma (70 percent of the basin area) (fig. 1). Lake Eucha and Spavinaw Lake store water discharged from Spavinaw and Beaty Creeks to supply the Tulsa metropolitan area and other local water users (Oklahoma Water Resources Board, 2002). The basin is in the southwestern part of the Ozark Plateaus physiographic province (Fenneman, 1938) and is underlain by the cherty limestone of the Springfield Plateau aquifer (Adamski and others, 1995). Soils in the basin are mostly classified as silty loam or gravelly silty loam (Storm and others, 2002). The undulating karstic topography of the region is caused by extensive dissolution of carbonate bedrock. That dissolution facilitates infiltration of runoff to groundwater through subterranean conduits and rapid groundwater flow to streams (Tulsa Metropolitan Utility Authority, 2001). Losses of streamflow to groundwater, referred to as "losing conditions," also are common in the basin (J. Wellman, U.S. Geological Survey, written commun., 2007). 
Land in the Eucha-Spavinaw basin is dominated by pasture, hay fields, and forest, with interspersed minor amounts of urban land (fig. 2). The Spavinaw Creek basin has more forested land (39 percent) than the Beaty Creek basin (31 percent) and less land used for pasture and hay production (54 percent) than the Beaty Creek basin (62 percent) (fig. 2). Nitrogen and phosphorus concentrations typically are greater in Ozark streams draining agricultural lands than in streams draining forested lands (Petersen and others, 1998).

Livestock production is the primary form of agriculture in the basin; the basin is densely populated with poultry/beef cattle operations. Poultry litter is used widely as a fertilizer source for pastures in the study area (DeLaune and others, 2006, table 1). The significance of nitrogen and phosphorus related to agriculture in the basin is evident from the estimates of commercial fertilizer and manure applications for counties in the Eucha-Spavinaw basin (table 1). Commercial fertilizer and manure applied is likely to be greater in Benton County, Ark., than in Delaware County, Okla., based on livestock populations (fig. 2; U.S. Department of Agriculture, 2004 and 2009). Poultry litter application rates are greater in the Spavinaw Creek basin than in Beaty Creek basin (Storm and others, 2002, p. 25). As of 2007, poultry operations in the basin had the capacity to produce more than 160 million birds annually (U.S. Department of Agriculture, 2009; table 1). From 2002-2007, the amount of land fertilized with manure in the two counties that contain the basin decreased from 84,100 acres to 51,700 acres and land fertilized with commercial fertilizer decreased from 137,900 to 115,400 acres (U.S. Department of Agriculture, 2004 and 2009, table 1).

In 2009, human population in the basin was estimated to be 225,504 in Benton County, Ark., and 40,555 in Delaware County, Okla. (U.S. Census Bureau, 2009). Surface-water and groundwater use in 1995 were $41.1 \mathrm{Mgal} / \mathrm{d}$ and 8.8 $\mathrm{Mgal} / \mathrm{d}$, respectively, in Benton County and $2.6 \mathrm{Mgal} / \mathrm{d}$ and
1.9 Mgal/d, respectively, in Delaware County (Adamski and others, 1995). Most of this water is used for public supply and very little agricultural water use is reported for these two counties.

The Decatur wastewater-treatment plant discharged about $1.3 \mathrm{Mgal} / \mathrm{d}$ of wastewater to Spavinaw Creek in 1999 (Haggard and others, 2001; Storm and others, 2002; DeLaune and others, 2006). After improvements to the wastewater-treatment plant in 2006, the plant has a wasteload allocation permit of $2.2 \mathrm{Mgal} / \mathrm{d}$ and a discharge limit of $1 \mathrm{mg} / \mathrm{L}$ total phosphorus and $10 \mathrm{mg} / \mathrm{L}$ ammonia as nitrogen (U.S. Environmental Protection Agency, 2007; Oklahoma Department of Environmental Quality, 2009). A smaller wastewater-treatment plant located in the Spavinaw Creek basin (Gravette, Ark.) has a waste-load allocation permit of $0.56 \mathrm{Mgal} / \mathrm{d}$, but nitrogen and phosphorus contributions to Lake Eucha from that plant are considered to be substantially less than those of the Decatur plant because of the intermittent nature of the discharge from the smaller plant (U.S. Environmental Protection Agency and Oklahoma Department of Environmental Quality, 2009).

Mean annual precipitation in the basin from 1971-2000 was 48.9 inches (in.) (1971-2000), with September having the highest average monthly precipitation (5.55 in.) (Oklahoma Climatological Survey, 2009). Annual precipitation was used to determine differences in precipitation between years in the National Weather Service Climate Divisions, OK03-NE and AR01-NW, in the Eucha-Spavinaw basin (National Oceanic and Atmospheric Administration, 2011). From 2002-10, the wettest year was 2008 with 59.6 and 66.7 in. of precipitation in OK03-NE and AR01-NW, respectively; the driest year was 2005 with 32.3 and 33.6 in. of precipitation in OK03-NE and AR01-NW, respectively (National Oceanic and Atmospheric Administration, 2011).

Table 1. Estimates of fertilizer application, population of cattle and calves, and number of broilers and other chickens sold for counties in the Eucha-Spavinaw basin, Arkansas and Oklahoma, 2002 and 2007.

[modified from U.S. Department of Agriculture (2004, and 2009)]

\begin{tabular}{|c|c|c|c|c|c|c|c|c|c|c|}
\hline County & $\begin{array}{c}\text { Percentage } \\
\text { of county in } \\
\text { drainage } \\
\text { basin of } \\
\text { Beaty Creek } \\
\text { near Jay } \\
\text { (station } \\
\text { 07191222) } \\
\end{array}$ & $\begin{array}{c}\text { Percentage } \\
\text { of county in } \\
\text { drainage basin } \\
\text { of Spavinaw } \\
\text { Creek near } \\
\text { Colcord } \\
\text { (station } \\
\text { 071912213) } \\
\end{array}$ & $\begin{array}{c}\text { Farmland } \\
\text { (acres) }\end{array}$ & Year & $\begin{array}{c}\text { Acres } \\
\text { treated } \\
\text { with com- } \\
\text { mercial } \\
\text { fertilizer }\end{array}$ & $\begin{array}{c}\text { Acres } \\
\text { treated } \\
\text { with } \\
\text { manure }\end{array}$ & $\begin{array}{c}\text { Total } \\
\text { acres } \\
\text { treated }\end{array}$ & $\begin{array}{c}\text { Percent of } \\
\text { county area } \\
\text { (farms only) } \\
\text { treated } \\
\text { with } \\
\text { fertilizer }{ }^{1}\end{array}$ & $\begin{array}{c}\text { Population } \\
\text { of cattle } \\
\text { and calves }\end{array}$ & $\begin{array}{c}\text { Number of } \\
\text { broilers and } \\
\text { other } \\
\text { chickens } \\
\text { sold }\end{array}$ \\
\hline \multirow[t]{2}{*}{$\begin{array}{c}\text { Delaware, } \\
\text { Okla. }\end{array}$} & 67.4 & 23.5 & 282,000 & 2002 & 53,200 & 21,300 & 74,500 & 26 & 74,700 & $37,100,000$ \\
\hline & & & & 2007 & 57,600 & 17,900 & 75,500 & 27 & 83,200 & $48,000,000$ \\
\hline \multirow[t]{2}{*}{$\begin{array}{l}\text { Benton, } \\
\text { Ark. }\end{array}$} & 32.6 & 76.5 & 313,000 & 2002 & 84,700 & 62,800 & 148,000 & 47 & 114,000 & $128,000,000$ \\
\hline & & & & 2007 & 57,800 & 33,800 & 91,600 & 29 & 94,600 & $117,000,000$ \\
\hline
\end{tabular}

${ }^{1}$ Fertilizer application to land other than farms (for example, golf courses or residences) was not included. 

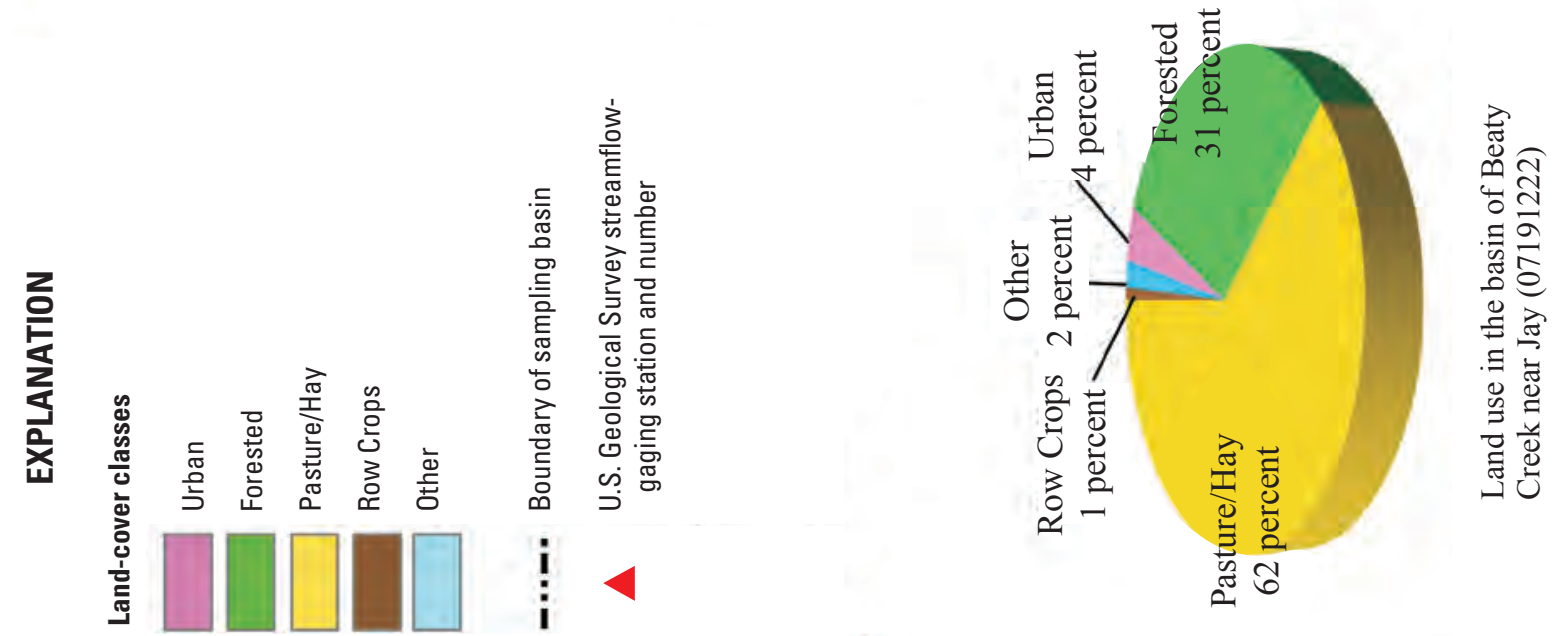

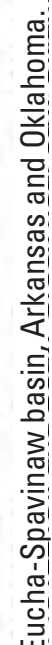

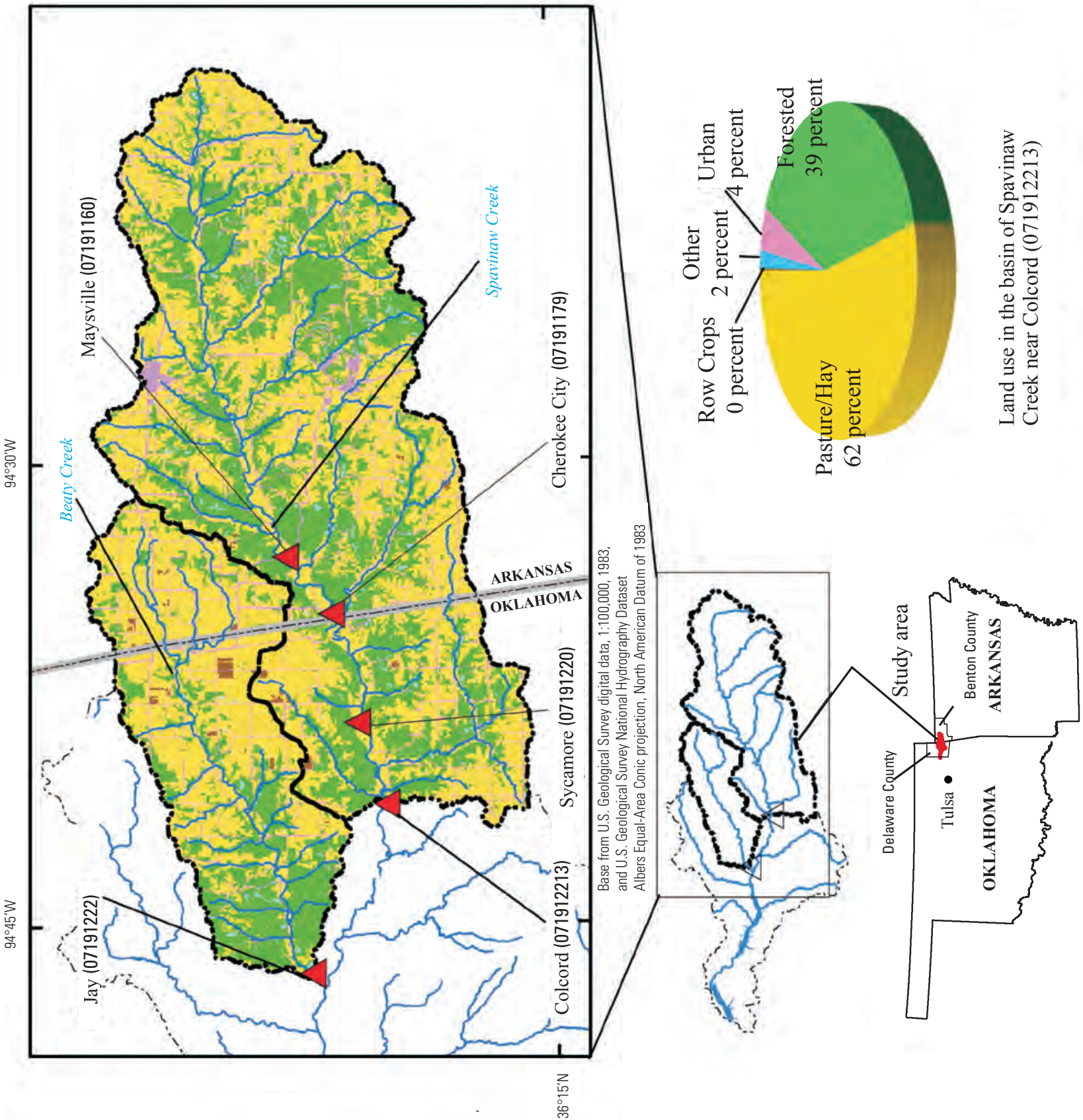

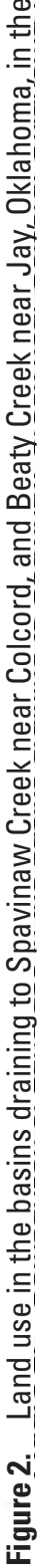




\section{Streamflow in the Eucha-Spavinaw Basin}

The combined drainage areas of Spavinaw Creek near Colcord, Okla., and Beaty Creek near Jay, Okla., account for about 73 percent of the Eucha-Spavinaw basin. Several small tributaries, which are not routinely monitored or sampled, may be additional sources of nitrogen and phosphorus to Lake Eucha and Spavinaw Lake. Streamflow and waterquality data in this report are compared and analyzed in terms of calendar year. Annual mean daily streamflow at stations in the Eucha-Spavinaw basin was computed for calendar years 2002-10. Streamflow was greater in 2004, 2008, and 2009 than in other years (table 2). From 2002-10, there was no streamflow at the Beaty Creek station for 128 days during dry periods.

\section{Methods of Analysis}

\section{Streamflow and Water-Quality Data Collection}

Streamflow data, and nitrogen, phosphorus, and sediment concentration data, and continuously monitored real-time physical water-quality constituent data collected through 2010 were analyzed for this report. All streamflow and water-quality data in this report are available at http://water.usgs.gov/ok/nwis.

Stations were operated and streamflows were measured according to methods described in Rantz and others (1982). Prior to July 2001, only scheduled, monthly water-quality samples were collected at these stations by COT staff, including a few runoff samples. Starting in July 2001 at the Cherokee City, Colcord, and Beaty Creek stations and in December 2001 at the Maysville and Sycamore stations, an average of six runoff water-quality samples were collected annually at these stations by USGS staff. USGS staff collected most of the runoff samples at times of peak flows of each runoff event. COT staff collected water samples at a single point near the center of the stream. USGS staff collected water samples using equal-width increment techniques as described in Edwards and Glysson (1999).

Nitrogen and phosphorus concentrations in this report represent dissolved and particulate components in water because the samples were not filtered. The COT Water Quality Laboratory in Tulsa, Oklahoma, analyzed all water-quality samples using methods described by the U.S. Environmental Protection Agency $(1983,1993)$. U.S. Environmental Protection Agency (USEPA) method code 351.2 was used for analysis of total Kjeldahl nitrogen, USEPA method code 353.2 was used for analysis of nitrate plus nitrite-nitrogen, USEPA method code 365.2 was used for analysis of total phosphorus (U.S. Environmental Protection Agency, 1983, 1993). Total nitrogen concentrations were calculated by adding total Kjeldahl nitrogen (measure of ammonia plus organic nitrogen) and nitrite plus nitrate-nitrogen analyses.
USGS staff installed real-time water-quality monitors at the Colcord station in November 2004 and at the Beaty Creek station in March 2005. The monitors recorded specific conductance, $\mathrm{pH}$, water temperature, turbidity, and dissolved-oxygen concentration. The monitors were initially programmed to record data at hourly intervals at the Colcord station and at half-hour intervals at the Beaty Creek station. The monitor at the Colcord station has collected data readings at half-hour intervals since November 2007 and at 15-minute intervals since March 2010.

Each sensor on the water-quality monitor has a fixed range of operation. The ranges of operation of the specificconductance, $\mathrm{pH}$, water-temperature, and dissolved-oxygen sensors did not exceed those ranges of operation from 2002-10. However, the operational range for turbidity sensors (maximum readings of 1,200 formazin nephelometric units (FNU)) were exceeded during part of the study. At the Colcord station, turbidity values ranging from 1,240 to $1,650 \mathrm{FNU}$ were recorded on June 9 and 19, 2008, and a value of 1,480 FNU was recorded on June 12, 2007. At the Beaty Creek Station, turbidity readings exceeded 1,200 FNU on January 8,2008 . Estimates of nitrogen and phosphorus concentrations from the regression equations described in this report are only valid for the range of sensor values measured from November 2004 and March 2005 through September 2010 at the Colcord and Beaty Creek stations, respectively.

None of the phosphorus or nitrogen data were censored (reported as less than a reporting limit). One sediment sample collected at the Maysville station was censored. In S-LOADEST, model coefficients were calculated using the maximum likelihood method (MLE). When a data set includes censored data, implementation of MLE also is known as tobit regression (Helsel and Hirsch, 1992). For tobit regression, model residuals are assumed to be normally distributed with constant variance.

\section{Quality Assurance}

Quality assurance was achieved through following protocols and procedures described in U.S. Geological Survey (2006) for environmental samples and procedures described in Wagner and others (2006) for the water-quality monitors and collection of quality control (QC) samples. Field blanks and field replicates were collected by the USGS and COT personnel at rates of 3-20 percent of the number of environmental samples annually to document bias and variability in data from collection, processing, shipping, handling, and analyses of samples.

Five field blank samples were collected from the Beaty Creek station - two in 2006 and three in 2010. One blank sample was collected from the Sycamore station in 2007. Total phosphorus concentrations were 0.011 and $0.006 \mathrm{mg} / \mathrm{L}$ in the two field blank samples collected at the Beaty Creek station in 2006 and were nondetectable (less than $0.01 \mathrm{mg} / \mathrm{L}$ ) in the three samples collected from the Beaty Creek station in 2010. Total phosphorus concentration also was nondetectable 


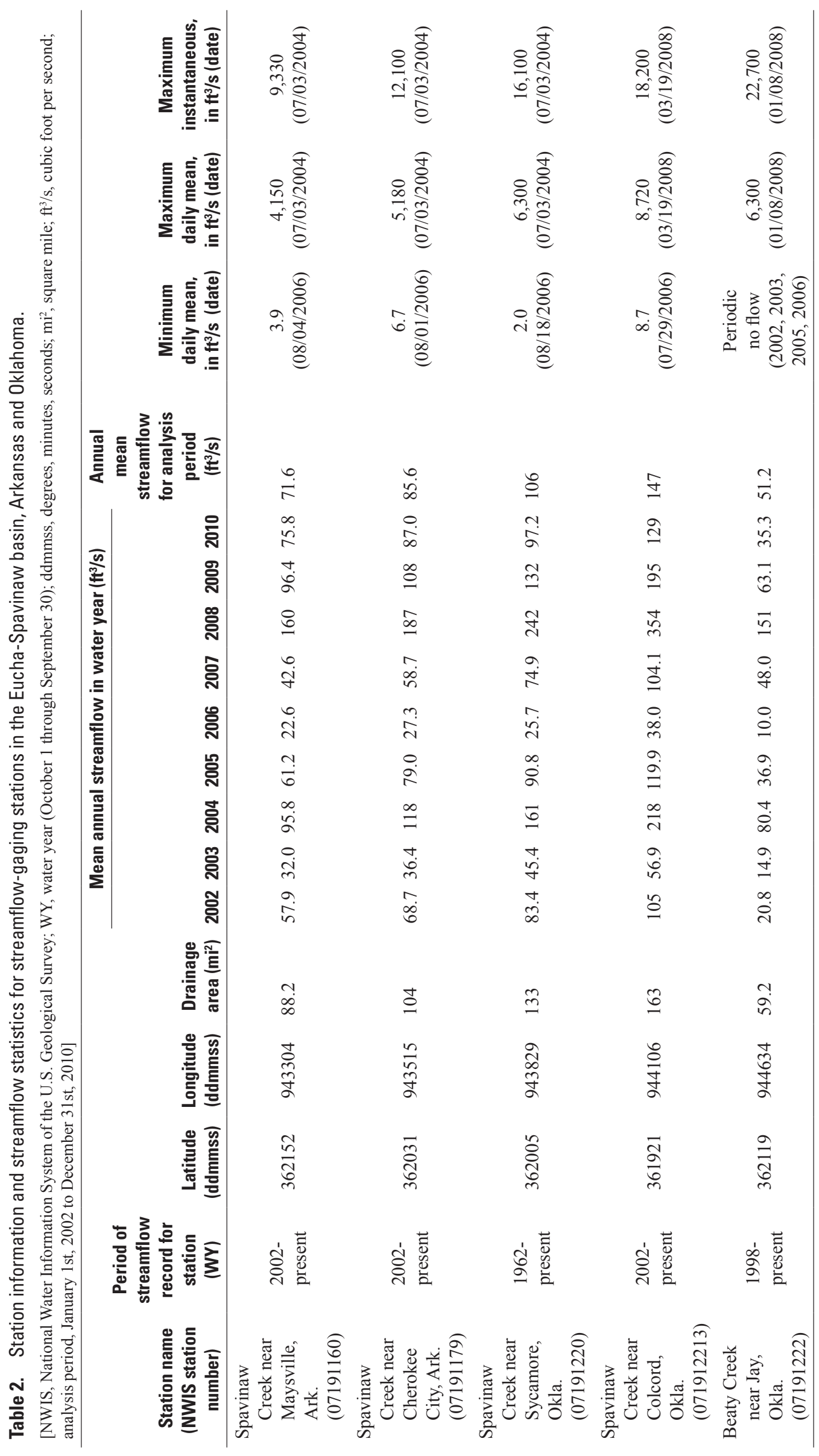


(less than $0.015 \mathrm{mg} / \mathrm{L}$ ) in the blank sample collected at the Sycamore station. Nitrogen concentrations were nondetectable (less than 0.1 to less than $0.41 \mathrm{mg} / \mathrm{L}$ total Kjehldahl nitrogen and less than 0.06 to less than $0.2 \mathrm{mg} / \mathrm{L}$ nitrate plus nitrite) in the five blank samples collected at Beaty Creek. Total Kjehldahl nitrogen was nondetectable (less than $0.58 \mathrm{mg} / \mathrm{L}$ ) but the nitrate plus nitrite-nitrogen concentration was $0.22 \mathrm{mg} / \mathrm{L}$ for the blank sample collected at the Sycamore station. Blank samples indicate that minor contamination may have occurred during sample collection or sample processing and that small bias from potential contamination should be considered in evaluation of the nutrient data in this report. Suspended-sediment concentration was not analyzed in any of the blank samples.

From January 2001 until December 2010, 117 sequential replicate samples were collected. Mean relative percent differences for nitrogen compounds, phosphorus, and sediment ranged from less than 1 percent to 14.5 percent, indicating good reproducibility of data. Relative percent differences between replicate samples were calculated using the equation:

$$
R P D=\mid(E-R) /((E+R) / 2)) \mid * 100 \text { percent }
$$

where

$$
\begin{aligned}
& E \quad \text { is the constituent value of the environmental } \\
& \text { sample and } \\
& R \quad \text { is the constituent value of the } \\
& \text { replicate sample. }
\end{aligned}
$$

Water-quality monitors were inspected, cleaned, and calibrated by USGS personnel at least monthly to maintain calibration. In the event of instrument malfunction or rapidly changing conditions, the monitors were cleaned and calibrated more frequently.

\section{Streamflow Separation}

Base-flow and runoff components of streamflow were separated because base-flow constituent concentrations are more indicative of point sources, and runoff concentrations are more indicative of nonpoint sources in the Eucha-Spavinaw basin. Daily mean streamflow was separated into base-flow and runoff components by using the hydrograph separation program Base-Flow Index (Institute of Hydrology, 1980a, 1980b; Wahl and Wahl, 1995). From 2002-10, percentages of flow that were runoff ranged from 47 to 49 percent at stations on Spavinaw Creek and up to 67 percent at the Beaty Creek station, which are similar to values reported in table 3 of Esralew and Tortorelli (2010). Each day of the study period was designated to be base flow or runoff. Base-flow days are defined as days that base flow contributed greater than or equal to 70 percent of total flow; runoff days were defined as days that runoff contributed greater than 30 percent of total flow.

\section{Development of Regression Equations to Estimate Concentrations and Loads}

Esralew and Tortorelli (2010, p. 15-24) summarized nitrogen and phosphorus concentrations for the period 2002-09, and an assumption was made that the results from that study did not change based on an additional year of data. Because sediment data were not previously analyzed, a brief analysis of characteristics of sediment concentrations, loads, and yields between stations is included in this report. The Kruskal-Wallis test (Helsel and Hirsch, 1992) was used to determine the statistical significance of differences in sediment concentrations among stations. Sediment analyses were not done for monthly samples collected by COT staff, therefore, only 18 base-flow sediment samples were collected by USGS staff. Linear regression was used to evaluate relations between nitrogen and phosphorus loads (dependent variables) and streamflow and time variables (independent variables). Methods for determination of loads using regressions based on flow, time, and seasonality used the S-LOADEST program (D. Lorenz, U.S. Geological Survey, written commun., 2006) as described in Tortorelli $(2006,2008)$ and Esralew and Tortorelli (2010). In this report, the regression technique used to estimate daily mean load from streamflow, time, and seasonality is referred to as the $\mathrm{DM}_{\mathrm{L}}$ regression. Load computations using $\mathrm{DM}_{\mathrm{L}}$ regressions are compared with load computations from regressions used to estimate instantaneous

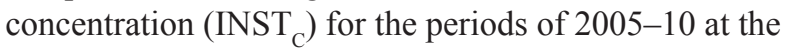
Colcord station and 2006-10 at the Beaty Creek station.

To investigate whether the coefficients on the models and resulting load estimates changed substantially from those published in Esralew and Tortorelli (2010) with an additional year of data, models were rerun to estimate nitrogen and phosphorus load at all five stations using data from 2002-10. For all rerun models, the mean and median of all computed daily loads and mean annual total loads changed by no more than 2 percent. Because these differences were assumed to have negligible effect on the load computation for 2002-10 and remain consistent with the previous publication, loads computed for this report used the same models published in Esralew and Tortorelli (2010).

Separate linear regression models were developed in S-LOADEST for estimation of sediment for the period 2002-10 because loading of this constituent was not computed or analyzed for the Eucha-Spavinaw basin in previous publications. The "best" model for estimation of sediment load selected using S-LOADEST was selected for each station.

Annual loads are computed by summing all daily mean loads for the year. The daily load values generated by S-LOADEST were separated into base-flow and runoff sample sets according to the number of base-flow days and the number of runoff days for the entire sampling period. Nitrogen and phosphorus yields for the study period at each station were calculated by dividing mean annual nitrogen and phosphorus loads by drainage area (table 2). 
All of the estimates in this report have some uncertainty. The uncertainty of the $\mathrm{DM}_{\mathrm{L}}$ regressions need to be considered if the equations are to be used to estimate future loads. The coefficient of determination $\left(\mathrm{R}^{2}\right)$ and root mean square error (RMSE) give indications of the proportion of variability in a data set accounted for by a regression model and uncertainty (table 3 ). Uncertainty of daily load estimates also was determined from the S-LOADEST software using a 90-percent prediction interval (Helsel and Hirsch, 1992). Error computation methods used in this report are described in greater detail in Cohn and others (1989) and Gilroy and others (1990). Prediction intervals for annual loads were summed for the upper and lower 90-percent prediction intervals for each daily estimate.

A method of estimating concentrations and loads of water-quality constituents in real time was applied in Christensen and others (2008) to estimate nitrogen and phosphorus in the Eucha-Spavinaw basin using data collected from 2004-07. In this report, those regressions were updated using data through 2010 using the same methods, and sediment regressions also were developed. Similar to the $\mathrm{DM}_{\mathrm{L}}$ regression, nitrogen-, phosphorus-, and sedimentconcentration data from water-quality samples (dependent variables) and physical water-quality constituents collected from real-time water-quality monitors (independent variables) at Spavinaw Creek and Beaty Creeks were used to develop regression equations to estimate instantaneous concentrations of nitrogen, phosphorus, and sediment when sample data were not available. For the remainder of this report, regressions developed with this technique are referred to as $\mathrm{INST}_{C}$ regressions. Unlike $\mathrm{DM}_{\mathrm{L}}$ regressions, time was not considered a variable in the INST ${ }_{C}$ regressions in Christensen and others (2008) so that these regressions could be used to estimate future concentrations in real time. However, if time is a significant variable in the $\mathrm{INST}_{\mathrm{C}}$ regression for a given constituent, that significance may indicate a trend in constituent concentration with time and may bias future INST $_{C}$ estimates. To be consistent with methods used in previous reports, time, in this report, was not included as an independent variable, but error residuals in the INST $_{C}$ regressions were checked for trends with time using Kendall's tau trend test (Kendall, 1975). If significant trends in error residuals were detected, later subperiods were used in the regression to eliminate time as a significant variable so that future estimates using INST $_{C}$ regressions were more representative of recent conditions. INST $_{C}$ estimates can be used to compute daily loads, annual loads, and yields of nitrogen and phosphorus. Instantaneous concentration and instantaneous streamflow correspond to a single moment in time as opposed to an average or sum. Loads can be computed from the $\mathrm{INST}_{\mathrm{C}}$ regression estimates of instantaneous concentration by computing instantaneous load for each estimate and summing these loads for each day and over the year.

Instantaneous concentration and load could not be estimated using the $\mathrm{INST}_{\mathrm{C}}$ regression for all days because of missing water-quality-monitor records. For days in which instantaneous concentrations could not be measured or interpolated for all time intervals, daily load estimates and prediction intervals from the $\mathrm{DM}_{\mathrm{L}}$ regression were substituted if: (a) less than one-half of instantaneous INST $_{C}$ estimates were available for a day and streamflow and water-quality conditions were not substantially variable, or (b) more than one-half of instantaneous INST $_{C}$ estimates were available but streamflow and water-quality conditions were substantially variable (for example, if monitor measurements were missing during a storm). Uncertainties of $\mathrm{DM}_{\mathrm{L}}$ estimates also were determined from the S-LOADEST software using a 90-percent prediction interval (Helsel and Hirsch, 1992). Error computation methods used in this report are described in greater detail in Cohn and others (1989), and Gilroy and others (1990). The 90-percent prediction interval was computed for all estimates for this report for evaluation and discussion purposes and for comparison to ranges from the alternate equations regardless of whether streamflow or water-quality constituents used to compute the estimate were within the range of streamflow used to develop the regression. Therefore, annual load estimates and 90-percent prediction intervals presented in this report may contain substantial uncertainty because the total annual load and annual prediction interval computation contained some instantaneous or daily estimates that were extrapolated. The SEP contains the effects of random error in addition to the error because of the model calibration (parameter uncertainty) and increases substantially when independent variables for the estimate are outside the range of independent variables used to develop the regression. The SEP and the 90-percent prediction interval for estimated instantaneous concentrations were computed using S-LOADEST software. Uncertainty of streamflow data used to estimate daily load could not be quantified for this report because uncertainty information about daily streamflow data is not readily available or feasible to calculate.

The uncertainty of the $\mathrm{INST}_{\mathrm{C}}$ regressions needs to be considered if the equations are used to estimate future concentrations or nitrogen and phosphorus loads. The $\mathrm{R}^{2}$, RMSE, standard error of prediction (SEP), prediction intervals, and Duan's smearing bias-correction factor (Duan, 1983) give indications of uncertainty. Similar to the $\mathrm{DM}_{L}$ regressions, uncertainties of instantaneous load estimates were determined using a 90-percent prediction interval (Helsel and Hirsch, 1992) and were extrapolated for some estimates in which independent variables exceeded the variables used to develop the regressions. The SEP was used to compute the 90-percent prediction interval for each concentration estimate from the $\mathrm{INST}_{\mathrm{C}}$ regressions.

\section{Comparison of Differences in Regression-Based Daily Load Estimates}

Data used to develop the $\mathrm{DM}_{\mathrm{L}}$ and $\mathrm{INST}_{\mathrm{C}}$ regression equations were compared graphically rather than statistically 
because tests, such as the Mann-Whitney test, require that data be from independent populations (Helsel and Hirsch, 1992). Graphical comparisons of nitrogen, phosphorus, and sediment concentrations used to generate regressions were made for data collected from 2002-10 (used in the $\mathrm{DM}_{\mathrm{L}}$ regression equations) and collected from 2004-10 and 2005-10 for the Colcord and Beaty Creek stations, respectively (used in the $\mathrm{INST}_{\mathrm{C}}$ regression equations).

Estimates of annual loads at the Colcord and Beaty Creek stations obtained using the $\mathrm{DM}_{\mathrm{L}}$ and $\mathrm{INST}_{\mathrm{C}}$ regression methods were compared using bar graphs for the period 2006-10 and load-duration curves for the period November 2004 through December 2010 for the Colcord station and March 2005 through December 2010 for the Beaty Creek station. Load-duration curves were developed using in the Hydrostat program (C. Konrad, U.S. Geological Survey, written commun, 2007). Load-duration curves are graphical representations of the percentage of the time that daily load is equaled or exceeded during a specified period. Load-duration curves were developed for nitrogen, phosphorus, and sediment loads for each station and regression method to visually identify differences in daily load between the regression methods at different probabilities of exceedance.

For this report, a negative relative percent difference indicates that loads from a $\mathrm{DM}_{\mathrm{L}}$ regression were greater than loads from the $\mathrm{INST}_{\mathrm{C}}$ regression. The two-sided Wilcoxon signed-rank test (Wilcoxon, 1945; referred to in this report as the "signed-rank test") was used to determine if there were significant differences in daily mean loads computed using the two regression methods for data collected at the Colcord and Beaty Creek stations. Comparisons were made using daily loads from different flow conditions to see if differences varied with runoff or base-flow conditions. For this report, if the two-sided test for any given station, constituent load, and flow type was statistically significant at a p-value of 0.05 , then a one-sided signed-rank test was done in which the null hypothesis was that the median difference between paired observations was greater than zero, indicating that daily loads estimated from the $\mathrm{DM}_{\mathrm{L}}$ regression probably are greater than daily loads estimated from the INST ${ }_{C}$ regression. Differences in load were considered statistically greater for daily load estimated from the $\mathrm{DM}_{\mathrm{L}}$ regression at a $\mathrm{p}$-value of 0.05 . Differences in load were considered statistically greater for daily loads computed from INST $_{C}$ regressions at a p-value of 0.95 . To avoid bias for comparison of days when daily load estimates from the $\mathrm{DM}_{\mathrm{L}}$ regression was substituted for daily load estimates from the INST ${ }_{C}$ regression, only days where daily load estimates from INST ${ }_{C}$ regressions could be made were used for the signed-rank test.

\section{Evaluation of Differences in Fit}

Fit of the $\mathrm{DM}_{\mathrm{L}}$ and $\mathrm{INST}_{\mathrm{C}}$ regressions in this report cannot be directly compared using $\mathrm{R}^{2}$ and RMSE because the $\mathrm{DM}_{\mathrm{L}}$ regressions were used to estimate daily mean load, whereas, $\mathrm{INST}_{\mathrm{C}}$ regressions were used to estimate constituent concentration converted to a daily load. A bias correction factor was applied for each daily load estimate developed from the $\mathrm{DM}_{\mathrm{L}}$ regressions, referred to as the minimum variance unbiased estimate (MVUE) (Bradu and Mundlak, 1970). The smearing bias-correction factor (Duan, 1983) was used to correct underestimation resulting from retransformation of regression-estimated concentrations for the $\mathrm{INST}_{\mathrm{C}}$ regressions because that method was used in previous investigations (Christensen and others, 2008). The benefit of Duan's smearing coefficient is this coefficient is easily applied to all estimates, compared to the MVUE bias correction procedure used in development of the $\mathrm{DM}_{\mathrm{L}}$ regression in S-LOADEST, which requires a different factor for each daily estimate and is computationally more complex than Duan's smearing coefficient. A comparison of Duan's smearing coefficient and the MVUE bias correction procedure was beyond the scope of this report. The $\mathrm{R}^{2}$ and RMSE values of these regressions do not have identical units, and different regression methods and bias correction procedures were used, which also preclude direct comparisons. Although the fit from these regression methods could not be directly compared, comparison of the size of the prediction intervals can give an indication of the general reliability of these regression estimates under various streamflow and water-quality conditions. Graphs showing the 90-percent confidence intervals for both methods were developed for selected periods of daily measurements to show examples of comparative uncertainty between regression methods.

For this report, alternate regressions to estimate concentration using the independent variables of the $\mathrm{DM}_{\mathrm{L}}$ regressions were computed to compare accuracy between regression methods because the difference in variance could be more easily observed and compared between regressions without the notable influence of streamflow on loads. The purpose of comparisons between $\mathrm{DM}_{\mathrm{L}}$ and $\mathrm{INST}_{\mathrm{C}}$ regressions were to evaluate differences and potential biases from regression methods used in previous reports (Tortorelli, 2006; Tortorelli, 2008; Christensen and others 2008; Esralew and Tortorelli, 2010). Evaluation of regression methods that use physical water-quality constituent values and streamflow to estimate instantaneous load compared to loads computed from estimated instantaneous concentrations from INST $_{\mathrm{C}}$ regressions presented in this report may be beneficial for future improvements to regression methods.

\section{Methods of Analysis of Temporal Trends in Concentration}

Trends in concentrations of nitrogen (nitrate plus nitritenitrogen and total nitrogen), phosphorus, and sediment with time were evaluated for data collected at the five stations from 2002-10 to determine whether BMPs and wastewater effluent affected concentrations of those constituents in this basin. The S-Plus statistical program S-Estimate Trend (S-ESTREND) (Schertz and others, 1991) based on the Seasonal Kendall tau 
(Kendall, 1975) or Kendall-Thiel tests (Helsel and Hirsch, 1992) was used for analysis of water-quality trends. The small number of suspended-sediment analyses during baseflow conditions was insufficient to determine temporal trends of suspended-sediment concentrations at base-flow conditions. Kendall's tau test (Kendall and Gibbons, 1990) is a nonparametric statistical test used to indicate the likelihood of upward or downward trends in data with time and is effective for identifying trends in streamflow because high or low data outliers and skewness in the dataset do not affect the test (Helsel and Hirsch, 1992). The tau is an indicator of the relative number of data pairs with positive or negative differences:

$$
t=((P-M) /(n(n-1) / 2)
$$

where
$P \quad$ is the number of increases, and
$M \quad$ is the number of decreases between data pairs.

The Kendall-Thiel test is similar to the Seasonal Kendall tau test but has no seasonal correction (Helsel and Hirsch, 1992). A trend slope, which is a measure of the magnitude and direction of a trend, was computed using the Sen Slope Estimator (Sen, 1968; Helsel and Hirsch, 1992). The Seasonal Kendall tau test reduces the effects that season has on streamflow and concentration by limiting comparisons to data from the same seasons and adjusting for variations in streamflow. Seasonal Kendall tau tests also were performed on base-flow and runoff datasets to compare trends associated with different flow regimes. Trends based on flow regime may provide information regarding factors associated with the trend, for example, base-flow concentrations generally are more indicative of point sources (or groundwater quality), and runoff concentrations are more indicative of nonpoint sources. To compensate for variations in data density resulting from inconsistencies in sample collection during base flow and runoff, data were divided into four seasons: spring (March-May), summer (June-August), autumn (SeptemberNovember), and winter (December-February). Sediment trend analysis could only be applied to samples collected during runoff and seasons could not be analyzed because of limited data. The Seasonal Kendall or Kendall's tau trend test also was applied to error residuals and time. Significant trends in flow-adjusted concentrations determined by $p$-values of the Seasonal Kendall tau test would indicate that factors other than variation of streamflow may have caused changes in concentration, such as application of BMPs or changes in nitrogen and phosphorus contribution from wastewater treatment.

The Seasonal Kendall tau test was used to test the significance of trends in water quality with time. Factors other than time can affect water quality. A statistically significant correlation between constituent concentration and streamflow may obscure underlying trends with time or other variables. Flow-adjustment techniques were used to remove the effects of streamflow variability on concentrations by computing a time series of flow-adjusted concentrations (Helsel and Hirsch, 1992). Flow-adjusted concentrations are the error residuals from a regression between concentration and streamflow at the time of sample collection (Helsel and Hirsch, 1992, p. 331-335).

A LOESS regression (Cleveland and Devlin, 1988) was used to describe the relation between streamflow and constituent concentration. This method is robust because use of distance and residual-weighting functions with weighted least squares avoids use of complex data transformations, and the influence of outliers in fitting a smooth line to the data is minimized (Schertz and others, 1991, p. 24). Natural logarithm transformation of each annual streamflow parameter and annual precipitation were used to improve the fit of the LOESS regression (and are referred to as a "log-log LOESS" regressions). Log-log LOESS regressions were used if streamflow was significantly ( $\mathrm{p}$-value less than or equal to 0.05 ) correlated to constituent concentration based on a partial t-test (Helsel and Hirsch, 1992) evaluating the correlation between streamflow at the time of sample collection and constituent concentration. If there was no statistically significant correlation between streamflow and constituent concentration, flow adjustment for that station, constituent, and flow type was not calculated.

\section{Streamflows, Loads, and Instantaneous Concentrations in the Eucha-Spavinaw Basin, 2002-10}

During 2002-10, the smallest mean annual streamflows at the five stations occurred in 2006 (table 2), although 2005 was the year with the least amount of precipitation from 2002-10. The maximum peak flows for this period occurred in 2004 at the Maysville, Cherokee City, and Sycamore stations and in 2008 at the Colcord and Beaty Creek stations. Maximum daily mean streamflow was substantially less than maximum instantaneous streamflow at all stations.

\section{Water-Quality Data Used to Develop Regression Equations}

Data used to develop regressions were collected during varying climatic conditions that affected streamflow and water quality. Summaries of significant differences in nitrogen and phosphorus concentrations are from Esralew and Tortorelli (2010).

\section{Nitrogen and Phosphorus Concentrations}

Nitrogen concentrations generally increased with increasing streamflow, indicating substantial contribution of 
nitrogen from nonpoint sources. Nitrogen concentrations were significantly greater (p less than or equal to 0.05 ) in runoff samples than in base-flow samples collected at the Maysville, Cherokee City, Colcord, and Beaty Creek stations.

Nitrogen concentrations in all samples from Spavinaw Creek significantly increased (p less than or equal to 0.05 ) downstream from the Maysville station to the Sycamore station and significantly decreased from the Sycamore station downstream to the Colcord station. Nitrogen concentrations in samples from Beaty Creek were significantly less than those in Spavinaw Creek (Esralew and Tortorelli, 2010). Nitrogen concentrations were significantly greater in samples collected during winter and spring than in summer or autumn at most stations, possibly because of lesser uptake of nitrogen and phosphorus by aquatic plants in winter, application of fertilizers in spring, and greater runoff in spring (Esralew and Tortorelli, 2010).

Phosphorus concentrations in samples collected at the Beaty Creek and Maysville stations were significantly less than those in samples collected at the other Spavinaw Creek stations and were smallest at the Maysville station (Esralew and Tortorelli, 2010). Except for the Cherokee City station, where water quality was affected by discharge from the Decatur wastewater-treatment plant, phosphorus concentrations were significantly greater ( $p$ less than or equal to 0.05 ) in runoff samples than in base-flow samples. The larger concentration of phosphorus associated with runoff indicates primarily nonpoint sources of phosphorus.

Phosphorus concentration in base-flow samples collected from Spavinaw Creek significantly increased ( $p$-value less than or equal to 0.05 ) from the Maysville station to the Cherokee City station, perhaps because of effluent discharged from the Decatur wastewater-treatment plant between those stations. Phosphorus concentration significantly decreased downstream from the Cherokee City station to the Colcord station, perhaps caused by sorption into streambed sediments or aquatic plants. Phosphorus concentrations did not differ significantly by season except at the Maysville station, where spring and summer concentrations were greater than autumn and winter concentrations (Esralew and Tortorelli, 2010).

Boxplots showing nitrogen and phosphorus concentrations from all samples used to develop the $\mathrm{DM}_{\mathrm{L}}$ regressions for the period 2002-10 for all five stations, and samples used to develop the INST $_{C}$ regressions for the period 2004-10 for the Colcord and Beaty Creek stations are shown in figures 3-4. Nitrogen and phosphorus concentrations used in the $\mathrm{DM}_{\mathrm{L}}$ regressions were not substantially different than those concentrations used in the $\mathrm{INST}_{\mathrm{C}}$ regressions for the Colcord or Beaty Creek stations.

\section{Sediment Concentrations}

Unlike nitrogen and phosphorus concentrations, suspended-sediment concentrations did not differ significantly by season or between stations ( $\mathrm{p}$-value less than or equal to 0.05 ) based on a Kruskal-Wallis test. Boxplots showing distributions of suspended-sediment concentrations used to develop the $\mathrm{DM}_{\mathrm{L}}$ regression for the period 2002-10 for all five stations and the $\mathrm{INST}_{\mathrm{C}}$ regression for the period 2005-10 for the Colcord and Beaty Creek stations are shown in figure 5. Suspended-sediment concentrations used in the $\mathrm{DM}_{\mathrm{L}}$ regressions were not substantially different than those concentrations used in the $\mathrm{INST}_{\mathrm{C}}$ regressions for the Beaty Creek station.

\section{Estimated Loads and Yields of Nitrogen, Phosphorus, and Suspended Sediment, 2002-10}

The best-fit $\mathrm{DM}_{\mathrm{L}}$ regressions were different for each constituent and station (table 3 ). Nitrogen and phosphorus equations were the same as those determined in Esralew and Tortorelli (2010). Consistency and details about the regression selection are described in more detail in that report. Seasonal variables were not statistically significant estimators of daily sediment load for any of the stations, and negative linear time (T) was a statistically significant estimator of daily sediment load at the Maysville, Sycamore, and Beaty Creek stations, indicating significant decreases in sediment concentration with time.

Nitrogen and phosphorus $\mathrm{DM}_{\mathrm{L}}$ regressions had higher $\mathrm{R}^{2}$ values, indicating better fits to the data than the sediment $\mathrm{DM}_{L}$ regressions (table 3). Uncertainty in sediment $\mathrm{DM}_{\mathrm{L}}$ regression models is associated with substantial variability in sampled sediment concentrations, even for replicates, and by a poorer correlation between sediment concentration and streamflow as compared to nitrogen and phosphorus concentrations.

\section{Nitrogen Loads and Yields}

Mean annual total nitrogen loads ranged from 354,000 to $1,290,000$ pounds per year (lbs/yr) as estimated from the $\mathrm{DM}_{\mathrm{L}}$ regressions from 2002-10 (table 4). Nitrogen loads and yields were similar to those reported in Esralew and Tortorelli (2010), indicating that the 2010 annual load was not a substantial outlier compared to those for 2002-09. Estimated mean annual nitrogen total loads (the sum of base-flow and runoff loads) were substantially greater at Spavinaw Creek stations than at the Beaty Creek station. Annual total baseflow and runoff loads increased in Spavinaw Creek in a downstream direction from the Maysville station (table 4, fig. 6).

The runoff component of the mean annual nitrogen load at the Spavinaw Creek stations ranged from 66 to 71 percent and increased with larger drainage areas (table 4). About 87 percent of the mean annual nitrogen load for Beaty Creek was from runoff (table 4). The runoff components of nitrogen were about 1 to 2 percent less for 2002-10 than those reported in Esralew and Tortorelli (2010) for 2002-09. 


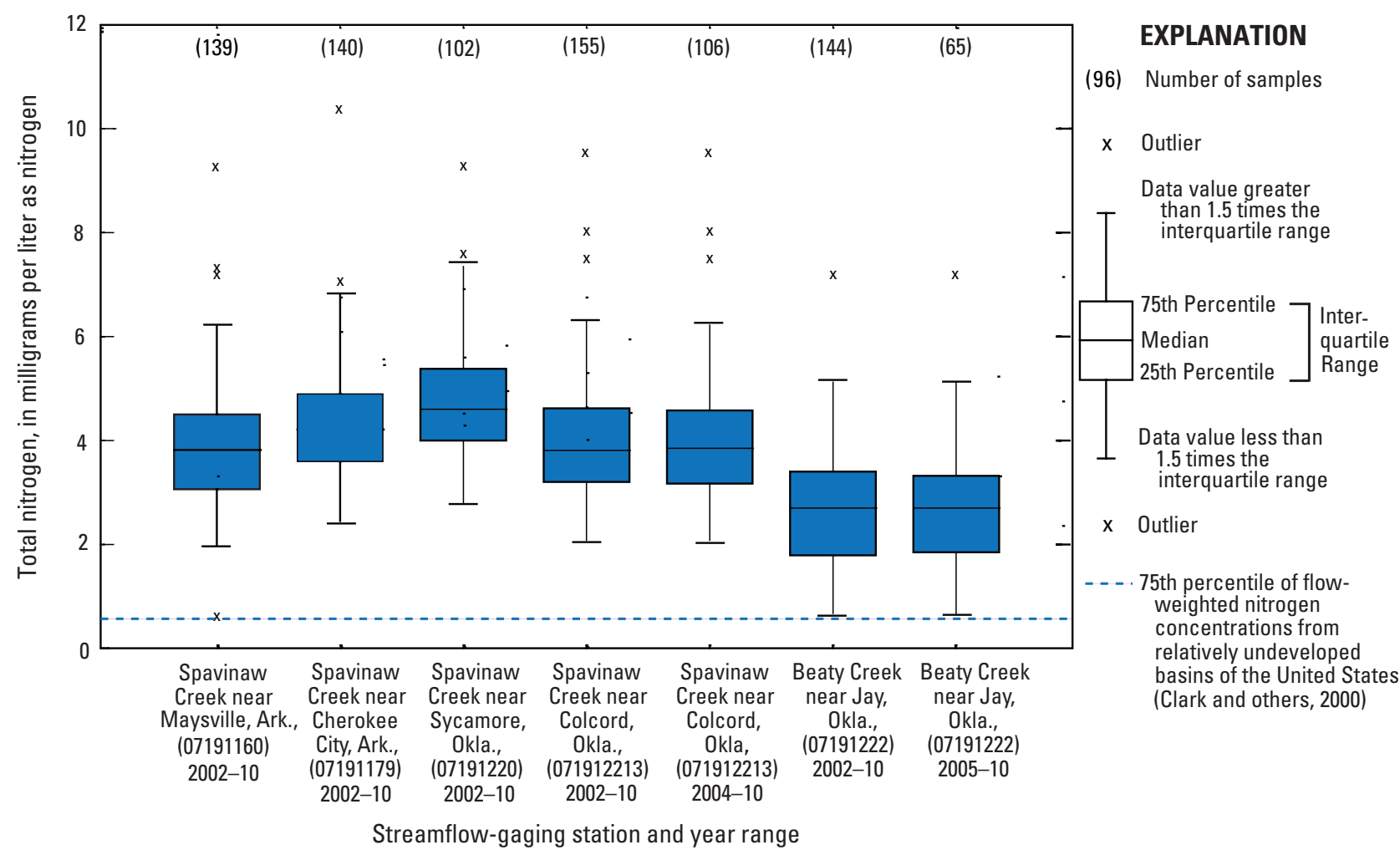

Figure 3. Distributions of total nitrogen concentrations in water samples collected from different time periods at streamflow-gaging stations in the Eucha-Spavinaw basin, Arkansas and Oklahoma.

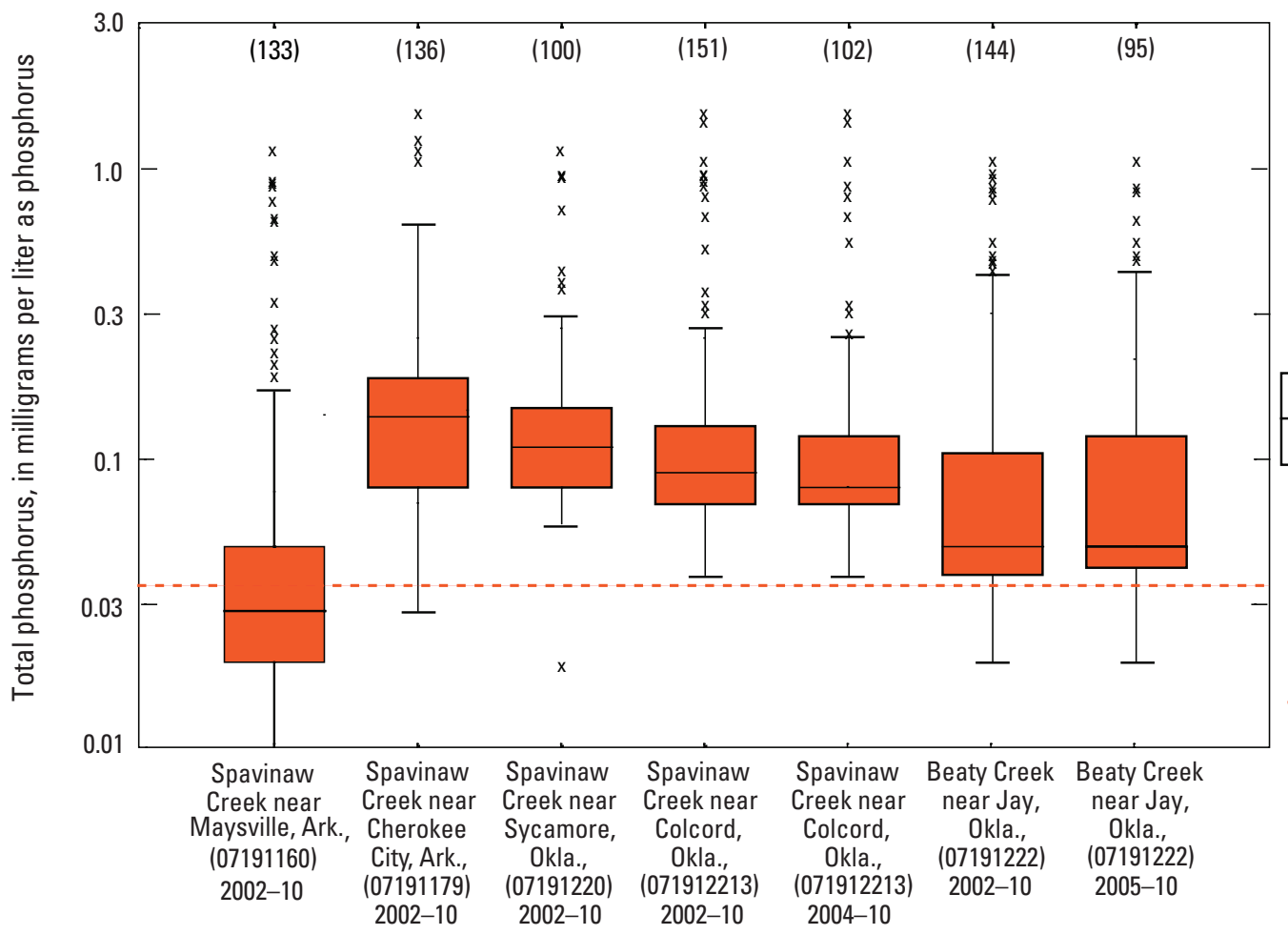

\section{EXPLANATION}

(95) Number of samples

x Outlier

Data value greater than 1.5 times the interquartile range
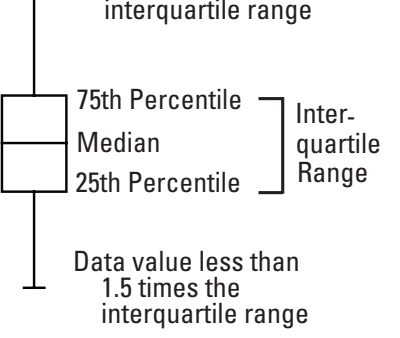

$x$ Outlier

- - - 75th percentile flowweighted phosphorus concentrations from relatively undeveloped basins of the United States (Clark and others, 2000)

Streamflow-gaging station and year range

Figure 4. Distributions of total phosphorus concentrations in water samples collected from different time periods at streamflow-gaging stations in the Eucha-Spavinaw basin, Arkansas and Oklahoma. 


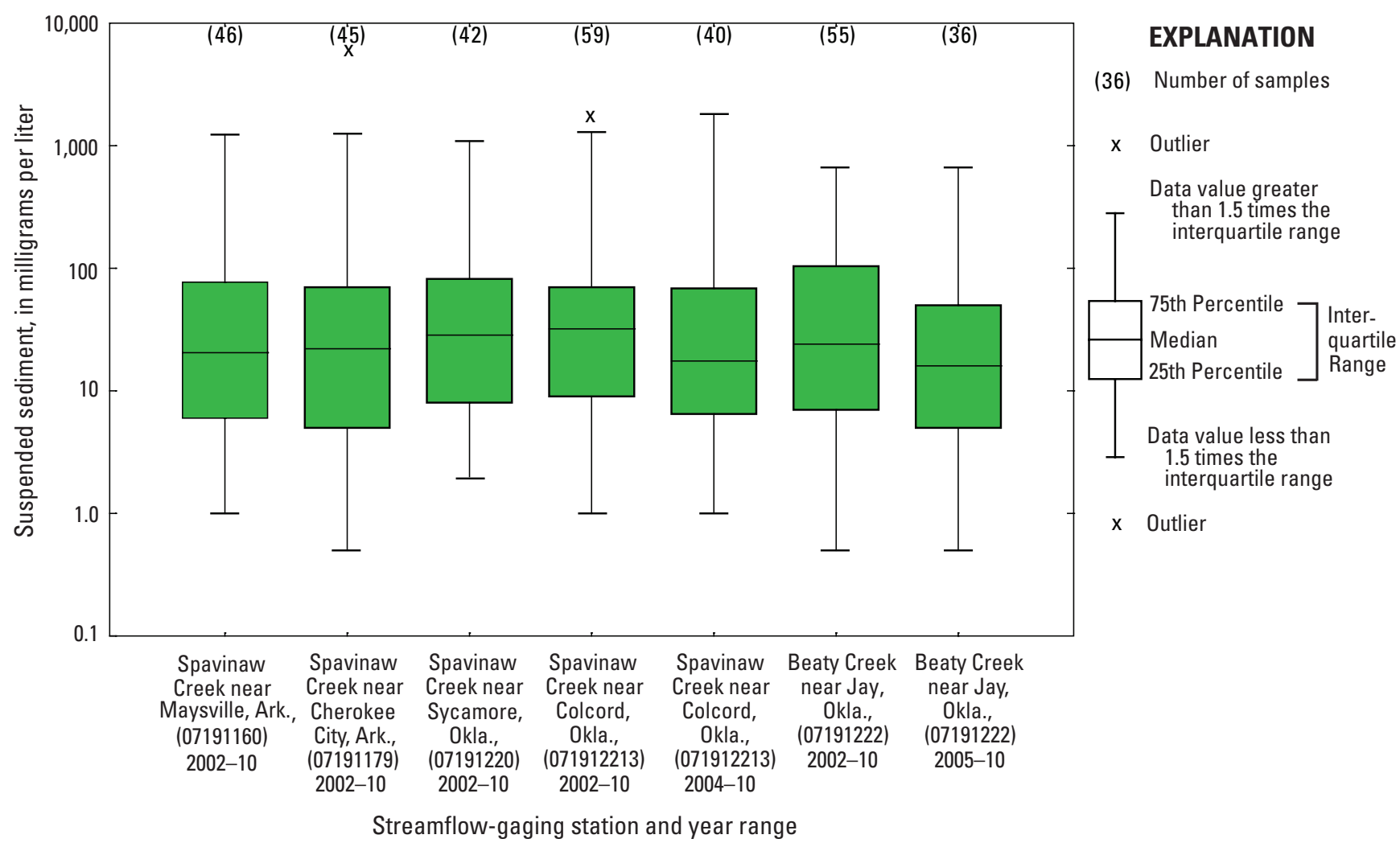

Figure 5. Distributions of suspended-sediment concentrations in water samples collected from different time periods at streamflowgaging stations in the Eucha-Spavinaw basin, Arkansas and Oklahoma.

Mean annual total nitrogen yields at the stations ranged from 5,980 to 7,890 pounds per year per square mile $\left(\mathrm{lbs} / \mathrm{yr} / \mathrm{mi}^{2}\right)$ and generally increased in a downstream direction in the Spavinaw Creek basin (table 4). The base-flow yields were less at the Beaty Creek station than at the Maysville station. Beaty Creek mean annual runoff yields of nitrogen, however, were similar to most runoff yields in the Spavinaw Creek basin (table 4) and more than the runoff yield at the Maysville station. Possible explanations for the difference in base-flow yield between Beaty and Spavinaw Creeks may be a greater influence of groundwater on streamflow and greater nitrogen base-flow concentrations in Spavinaw Creek (downstream from the Maysville station) than in Beaty Creek (table 4), and, therefore, a greater percentage of nitrogen load delivered during base flow for Spavinaw Creek (table 4, Esralew and Tortorelli, 2010).

\section{Phosphorus Loads and Yields}

Mean annual total phosphorus loads ranged from 25,000 to $66,900 \mathrm{lb} / \mathrm{yr}$ from $2002-10$ as estimated from the $\mathrm{DM}_{\mathrm{L}}$ regressions. Phosphorus loads and yields were slightly less than those reported in Esralew and Tortorelli (2010), indicating that the 2010 annual load was not substantially different than those for the period 2002-09 (fig. 7).

Estimated mean annual total phosphorus, base-flow, and runoff loads were substantially greater for at least half of the Spavinaw Creek stations than the Beaty Creek station, primarily because of greater streamflow at the Spavinaw Creek stations (Esralew and Tortorelli, 2010). Annual total, base-flow, and runoff loads generally increased in Spavinaw Creek in a downstream direction from the Maysville station (table 4), with the exception of the Cherokee City station, at which phosphorus base-flow load was greater than at the Sycamore station. 
Table 3. Regression equations for estimating daily mean loads (DMLs) of total nitrogen, total phosphorus, and sediment using streamflow, seasonality, and time at streamflow-gaging stations in the Eucha-Spavinaw basin, Arkansas and 0klahoma, 2002-10. $\left[\mathrm{ln}\right.$, natural logarithm; $\mathrm{DML}_{\mathrm{TN}}$, total nitrogen daily mean load in pound per day; $\mathrm{DML}_{\mathrm{TP}}$, total phosphorus daily mean load in pound per day; $\mathrm{DML}_{\mathrm{Sed}}$, suspended sediment daily load in pound per day; $\mathrm{Q}$, mean daily streamflow in cubic foot per second; $\mathrm{T}$, decimal time, time parameter in decimal years; sin, sine; cos, cosine; SS, seasonality parameter; $\mathrm{R}^{2}$, coefficient of determination, *from Esralew and Tortorelli, 2010]

\begin{tabular}{|c|c|c|c|c|}
\hline $\begin{array}{l}\text { Number of } \\
\text { observations }\end{array}$ & Daily mean load regression equation & $\begin{array}{c}\text { Estimated } \\
\text { residual } \\
\text { variance } \\
\text { (pounds } \\
\text { per day) }\end{array}$ & $\begin{array}{c}\text { Root mean } \\
\text { square error } \\
\text { (pounds per } \\
\text { day) }\end{array}$ & $\begin{array}{c}\mathbf{R}^{2} \\
\text { (percent) }\end{array}$ \\
\hline \multicolumn{5}{|c|}{ Spavinaw Creek near Maysville, Ark. (07191160) } \\
\hline $139 *$ & $\begin{array}{l}\ln \left(\mathrm{DML}_{\mathrm{TN}}\right)=8.09+1.13 *(\ln \mathrm{Q}-4.93)-0.018 *(\ln \mathrm{Q}-4.93)^{2}-0.005 *(\mathrm{~T}-2005.92) \\
\quad+0.002 *(\mathrm{~T}-2005.92)^{2}-0.013 * \sin \mathrm{SS}+0.14 * \cos \mathrm{SS}\end{array}$ & 0.048 & 0.219 & 98.3 \\
\hline $133^{*}$ & $\begin{array}{l}\ln \left(\mathrm{DML}_{\mathrm{TP}}\right)=3.63+1.54 *(\ln \mathrm{Q}-4.93)+0.159 *(\ln \mathrm{Q}-4.93)^{2}+0.023 *(\mathrm{~T}-2005.93) \\
\quad-0.089 * \sin \mathrm{SS}-0.135 * \cos \mathrm{SS}\end{array}$ & 0.200 & 0.447 & 96.3 \\
\hline 46 & $\ln \left(\mathrm{DML}_{\mathrm{Sed}}\right)=9.79+2.02 *(\operatorname{lnQ}-3.28)-0.263 *(\ln \mathrm{Q}-3.28)^{2}-0.13 *(\mathrm{~T}-2006.11)$ & 0.775 & 0.880 & 93.5 \\
\hline \multicolumn{5}{|c|}{ Spavinaw Creek near Cherokee City, Ark. (07191179) } \\
\hline 45 & $\ln \left(\mathrm{DML}_{\mathrm{Sed}}\right)=10.3+2.13 *(\ln \mathrm{Q}-3.53)-0.195 *(\ln \mathrm{Q}-3.23)^{2}$ & 1.52 & 1.231 & 88.1 \\
\hline \multicolumn{5}{|c|}{ Spavinaw Creek near Sycamore, Okla. (07191220) } \\
\hline $102 *$ & $\begin{array}{l}\ln \left(\mathrm{DML}_{\mathrm{TN}}\right)=8.78+1.07 *(\operatorname{lnQ}-5.41)+0.003 *(\operatorname{lnQ}-5.41)^{2}-0.003 *(\mathrm{~T}-2005.92)^{2} \\
\quad+0.012 * \sin \mathrm{SS}+.169 * \cos \mathrm{SS}\end{array}$ & 0.021 & 0.144 & 99.1 \\
\hline $100^{*}$ & $\begin{array}{l}\ln \left(\mathrm{DML}_{\mathrm{TP}}\right)=4.91+1.30 *(\ln \mathrm{Q}-5.41)+0.123 *(\ln \mathrm{Q}-5.41)^{2}-0.084 *(\mathrm{~T}-2005.92) \\
\quad-0.014 * \sin \mathrm{SS}-0.044 * \cos \mathrm{SS}\end{array}$ & 0.101 & 0.318 & 97.1 \\
\hline 42 & $\ln \left(\mathrm{DML}_{\mathrm{Sed}}\right)=10.2+1.99 *(\operatorname{lnQ}-3.39)-0.237 *(\ln \mathrm{Q}-3.39)^{2}-0.139 *(\mathrm{~T}-2006.09)$ & 0.946 & 0.973 & 91.2 \\
\hline 59 & $\ln \left(\mathrm{DML}_{\mathrm{Sed}}\right)=11.2+1.9 *(\operatorname{lnQ}-3.54)-0.074 *(\ln \mathrm{Q}-3.54)^{2}$ & 1.25 & 1.117 & 87.5 \\
\hline \multicolumn{5}{|c|}{ Beaty Creek near Jay, Okla. (07191222) } \\
\hline $146^{*}$ & $\begin{array}{l}\ln \left(\mathrm{DML}_{\mathrm{TN}}\right)=5.51+1.14 *(\operatorname{lnQ}-2.80)-0.001 *(\operatorname{lnQ}-2.80)^{2}+0.014 *(\mathrm{~T}-2005.99) \\
\quad+0.013 *(\mathrm{~T}-2005.99)^{2}+0.124 * \sin \mathrm{SS}-0.124 * \cos \mathrm{SS}\end{array}$ & 0.076 & 0.276 & 98.9 \\
\hline $144 *$ & $\begin{array}{l}\ln \left(\mathrm{DML}_{\mathrm{TP}}\right)=1.31+1.30 *(\ln \mathrm{Q}-2.80)+0.059 *(\ln \mathrm{Q}-2.80)^{2}+0.018 *(\mathrm{~T}-2005.99) \\
\quad-0.178 * \sin \mathrm{SS}-0.075 * \cos \mathrm{SS}\end{array}$ & 0.149 & 0.386 & 98.4 \\
\hline 55 & $\ln \left(\mathrm{DML}_{\mathrm{Sed}}\right)=9.19+1.94 *(\ln \mathrm{Q}-3.26)+0.206 *(\ln \mathrm{Q}-3.26)^{2}-0.205 *(\mathrm{~T}-2006.29)$ & 1.00 & 1.000 & 89.6 \\
\hline
\end{tabular}


Table 4. Estimated mean annual total nitrogen, total phosphorus, and suspended sediment loads and yields using regression equations developed from concentrations in water-quality samples and streamflow, time, and seasonality, for water-quality monitoring stations in the Eucha-Spavinaw basin, Arkansas and Oklahoma, for the period 2002-10.

$\left[\mathrm{mi}^{2}\right.$, square mile; $1 \mathrm{~b} / \mathrm{yr}$, pound per year; $1 \mathrm{~b} / \mathrm{yr} / \mathrm{mi}^{2}$, pound per year per square mile; $\mathrm{N}$, nitrogen; Differences between total load and the sum of the base-flow load plus runoff loads are caused by rounding.]

\begin{tabular}{|c|c|c|c|c|c|c|c|c|}
\hline \multirow[b]{3}{*}{ Station name } & \multicolumn{8}{|c|}{ Total nitrogen } \\
\hline & \multicolumn{8}{|c|}{ Mean annual loads and yields } \\
\hline & $\begin{array}{c}\text { Mean } \\
\text { daily load } \\
\text { (lb/d as N) }\end{array}$ & $\begin{array}{l}\text { Total load }^{1} \\
\text { (Ib/yr as N) }\end{array}$ & $\begin{array}{c}\text { Total yield }^{1} \\
\text { (llb/yr/mi' as } \mathrm{N} \text { ) }\end{array}$ & $\begin{array}{l}\text { Base-flow } \\
\text { load }^{1} \\
\text { (Ib/yr as } N \text { ) }\end{array}$ & $\begin{array}{c}\text { Base-flow } \\
\text { yield } \\
\text { (lb/yr/mi' as } N)\end{array}$ & $\begin{array}{c}\text { Runoff load }{ }^{2} \\
\text { (Ib/yr as N) }\end{array}$ & $\begin{array}{c}\text { Runoff yield² } \\
\text { (Ib/yr/mi as N) }\end{array}$ & $\begin{array}{c}\text { Load } \\
\text { delivered } \\
\text { during } \\
\text { runoff } \\
\text { (percent) }\end{array}$ \\
\hline $\begin{array}{l}\text { Spavinaw Creek near } \\
\text { Maysville, Ark. } \\
(07191160)\end{array}$ & 1,660 & 607,000 & 6,880 & 204,000 & 2,320 & 402,000 & 4,560 & 66 \\
\hline $\begin{array}{l}\text { Spavinaw Creek near } \\
\text { Cherokee City, Ark. } \\
(07191179)\end{array}$ & 2,190 & 800,000 & 7,690 & 272,000 & 2,620 & 528,000 & 5,080 & 66 \\
\hline $\begin{array}{l}\text { Spavinaw Creek near } \\
\text { Sycamore, Okla. } \\
(07191220)\end{array}$ & 2,800 & $1,020,000$ & 7,680 & 310,000 & 2,330 & 712,000 & 5,340 & 70 \\
\hline $\begin{array}{l}\text { Spavinaw Creek near } \\
\text { Colcord, Okla. } \\
(071912213)\end{array}$ & 3,520 & $1,290,000$ & 7,890 & 375,000 & 2,300 & 911,000 & 5,590 & 71 \\
\hline $\begin{array}{c}\text { Beaty Creek near Jay, } \\
\text { Okla. }(07191222)\end{array}$ & 969 & 354,000 & 5,980 & 46,800 & 790 & 307,000 & 5,290 & 87 \\
\hline
\end{tabular}

\section{Total phosphorus}

Mean annual loads and yields

\begin{tabular}{|c|c|c|c|c|c|c|c|c|}
\hline Station name & $\begin{array}{c}\text { Mean } \\
\text { daily load }^{1} \\
(\mathrm{Ib} / \mathrm{d} \text { as } \mathrm{P})\end{array}$ & $\begin{array}{l}\text { Total load } \\
\text { (lb/yr as } \mathrm{P})\end{array}$ & $\begin{array}{c}\text { Total yield }{ }^{1} \\
\left(\mathrm{lb} / \mathrm{yr} / \mathrm{mi}^{2} \text { as } \mathrm{P}\right)\end{array}$ & $\begin{array}{c}\text { Base-flow } \\
\text { load }^{1} \\
\text { (Ib/yr as P) }\end{array}$ & $\begin{array}{c}\text { Base-flow } \\
\text { yield } \\
\text { (lb/yr/mi as } \mathrm{P})\end{array}$ & $\begin{array}{l}\text { Runoff load } \\
\text { (Ib/yr as P) }\end{array}$ & $\begin{array}{c}\text { Runoff yield }{ }^{2} \\
\left(\mathrm{lb} / \mathrm{yr} / \mathrm{mi}^{2} \text { as } \mathrm{P}\right)\end{array}$ & $\begin{array}{c}\text { delivered } \\
\text { during } \\
\text { runoff } \\
\text { (percent) }\end{array}$ \\
\hline $\begin{array}{l}\text { Spavinaw Creek near } \\
\text { Sycamore, Okla. } \\
(07191220)\end{array}$ & 115 & 41,900 & 315 & 7,180 & 54 & 34,700 & 261 & 83 \\
\hline $\begin{array}{c}\text { Beaty Creek near Jay, } \\
\text { Okla. }(07191222)\end{array}$ & 91 & 33,000 & 558 & 962 & 16 & 32,100 & 542 & 97 \\
\hline
\end{tabular}


Table 4. Estimated mean annual total nitrogen, total phosphorus, and suspended sediment loads and yields using regression equations developed from concentrations in water-quality samples and streamflow, time, and seasonality, for water-quality monitoring stations in the Eucha-Spavinaw basin, Arkansas and Oklahoma, for the period 2002-10.-Continued

$\left[\mathrm{mi}^{2}\right.$, square mile; $\mathrm{lb} / \mathrm{yr}$, pound per year; $\mathrm{lb} / \mathrm{yr} / \mathrm{mi}^{2}$, pound per year per square mile; $\mathrm{N}$, nitrogen; Differences between total load and the sum of the base-flow load plus runoff loads are caused by rounding.]

\begin{tabular}{|c|c|c|c|c|c|c|c|c|}
\hline \multirow[b]{3}{*}{ Station name } & \multicolumn{8}{|c|}{ Suspended sediment } \\
\hline & \multicolumn{8}{|c|}{ Mean annual loads and yields } \\
\hline & $\begin{array}{l}\text { Mean } \\
\text { daily load' } \\
(\mathrm{Ib} / \mathrm{d})\end{array}$ & $\begin{array}{l}\text { Total load } \\
\text { (lb/yr) }\end{array}$ & $\begin{array}{l}\text { Total yield }{ }^{1} \\
\text { (lb/yr/mi²) }\end{array}$ & $\begin{array}{c}\text { Base-flow } \\
\text { load' }^{1} \\
\text { (lb/yr as } N \text { ) }\end{array}$ & $\begin{array}{c}\text { Base-flow } \\
\text { yield } \\
\left(\mathrm{lb} / \mathrm{yr} / \mathrm{mi}^{2}\right)\end{array}$ & $\begin{array}{c}\text { Runoff load } \\
\text { (lb/yr) }\end{array}$ & $\begin{array}{c}\text { Runoff yield }{ }^{2} \\
\text { (lb/yr/mi²) }\end{array}$ & $\begin{array}{c}\text { Load } \\
\text { delivered } \\
\text { during } \\
\text { runoff } \\
\text { (percent) }\end{array}$ \\
\hline $\begin{array}{c}\text { Spavinaw Creek near } \\
\text { Maysville, Ark. } \\
(07191160)\end{array}$ & 62,300 & $22,700,000$ & 258,000 & 440,000 & 4,990 & $22,300,000$ & 253,000 & 98 \\
\hline $\begin{array}{c}\text { Spavinaw Creek near } \\
\text { Cherokee City, Ark. } \\
(07191179)\end{array}$ & 126,000 & $46,000,000$ & 442,000 & 684,000 & 6,580 & $45,300,000$ & 436,000 & 99 \\
\hline $\begin{array}{c}\text { Spavinaw Creek near } \\
\text { Sycamore, Okla. } \\
(07191220)\end{array}$ & 112,000 & $41,000,000$ & 309,000 & 718,000 & 5,400 & $40,300,000$ & 303,000 & 98 \\
\hline $\begin{array}{c}\text { Spavinaw Creek near } \\
\text { Colcord, Okla. } \\
(071912213)\end{array}$ & 139,000 & $50,600,000$ & 310,000 & $1,790,000$ & 11,000 & $48,800,000$ & 300,000 & 96 \\
\hline $\begin{array}{c}\text { Beaty Creek near Jay, } \\
\text { Okla. }(07191222)\end{array}$ & 178,000 & $65,000,000$ & $1,100,000$ & 148,000 & 2,500 & $64,900,000$ & $1,100,000$ & 100 \\
\hline
\end{tabular}

${ }^{1}$ Means of the base-flow loads were calculated from base-flow days data only.

${ }^{2}$ Means of the runoff loads were calculated from runoff days data only. 


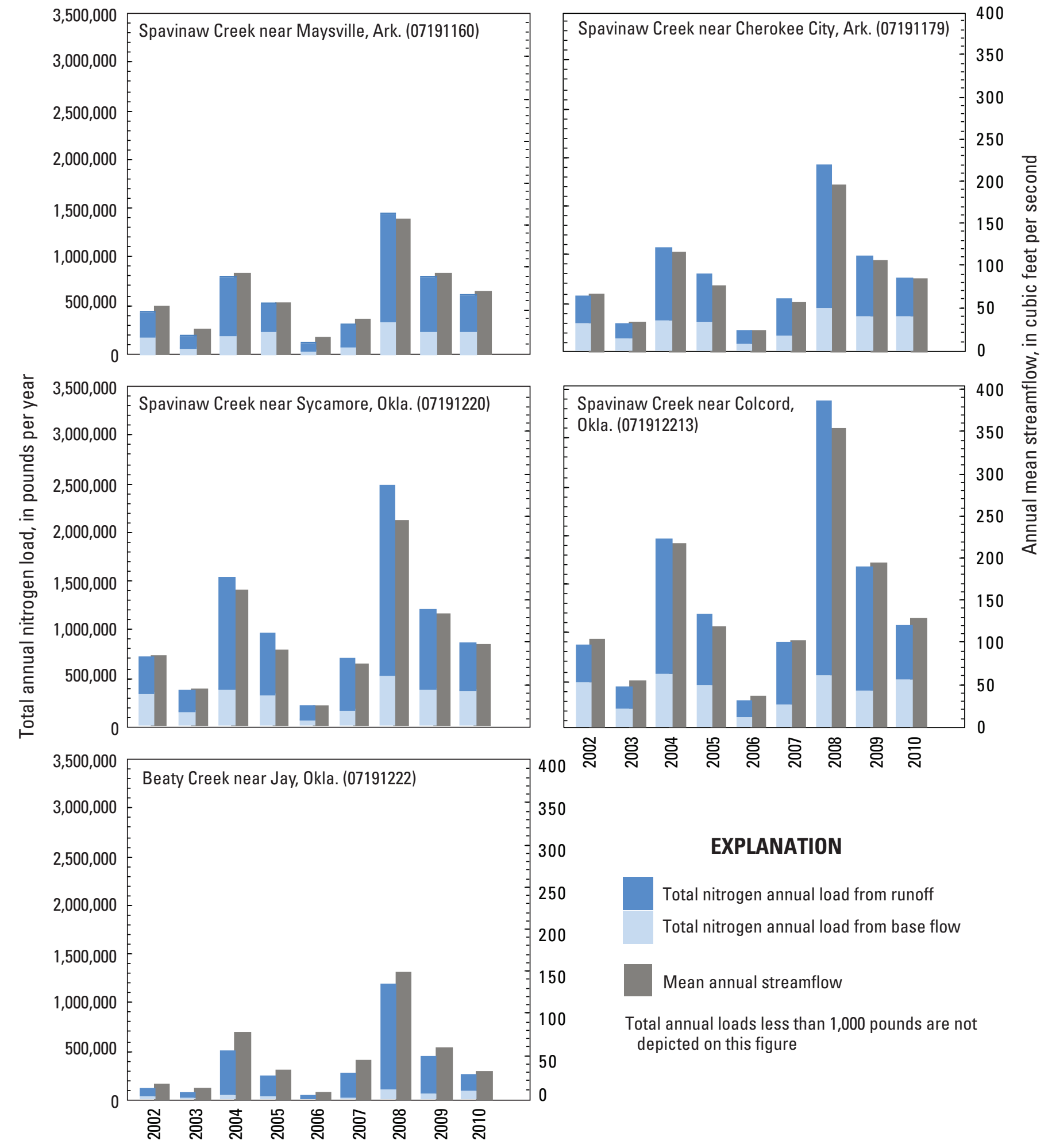

Figure 6. Estimates of base-flow and runoff components of annual total nitrogen load and mean annual streamflow at water-quality monitoring stations in the Eucha-Spavinaw basin, Arkansas and Oklahoma, 2002-10. 


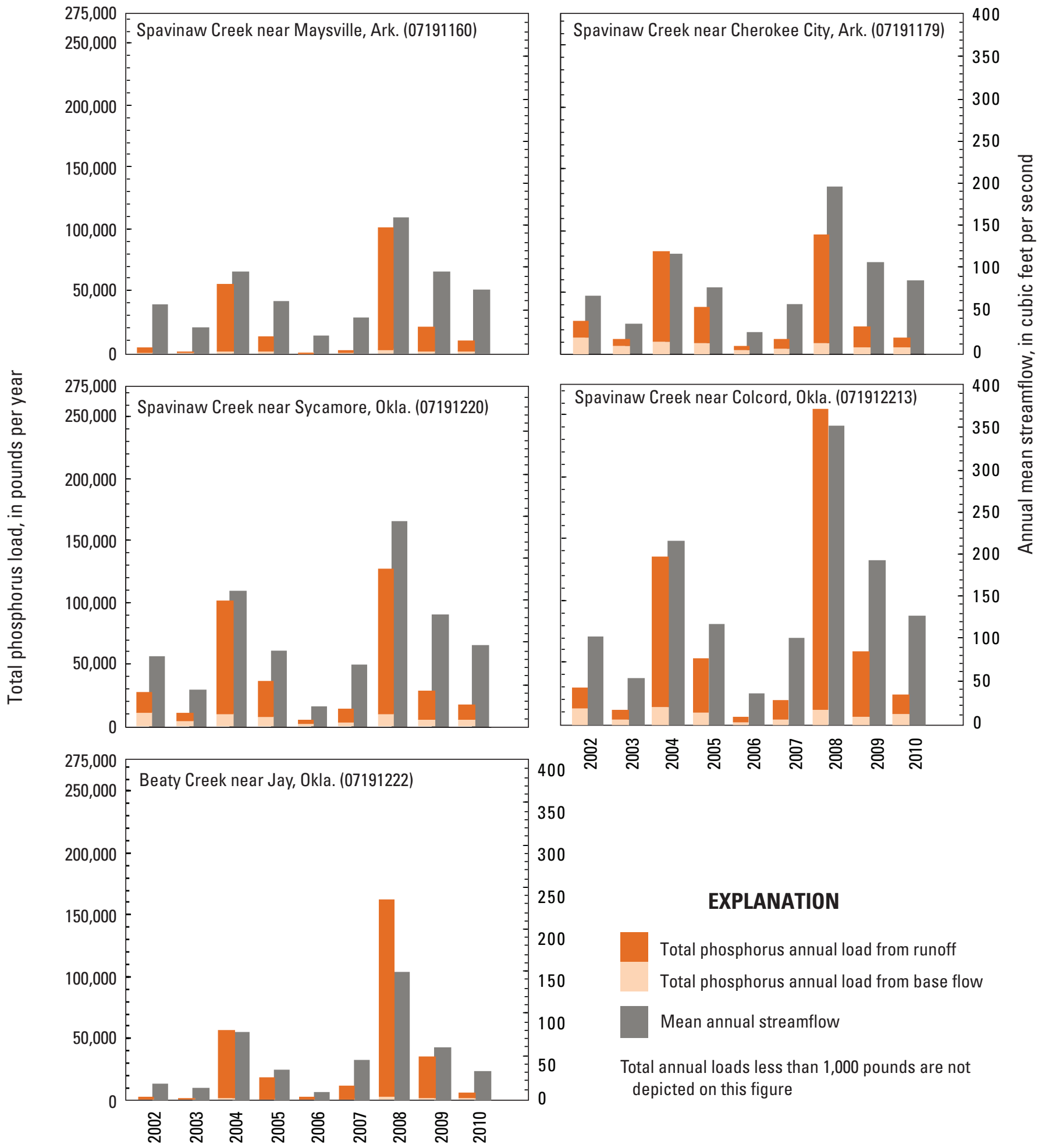

Figure 7. Estimates of base-flow and runoff components of annual total phosphorus load and mean annual streamflow, at waterquality monitoring stations in the Eucha-Spavinaw basin, Arkansas and Oklahoma, 2002-10. 
The runoff component of the mean annual total phosphorus load for the Spavinaw Creek stations ranged from 78 to 92 percent and generally increased in a downstream direction from the Cherokee City station to the Colcord station (table 4). About 97 percent of the annual phosphorus load at the Beaty Creek station was derived from runoff (table 4). The runoff components of phosphorus were only about 1 percent less in 2002-10 than those in 2002-09 (table 4, Esralew and Tortorelli, 2010).

Mean annual total phosphorus yields ranged from 284 to $558 \mathrm{lbs} / \mathrm{yr} / \mathrm{mi}^{2}$ (table 4). Mean annual total phosphorus yields in Spavinaw Creek generally increased in a downstream direction with the exception of the Cherokee City station, which is the first station downstream from the outfall of the Decatur wastewater-treatment plant, having greater total and base-flow yields than at the downstream Sycamore station. The mean total and runoff phosphorus yields for Beaty Creek, however, were greater than any of the Spavinaw Creek stations, perhaps because of less forested riparian areas in the Beaty Creek basin (fig. 2).

Phosphorus loading to streams is increased more in runoff conditions than nitrogen loading in this basin (Esralew and Tortorelli, 2010). Association of phosphorus with sediment may contribute to the greater transport of phosphorus during runoff conditions. A substantial source of nitrogen loading may be from nitrate delivered to the stream in groundwater seepage (Esralew and Tortorelli, 2010), explaining the greater proportion of base-flow transport for nitrogen. The greater total and runoff phosphorus yields in Beaty Creek compared to Spavinaw Creek may be caused by a greater contribution of nonpoint sources of phosphorus in Beaty Creek or by a greater percentage of streamflow from runoff, the main component of phosphorus transport, in Beaty Creek. Variability of baseflow phosphorus loads and yields among Spavinaw Creek stations, especially at the Cherokee City station, may have been caused by inflow of wastewater effluent from the Decatur wastewater-treatment plant between the Maysville station and Cherokee City station, with decreasing yields downstream from the Cherokee City station being caused by addition by groundwater seepage (Esralew and Tortorelli, 2010).

\section{Sediment Loads and Yields}

Mean annual total sediment loads from 2002-10 estimated from $\mathrm{DM}_{\mathrm{L}}$ regressions ranged from $22,700,000$ to $65,000,000 \mathrm{lbs} / \mathrm{yr}$. Estimated mean annual total sediment load and the runoff component of total load generally were similar at the three downstream Spavinaw Creek stations (table 4) and were smallest at the Maysville station. The Beaty Creek station had the largest mean annual sediment load $(65,000,000 \mathrm{lbs} / \mathrm{yr})$ and the largest annual sediment load (360,000,000 lbs/yr) in 2008 (fig. 8). For the Spavinaw Creek stations, the Colcord City station had the greatest mean annual sediment load $(50,600,000 \mathrm{lbs} / \mathrm{yr})$, with the greatest annual load of sediment also being at the Colcord station in 2008 (275,000,000 lbs/yr, fig. 8). The years 2004 and 2008, which had the greatest streamflow (table 2), also had the greatest sediment load (fig. 8). For example, 77 percent of the sediment load for the period 2002-10 at the Colcord station and 91 percent of the sediment load at the Beaty Creek station occurred during 2004 and 2008.

The greater mean annual total and runoff sediment load estimates obtained for the Cherokee City station than at the Sycamore station indicate that sediment deposition occurred between these stations, which may have been facilitated by decreases or irregular changes in flow downstream causing changes in sediment transport capacity between these stations. Losses of streamflow to groundwater were observed, with streamflow being less at the Sycamore station than at the Cherokee City station during 25 percent of the study period, 20 percent of which were runoff days. Base-flow sediment loads were relatively small (less than 5 percent of the total load) at the five stations. The runoff component of the mean annual sediment load for Beaty Creek was 100 percent, with the runoff component of the mean annual sediment load at the Spavinaw Creek stations ranging from 96 to 99 percent (table 4). Runoff and total loads increased with larger drainage areas for Spavinaw Creek but were greater at the Beaty Creek station than any of the Spavinaw Creek stations.

Mean annual total sediment yields ranged from 258,000 to $1,100,000 \mathrm{lbs} / \mathrm{yr} / \mathrm{mi}^{2}$. Mean annual total and runoff sediment yields for the Spavinaw Creek stations were greatest at the Cherokee City station, similar between the Sycamore and Colcord stations, and smallest at the Maysville station (table 4). Mean annual total and runoff sediment yields at the Beaty Creek station were about 2 to 4 times greater than yields at the Spavinaw Creek stations (table 4). The greater sediment yield at the Cherokee City station than at the Maysville station and the decreasing sediment yield between the Cherokee City station and the downstream station at Sycamore indicate that substantial sediment inputs, derived from land or streambank erosion or resuspension of streambed sediments, occur between the Maysville and the Cherokee City stations. Decrease in sediment yield between the Cherokee City and Sycamore stations may be caused by sediment deposition between those stations. Increases in sediment yield with increasing drainage basin size, as between the Maysville and Cherokee City stations, may be caused by dominance of bank erosion or changes in land use, whereas uniform or decreasing sediment yield with drainage area, as was observed between the Sycamore and Colcord stations, may be caused by dominance of hillslope erosion (Birkinshaw and Bathurst, 2006). Similar to phosphorus, the greater total and runoff sediment yields in Beaty Creek compared to Spavinaw Creek may be caused by a greater contribution of nonpoint sediment sources in the Beaty Creek basin, which has less forested riparian areas, or by a greater percentage of streamflow from runoff, the main source of sediment transport, for Beaty Creek. 


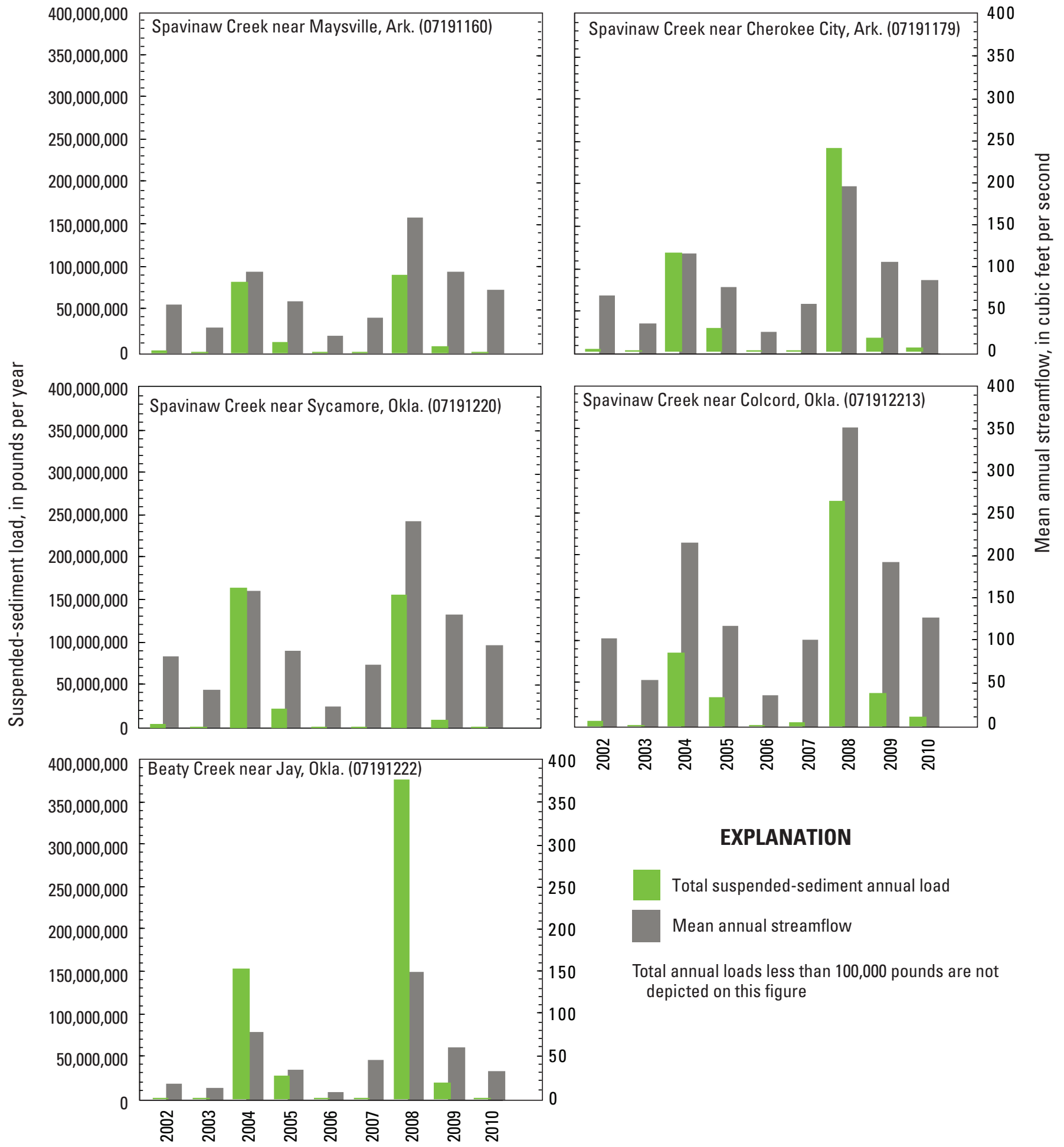

Figure 8. Estimates of base-flow and runoff components of suspended-sediment annual load and mean annual streamflow, at waterquality monitoring stations in the Eucha-Spavinaw basin, Arkansas and Oklahoma, 2002-10. 


\section{Estimated Mean Annual Nitrogen, Phosphorus, and Sediment Loads into Lake Eucha}

Much of the mean annual nitrogen and phosphorus loads entering Lake Eucha can be estimated by adding the loads at the Beaty Creek station and the Colcord station on Spavinaw Creek. Nitrogen and phosphorus loads at these stations do not represent the entire loads of those constituents into Lake Eucha, but the drainage area upstream from these stations accounts for about 62 percent of the Lake Eucha drainage basin. Spavinaw Creek and Beaty Creek contributed a mean annual total nitrogen load of about 1,640,000 lbs/yr, with 74 percent of the annual total nitrogen load being transported to Lake Eucha during runoff conditions (table 5). Spavinaw Creek contributed a majority of the mean annual nitrogen load of the two creeks (78 percent).

Spavinaw Creek near Colcord and Beaty Creek contributed a mean annual total phosphorus load of 100,000 $\mathrm{lbs} / \mathrm{yr}, 90$ percent of which was transported to Lake Eucha during runoff conditions (table 5). The majority of the phosphorus (67 percent) was derived from the Spavinaw Creek basin. Spavinaw Creek and Beaty Creek contributed a combined mean annual total sediment load of about $116,000,000 \mathrm{lbs} / \mathrm{yr}$ with 98 percent of the annual total phosphorus load being transported to Lake Eucha during runoff conditions (table 5). About 56 percent of the estimated total sediment load was from the drainage area of the Beaty Creek station.

Mean annual total nitrogen loads from 2002-10 were 2.5 percent less and mean annual total phosphorus loads were 7.8 percent less than those reported for 2002-09 (table 5, Esralew and Tortorelli, 2010). These decreases indicated that nitrogen and phosphorus loads in 2010 were below average compared to loads from 2002-09. However, percent contributions of nitrogen and phosphorus load from both creeks and during base-flow and runoff conditions were within 1 percent of those reported in Esralew and Tortorelli (2010).

\section{Estimation of Instantaneous Concentrations from Water-Quality Samples, Streamflow, and Real-Time Continuous Water-Quality Data for 2005-10}

Instantaneous concentration regression equations used for load computations are listed in table 6. Regressions using base-10 and natural logarithm transformations are presented for comparison with previously reported $\mathrm{DM}_{\mathrm{L}}$ regressions of Esralew and Tortorelli (2010), which used natural logarithms, and previously reported INST $_{C}$ regression equations developed by Christensen and others (2008), which used base-10 logarithmic transformations. Both equations produce equivalent estimates and have the same RMSE, $\mathrm{R}^{2}$, and bias correction factors.
Nitrogen

Turbidity, streamflow, and seasonality were used in $\mathrm{INST}_{\mathrm{C}}$ regressions to estimate nitrogen concentration at the Colcord station (table 6). Turbidity was positively associated with nitrogen, which may be related to particulate organic nitrogen that coincides with transport of sediment. The streamflow terms were quadratic with a negative square term $\left(\mathrm{Q}-\mathrm{Q}^{2}\right)$, indicating a nonlinear increase of nitrogen with streamflow, and that at higher streamflows, such as near or after the peak of a storm event, dilution may cause the rate of increase in concentrations, with respect to streamflow, to decline relative to the start of a storm event. Nitrogen concentrations varied with season, generally being greater in winter and spring than in summer and fall (Esralew and Tortorelli, 2010).

Temperature, specific conductance, turbidity, and streamflow were used in the $\mathrm{INST}_{\mathrm{C}}$ regression to estimate nitrogen concentration at the Beaty Creek station (table 6). Those variables, except temperature, were positively correlated with nitrogen concentration. Positive turbidity and streamflow terms indicate sources of nitrogen from runoff. A positive correlation between nitrogen concentration and specific conductance, which tends to decrease with increasing streamflow, may serve a similar function to the quadratic streamflow term used in the regression equation for the Colcord station. The negative correlation with temperature likely reflects elevated nitrogen concentrations observed in winter and spring compared to summer and fall (Esralew and Tortorelli, 2010), which may be because of greater seasonal application and runoff of animal wastes and other fertilizers.

The addition of seasonality and temperature as variables, use of quadratic terms, and availability of additional data contribute to the differences between the current and previous $\mathrm{INST}_{\mathrm{C}}$ regression equations (Christensen and others, 2008). The previous INST $_{C}$ regression equations developed by Christensen and others (2008) to estimate nitrogen at both stations differ from those developed for this report. For example, the nitrogen $\mathrm{INST}_{\mathrm{C}}$ regression for the Colcord station from Christensen and others (2008) included specific conductance and turbidity, which were negatively correlated to nitrogen concentration and the regression for the Beaty Creek station included streamflow. Christensen and others (2008) reported substantial seasonality in regression error residuals, which may have been reduced after use of seasonal terms in the new $\mathrm{INST}_{\mathrm{C}}$ regressions. The new $\mathrm{INST}_{\mathrm{C}}$ regression developed for the Colcord station for this report had better fit to the field data compared to the nitrogen regression in Christensen and others (2008), as indicated by an increase in the $\mathrm{R}^{2}$ from 0.708 in that report to 0.777 in this report. The new $\mathrm{INST}_{\mathrm{C}}$ regression developed for the Beaty Creek station for this report also had improved fit compared to the nitrogen regression in Christensen and others (2008) as indicated by an increase in the $\mathrm{R}^{2}$ from 0.602 in the that report to 0.647 in this report. 


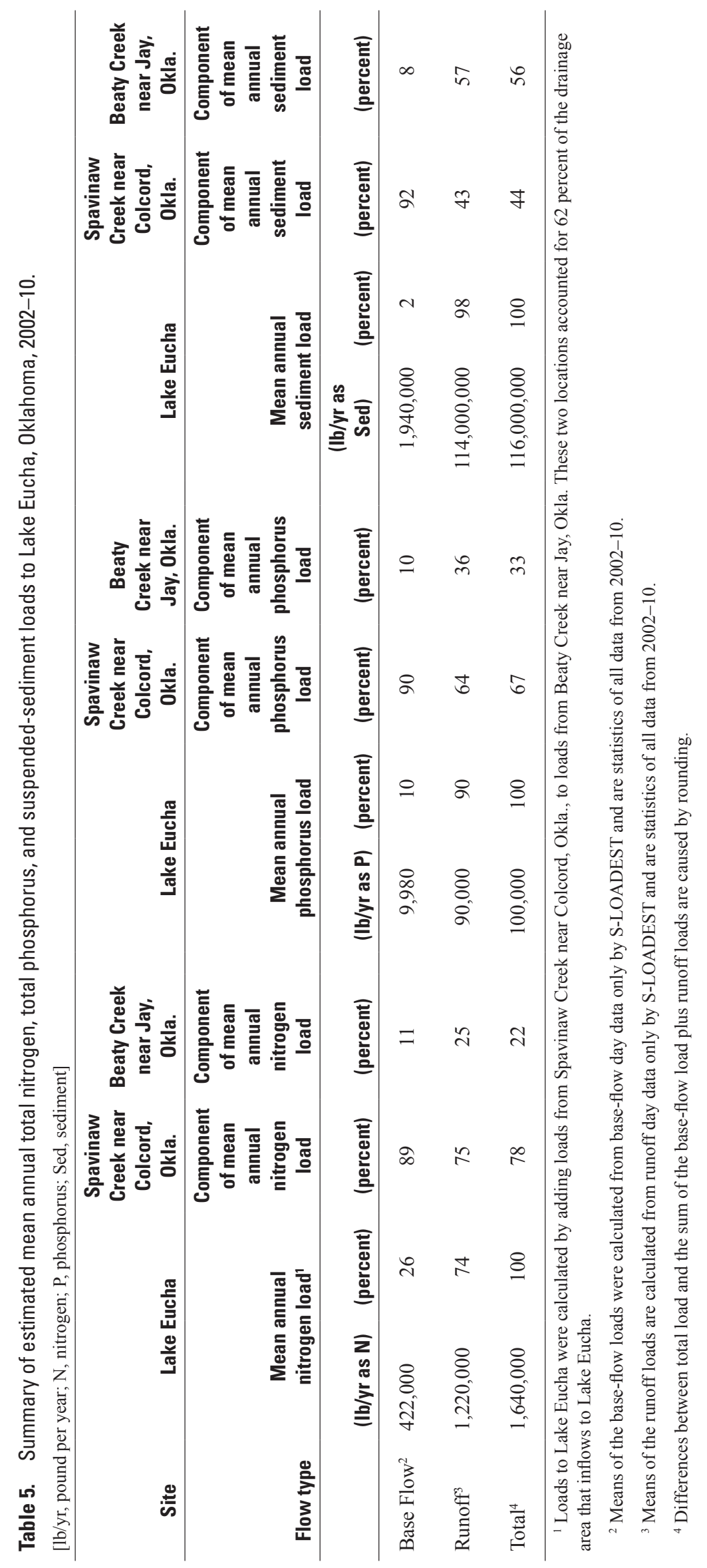




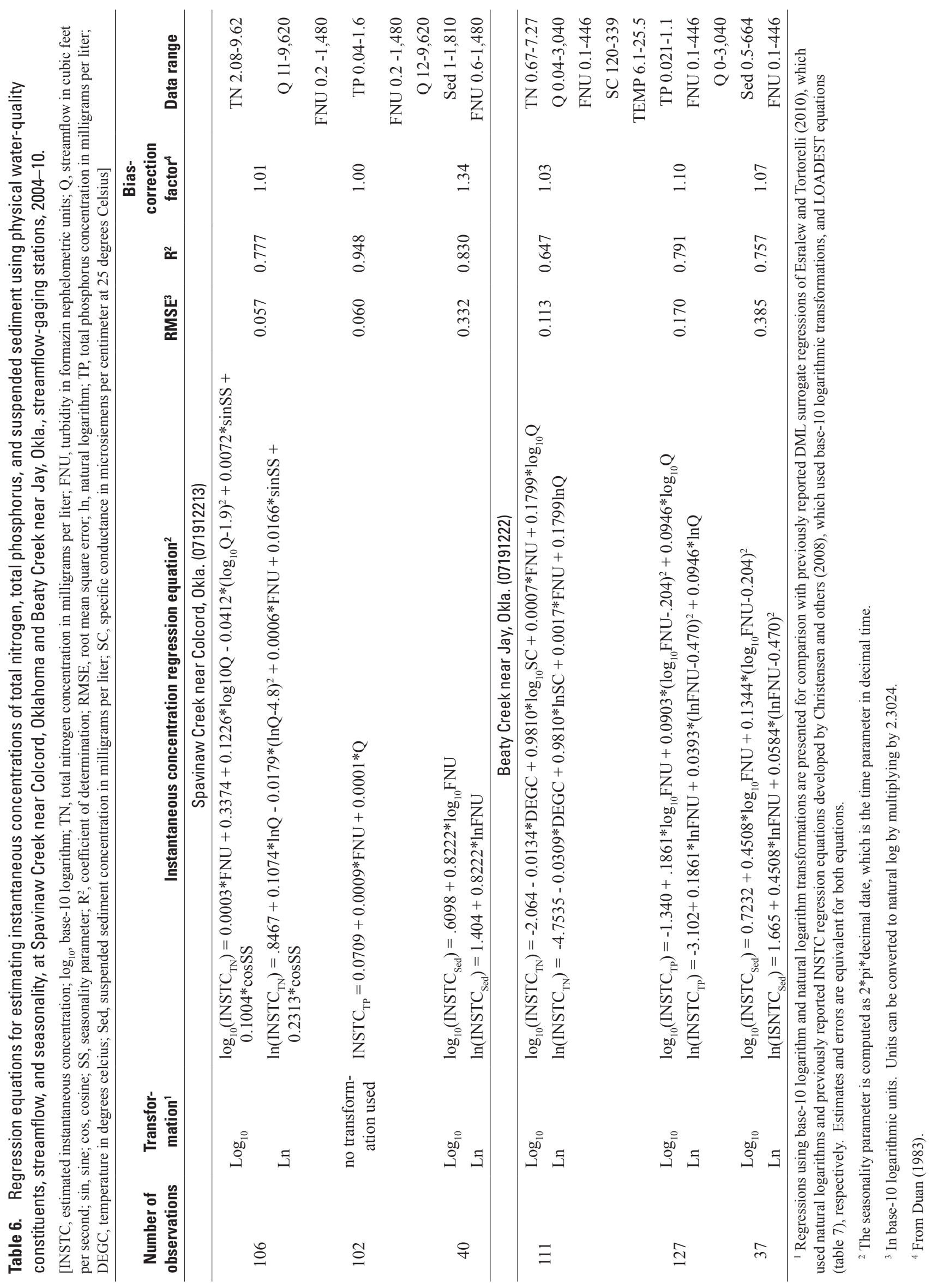




\section{Phosphorus}

Turbidity and streamflow were used as independent variables for the $\mathrm{INST}_{\mathrm{C}}$ regression equation developed to estimate phosphorus concentrations at the Colcord station (table 6). Turbidity and streamflow were positively correlated with phosphorus, indicating increases in sediment-sorbed phosphorus during runoff. Error residuals from the INST $_{C}$ regression had a slight negative correlation with time, when data from 2004 through 2010 were used, indicating a downward trend in phosphorus concentration. Plots of error residuals (fig. 9) also indicated decreases in estimated phosphorus concentrations from October 2004 through October 2007. An INST $_{C}$ regression using data from October 2007 through September 2010 was used to eliminate temporal trends in the error residuals. No temporal trends were detected with residuals when this later period was used. However, the regression equation developed using these later dates had a substantially poorer fit to the data, as indicated by an $\mathrm{R}^{2}$ of 0.591 compared to 0.948 using data from November 2004 through September 2010. This decrease in fit probably was caused by several phosphorus samples collected from 2004 through 2007 being associated with extremely high streamflows (greater than the 2 percent streamflow exceedance probability), which had substantial leverage on the INST regression. Because the trend was slight ( $\mathrm{p}$-value and tau were 0.02 and -0.16), this difference may indicate a slight tendency of the $\mathrm{INST}_{\mathrm{C}}$ regressions to overestimate phosphorus concentrations. Additional runoff samples and relatively frequent updates of this regression using new data could improve regression estimates.

Turbidity and streamflow also were the variables selected to estimate phosphorus concentration using the $\mathrm{INST}_{\mathrm{C}}$ regression for the Beaty Creek station. Like the Colcord $\mathrm{INST}_{\mathrm{C}}$ regression, positive turbidity and streamflow terms indicate increases of phosphorus concentration with runoff. The relation of phosphorus concentration with turbidity and streamflow is because of the association of phosphorus with sediment. When streamflow increases because of runoff, turbidity and phosphorus increase as runoff transports increasing concentrations of sediment-sorbed phosphorus. A quadratic turbidity term $\left(\mathrm{FNU}+\mathrm{FNU}^{2}\right)$ fits the phosphorus concentration data better than a linear turbidity term. This relation may indicate that at higher turbidity values, there may have been a decrease in the relation between turbidity with sediment at larger suspended-sediment concentrations (Gloria Ferrell, U.S. Geological Survey, written commun., 2011).

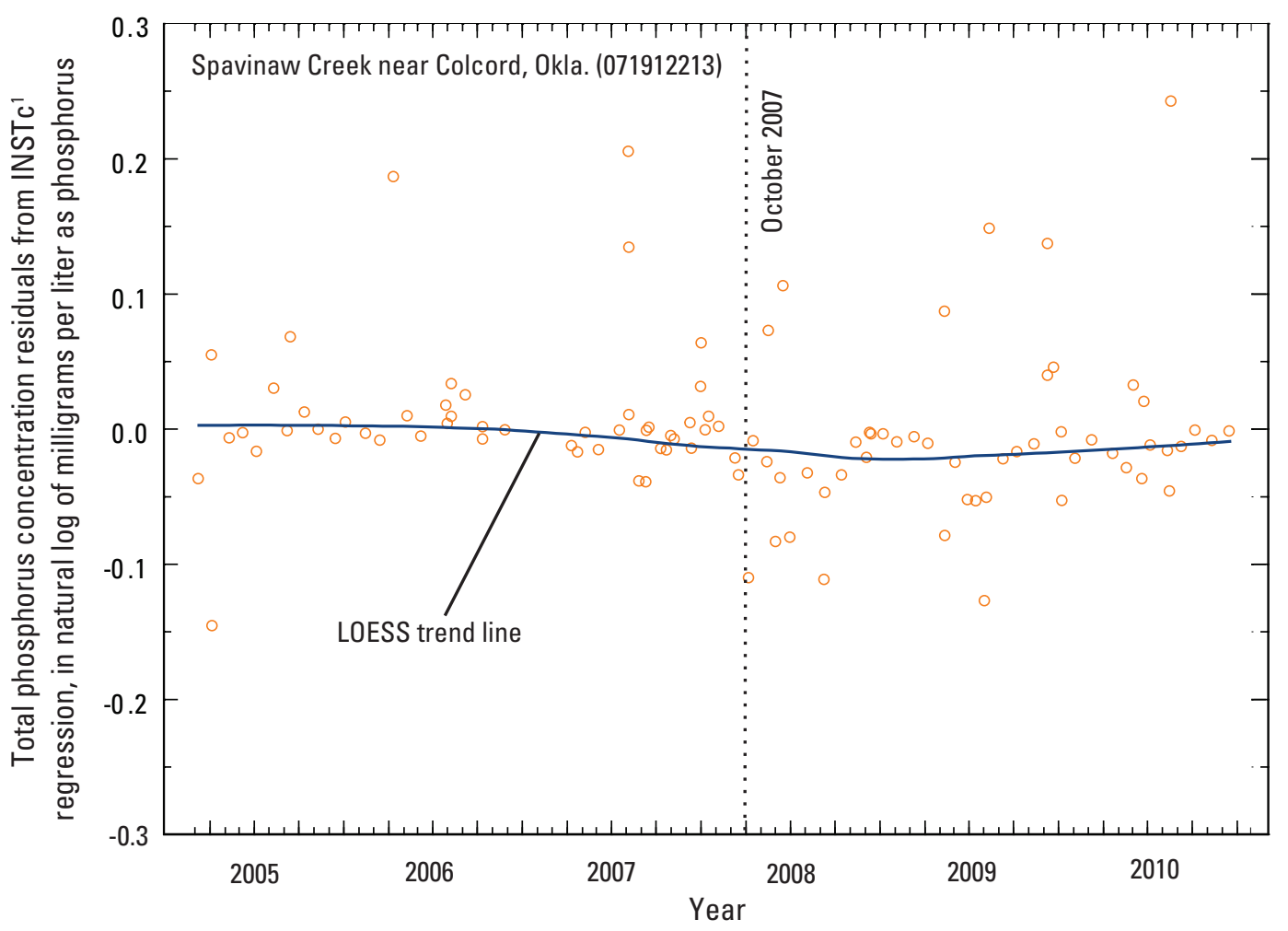

'INSTc regression, regression used to estimate constituent concentrations where physical water-quality constituents, streamflow, and seasonality are independent variables

Figure 9. Trends in error residuals of regression-estimated total phosphorus concentrations at Spavinaw Creek near Colcord, Oklahoma, streamflow-gaging station, 2004-10. 
Differences in the fit and types of variables from those used in previous $\mathrm{INST}_{\mathrm{C}}$ regression equations (Christensen and others, 2008) may have been the result of new concentration data from 2007 through 2010 or changes in relations between phosphorus, turbidity, and streamflow. The previous INST $_{C}$ regression developed to estimate phosphorus at the Colcord station was nearly identical to the regression developed in this report. However, the INST $_{C}$ regression developed to estimate phosphorus concentration at the Beaty Creek station in Christensen and others (2008) differed substantially from the new INST $_{C}$ regression largely because the previous regressions did not include a quadratic turbidity term and were not log-transformed. Graphs of phosphorus concentration and turbidity using data collected from 2004 to 2010 indicated a logarithmic fit. The new INST ${ }_{C}$ regression developed for the Colcord station for this report had slightly reduced fit compared to the phosphorus regression in Christensen and others (2008) as indicated by a slight decrease in $\mathrm{R}^{2}$ from 0.958 to 0.948 . The new INST ${ }_{C}$ regression developed for the Beaty Creek station for this report had reduced fit compared to the nitrogen regression in Christensen and others (2008) as indicated by a decrease in $\mathrm{R}^{2}$ from 0.978 to 0.791 (table 6).

\section{Sediment}

Turbidity was selected as the independent variable in the $\mathrm{INST}_{\mathrm{C}}$ regression developed to estimate sediment concentrations at the Colcord station (table 6). Turbidity was positively correlated with phosphorus, indicating increases in phosphorus sorbed to sediments during runoff. Turbidity also was the independent variable in the $\mathrm{INST}_{\mathrm{C}}$ regression used to estimate sediment concentration at the Beaty Creek station. A quadratic turbidity term (FNU $\left.+\mathrm{FNU}^{2}\right)$ was used to fit the sediment concentration data better than a linear turbidity term, slightly improving regression fit, indicating that at greater turbidity, sediment concentrations may increase at a faster rate than at lesser turbidity.

\section{Comparison of Regression-Based Load Estimates}

Nitrogen, phosphorus, and sediment annual loads and yields were compared for the period 2005-10 for the Colcord station and 2006-10 for the Beaty Creek station using two regression methods. Annual total loads and mean annual total loads were from: (a) $\mathrm{DM}_{\mathrm{L}}$ regressions used to estimate daily mean load based on streamflow, seasonality, and time (table 3), and (b) $\mathrm{INST}_{\mathrm{C}}$ regressions used to estimate instantaneous concentrations based on physical water-quality constituents (turbidity, specific conductance, temperature), streamflow, and seasonality (table 6). Accuracy of $\mathrm{INST}_{C}$ regressions were compared to alternate $\mathrm{INST}_{\mathrm{C}}$ regressions using streamflow and time as the only independent variables in order to determine if inclusion of water-quality constituents in concentration and load estimation regression improves fit of the regression.

Comparison of load estimates indicated that daily, annual, and mean annual loads varied substantially depending on the independent variables used to develop the regression equations. For each constituent at both stations, concentrations estimated from INST $_{\mathrm{C}}$ regressions with streamflow, seasonality, and physical water-quality parameters such as turbidity, temperature, and specific conductance, had better fit than estimates from alternate INST $_{C}$ regressions that only included streamflow and seasonality, as indicated by $\mathrm{R}^{2}$ and RMSE values (table 7). Regression-estimated loads using physical water-quality parameters are also useful because data are provided at more frequent intervals than a daily mean and can better describe variability in concentrations and loads. Because the majority of constituent load was delivered during a relatively small number of streamflow events, variability in hourly load estimation can be important in quantifying total loads. However, many instantaneous and daily load estimates for extreme high streamflow events were extrapolated beyond the range of water- quality and streamflow conditions for which the samples used to develop the regressions were collected, indicating that fit of load computations could be improved with data from additional high-flow samples.

\section{Nitrogen}

Estimates of mean annual nitrogen loads did not differ substantially between the two regression methods for either station (table 8, figs. 10-11). For both stations, the relative percent difference (RPD) between the mean annual total nitrogen and runoff-load estimates obtained by the two regression methods were within 2 percent. However, the RPD in mean annual nitrogen base-flow load was -12.1 percent for the Beaty Creek station (fig. 11). Estimated 90 percent prediction intervals were similar for annual total nitrogen loads estimated for the Colcord and Beaty Creek stations for both types of regressions (fig. 10).

The RPDs between annual total nitrogen loads estimated from the $\mathrm{DM}_{\mathrm{L}}$ and $\mathrm{INST}_{\mathrm{C}}$ regression equations ranged from -0.8 to 1.6 percent for the Colcord station and -22.5 to 12.4 for the Beaty Creek station. For the Beaty Creek station, annual total nitrogen and runoff loads estimated from the $\mathrm{DM}_{L}$ regression were less than those estimated from the INST $_{\mathrm{C}}$ regression for 2006-08 but were greater than those estimated from the $\mathrm{INST}_{\mathrm{C}}$ regression for 2009-10. 
Table 7. Alternate regression equations for estimating instantaneous concentrations of total nitrogen, total phosphorus, and suspended sediment using streamflow and seasonality parameters for Spavinaw Creek near Colcord, Oklahoma, and Beaty Creek near Jay, Okla., streamflow-gaging stations, 2004-10.

$\left[\log _{10}\right.$; base-10 logarithm; INSTC, estimated instantaneous concentration; TN, total nitrogen concentration in milligrams per liter; FNU, turbidity in formazin nephelometric units; Q, instantaneous streamflow in cubic feet per second; sin, sine; cos, cosine; SS, seasonality; R², coefficient of determination; RMSE, root mean square error; ln, natural logarithm; TP, total phosphorus concentration in milligrams per liter; DEGC, temperature in degrees Celsius; Sed, suspended sediment concentration in milligrams per liter; SC, specific conductance in microsiemens per centimeter at 25 degrees Celsius]

\begin{tabular}{|c|c|c|c|c|}
\hline $\begin{array}{c}\text { Number of } \\
\text { observations }\end{array}$ & Instantaneous concentration regression model ${ }^{1}$ & RMSE $^{2}$ & $\mathbf{R}^{2}$ & $\begin{array}{c}\text { Bias- } \\
\text { correction } \\
\text { factor }^{3}\end{array}$ \\
\hline \multicolumn{5}{|c|}{ Spavinaw Creek near Colcord, Okla. (071912213) } \\
\hline 106 & $\ln \left(\mathrm{INSTC}_{\mathrm{TN}}\right)=0.8054+0.1159 * \ln \mathrm{Q}-0.0091 *(\ln \mathrm{Q}-5.03)^{2}+0.0183 * \operatorname{sinSS}+0.2178 * \cos S \mathrm{~S}$ & 0.068 & 0.697 & 1.01 \\
\hline 102 & $\mathrm{INSTC}_{\mathrm{TP}}=0.0772+0.0002 * \mathrm{Q}$ & 0.149 & 0.669 & 1.00 \\
\hline 40 & $\ln \left(\mathrm{INSTC}_{\mathrm{Sed}}\right)=-1.65+0.848 * \ln \mathrm{Q}$ & 0.54 & 0.549 & 1.59 \\
\hline 111 & $\ln \left(\mathrm{INSTC}_{\mathrm{TN}}\right)=.4203+0.1427 * \operatorname{lnQ}-0.0761 *(\operatorname{lnQ}-3.66)^{2}+0.0761 * \operatorname{sinSS}+0.1690 * \operatorname{cosSS}$ & 0.118 & 0.628 & 1.04 \\
\hline 127 & $\ln \left(\mathrm{INSTC}_{\mathrm{TP}}\right)=-4.1145+0.368 * \ln \mathrm{Q}+0.051 *(\ln \mathrm{Q}-3.66)^{2}-0.150 * \operatorname{sinSS}-0.080 * \operatorname{cosSS}$ & 0.184 & 0.747 & 1.10 \\
\hline 37 & $\ln \left(\mathrm{INSTC}_{\mathrm{Sed}}\right)=.125+0.4348 * \ln \mathrm{Q}+0.214 *(\ln \mathrm{Q}-3.66)^{2}$ & 0.473 & 0.632 & 1.39 \\
\hline
\end{tabular}

${ }^{1}$ The seasonality parameter is computed as $2 * \mathrm{pi} *$ decimal date, which is the time parameter in decimal time.

${ }^{2}$ In base-10 logarithmic units. Units can be converted to natural log by dividing by 2.3024 .

${ }^{3}$ From Duan (1983).

Table 8. Estimated mean annual total nitrogen, total phosphorus, and suspended-sediment loads and yields by using two different regression equations for streamflow-gaging stations in the Eucha-Spavinaw basin, Arkansas and 0klahoma, 2002-10.

[NWIS, National Water Information System of the U.S. Geological Survey; DML, annual load computed from estimated concentrations from a regression using annual load estimated from a regression using streamflow, seasonality, and time (table 3); INST $_{C}$, annual load computed from estimated concentrations from a regression using physical water-quality constituents, streamflow, and seasonality (table 6); $\mathrm{mi}^{2}$, square mile; $\mathrm{lb} / \mathrm{yr}$, pound per year; lb/yr/mi ${ }^{2}$ pound per year per square mile; SEP, standard error of prediction; N, nitrogen; Differences between total load and the sum of the base-flow load plus runoff loads are caused by rounding]

Total nitrogen

\begin{tabular}{|c|c|c|c|c|c|c|c|c|}
\hline $\begin{array}{c}\text { Station name } \\
\text { (NWIS number) }\end{array}$ & $\begin{array}{l}\text { Regression } \\
\text { type }\end{array}$ & \multicolumn{7}{|c|}{ Mean annual load } \\
\hline $\begin{array}{l}\text { Spavinaw } \\
\text { Creek near }\end{array}$ & $\mathrm{DM}_{\mathrm{L}}$ & $1,440,000$ & 8,830 & 348,000 & 2,135 & $1,100,000$ & 6,750 & 76 \\
\hline $\begin{array}{l}\text { Colcord, Okla. } \\
(071912213)\end{array}$ & $\mathrm{INST}_{\mathrm{C}}$ & $1,450,000$ & 8,900 & 352,000 & 2,160 & $1,100,000$ & 6,750 & 76 \\
\hline $\begin{array}{l}\text { Beaty Creek } \\
\text { near Jay, Okla. }\end{array}$ & $\mathrm{DM}_{\mathrm{L}}$ & 448,000 & 7,570 & 55,500 & 938 & 392,000 & 6,620 & 88 \\
\hline$(07191222)$ & $\mathrm{INST}_{\mathrm{C}}$ & 448,000 & 7,570 & 49,200 & 831 & 399,000 & 6,740 & 89 \\
\hline
\end{tabular}


Table 8. Estimated mean annual total nitrogen, total phosphorus, and suspended-sediment loads and yields by using two different regression equations for streamflow-gaging stations in the Eucha-Spavinaw basin, Arkansas and Oklahoma, 2002-10.-Continued

[NWIS, National Water Information System of the U.S. Geological Survey; DML, annual load computed from estimated concentrations from a regression using annual load estimated from a regression using streamflow, seasonality, and time (table 3); INST $_{\mathrm{C}}$, annual load computed from estimated concentrations from a regression using physical water-quality constituents, streamflow, and seasonality (table 6 ); $\mathrm{mi}^{2}$, square mile; $1 \mathrm{~b} / \mathrm{yr}$, pound per year; $1 \mathrm{~b} / \mathrm{yr} / \mathrm{mi}^{2}$, pound per year per square mile; SEP, standard error of prediction; N, nitrogen; Differences between total load and the sum of the base-flow load plus runoff loads are caused by rounding]

Total phosphorus

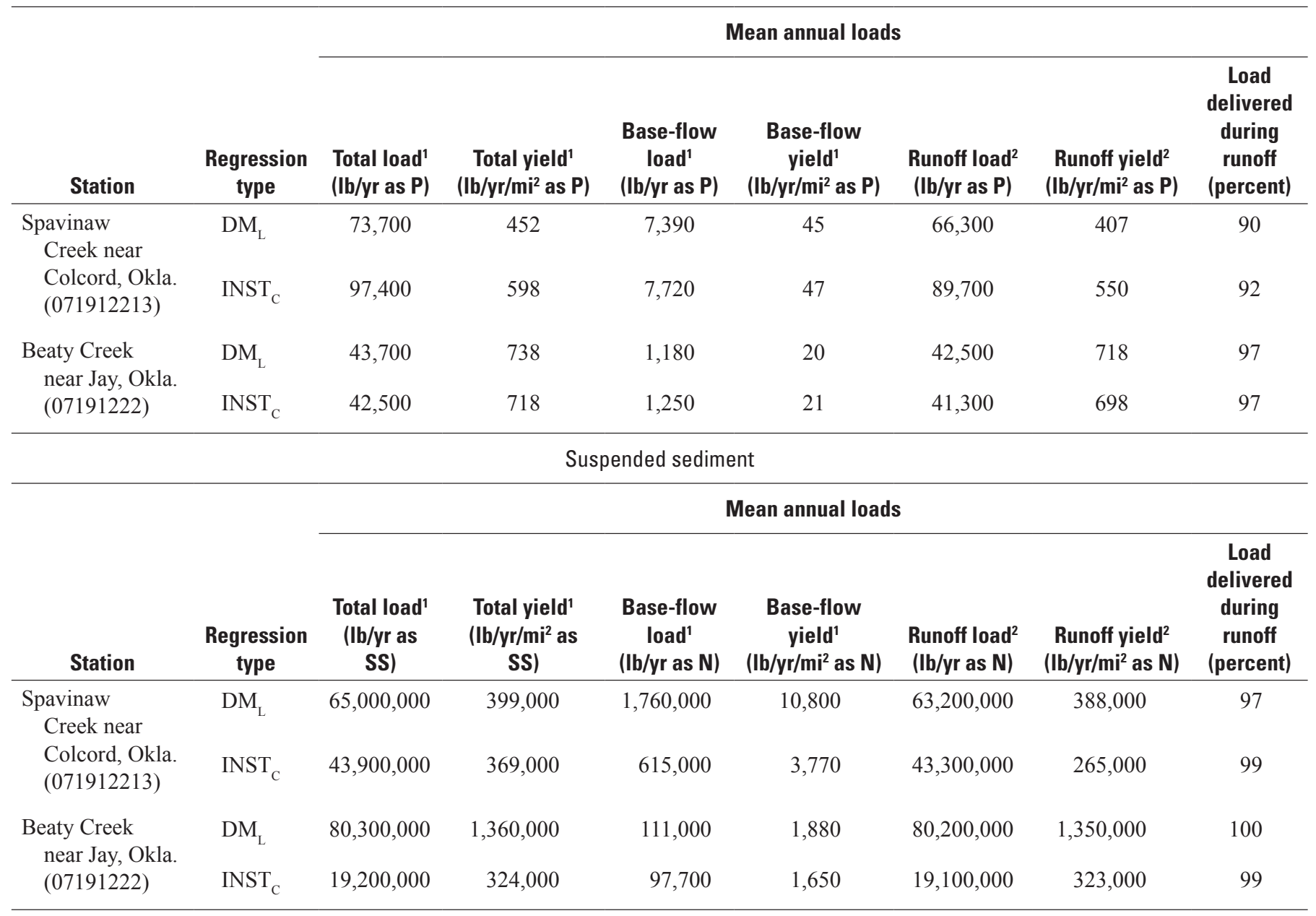

${ }^{1}$ Means of the base-flow loads are calculated from base-flow days data only.

${ }^{2}$ Means of the runoff loads are calculated from runoff days data only. 


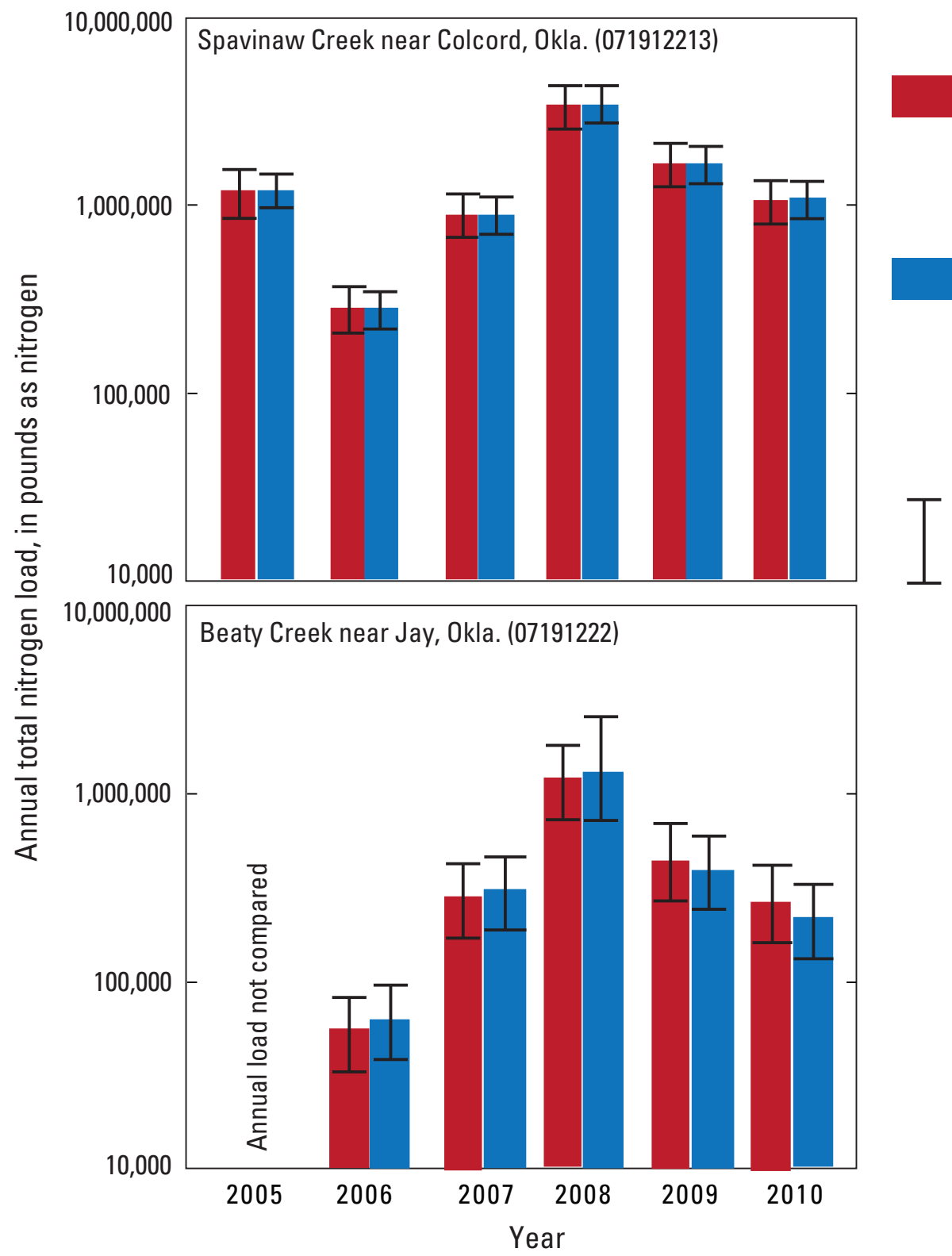

\section{EXPLANATION}

$\mathrm{DM}$ regression estimate, annual load estimated from a regression using streamflow, seasonality, and time

INSTc regression estimate, annual load computed from estimated concentrations from a regression using physical water-quality constituents, streamflow, and seasonality

Estimated upper and lower 90-percent prediction intervals

Figure 10. Annual total nitrogen load estimated using two regression methods at Spavinaw Creek near Colcord, Oklahoma, and Beaty Creek near Jay, Okla., streamflow-gaging stations, 2005-10. 

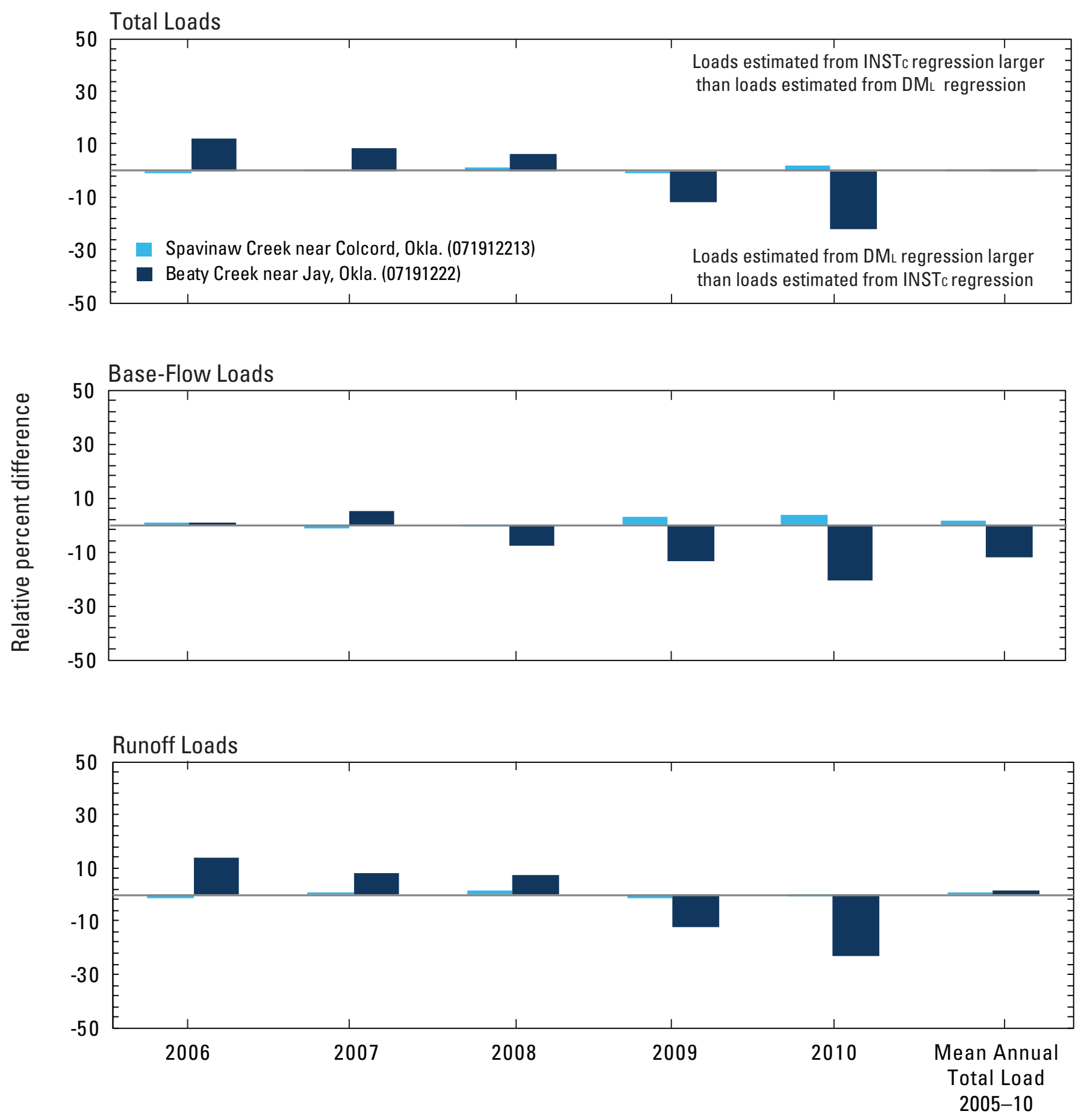

INSTc regression, regression used to estimate concentrations and loads where physical water-quality constituents, streamflow, and seasonality are independent variables.

DM regression, regression used to estimate loads where streamflow, seasonality and time are independent variable.

Figure 11. Comparison of relative percent differences between annual total nitrogen load estimated from two regression methods for Spavinaw Creek near Colcord, Oklahoma, and Beaty Creek near Jay, Okla., streamflow-gaging stations, $2006-10$. 
Estimates of daily nitrogen load generally were greater from the $\mathrm{DM}_{\mathrm{L}}$ regressions than the $\mathrm{INST}_{\mathrm{C}}$ regressions, but differences varied depending on streamflow conditions. For the Colcord station, daily nitrogen loads for base-flow days estimated from the $\mathrm{INST}_{\mathrm{C}}$ regression were significantly greater than the estimates from the $\mathrm{DM}_{\mathrm{L}}$ regression, but daily nitrogen loads on runoff days estimated from the INST $_{C}$ regression were significantly less than the estimates from the $\mathrm{DM}_{\mathrm{L}}$ regression (table 9). Daily nitrogen loads for the Beaty Creek station estimated using the $\mathrm{INST}_{\mathrm{C}}$ regression were significantly less than those estimated using the $\mathrm{DM}_{\mathrm{L}}$ regression under all flow conditions. Load-duration curves indicated that differences in daily load estimates for the two types of regressions were generally small in magnitude (fig. 12). The load-duration curve indicated that nitrogen loads were greater for daily loads estimated from the INST ${ }_{C}$ regression for the largest daily loads (less than 0.3 percent probability of exceedance).
Alternate $\mathrm{INST}_{\mathrm{C}}$ nitrogen regressions that did not include physical water-quality constituents produced a poorer fit to field data than $\mathrm{INST}_{\mathrm{C}}$ nitrogen regressions that did include physical water-quality constituents at both stations (fig. 13). For the Colcord station, the $\mathrm{R}^{2}$ of the alternate $\mathrm{INST}_{\mathrm{C}}$ nitrogen regressions were 0.697 compared to 0.777 percent for INST $_{C}$ nitrogen regressions. Use of water-quality constituents as independent variables only caused a slight improvement in fit for the $\mathrm{INST}_{\mathrm{C}}$ nitrogen regression for the Beaty Creek station, where the $\mathrm{R}^{2}$ of the alternate $\mathrm{INST}_{\mathrm{C}}$ nitrogen regressions was 0.628 compared to 0.647 for the $\mathrm{INST}_{\mathrm{C}}$ nitrogen regression. Graphs of measured and estimated nitrogen concentrations for the alternate $\mathrm{INST}_{\mathrm{C}}$ nitrogen regressions and $\mathrm{INST}_{\mathrm{C}}$ nitrogen regressions at both stations indicated similar distributions of scatter about the one-to-one line, but one larger outlier on the alternate $\mathrm{INST}_{\mathrm{C}}$ regressions at both stations may have decreased the fit of those regressions (fig. 13).

Table 9. Wilcoxon signed-rank test results comparing daily loads estimated from two different regression methods at two streamflowgaging stations in the Eucha-Spavinaw basin, 2004-10.

[INST ${ }_{C}$, estimated instantaneous concentrations, in $\mathrm{mg} / \mathrm{L} ; \mathrm{DM}_{\mathrm{L}}$, daily mean load, in pounds per day; $\mu>0$, mean difference is greater than zero; $\mu<0$, mean difference is less than zero; $p$, probability value; $p$-values in bold indicate statistically significant differences between groups of data at 95 -percent confidence level (probability value less than or equal to 0.05 ); --, not determined]

\begin{tabular}{|c|c|c|c|c|c|c|c|c|c|c|}
\hline \multirow[b]{2}{*}{$\begin{array}{c}\text { Station name } \\
\text { (number) }\end{array}$} & \multirow[b]{2}{*}{$\begin{array}{c}\text { Flow } \\
\text { condition }\end{array}$} & \multicolumn{3}{|c|}{ Nitrogen } & \multicolumn{3}{|c|}{ Phosphorus } & \multicolumn{3}{|c|}{ Suspended sediment } \\
\hline & & $\begin{array}{c}\text { One- } \\
\text { sided } \\
\text { test } \mu>0 \\
\text { p-value }\end{array}$ & $\begin{array}{c}\text { One- } \\
\text { sided } \\
\text { test } \mu<0 \\
\text { p-value }\end{array}$ & $\begin{array}{c}\text { Regression } \\
\text { that } \\
\text { estimated } \\
\text { signifi- } \\
\text { cantly } \\
\text { greater } \\
\text { daily loads }\end{array}$ & $\begin{array}{c}\text { One- } \\
\text { sided } \\
\text { test } \mu>0 \\
\text { p-value }{ }^{1}\end{array}$ & $\begin{array}{c}\text { One- } \\
\text { sided } \\
\text { test } \mu<0 \\
\text { p-value }\end{array}$ & $\begin{array}{l}\text { Regression } \\
\text { that } \\
\text { estimated } \\
\text { signifi- } \\
\text { cantly } \\
\text { greater } \\
\text { daily loads }\end{array}$ & $\begin{array}{c}\text { One- } \\
\text { sided } \\
\text { test } \mu>0 \\
\text { p-value }{ }^{1}\end{array}$ & $\begin{array}{c}\text { One- } \\
\text { sided } \\
\text { test } \mu<0 \\
\text { p-value }{ }^{1}\end{array}$ & $\begin{array}{l}\text { Regression } \\
\text { that } \\
\text { estimated } \\
\text { significant- } \\
\text { ly greater } \\
\text { daily loads }\end{array}$ \\
\hline \multirow{3}{*}{$\begin{array}{l}\text { Spavinaw } \\
\text { Creek near } \\
\text { Colcord, } \\
\text { Okla. } \\
(071912213)\end{array}$} & $\begin{array}{l}\text { Base-flow } \\
\text { days }\end{array}$ & $>0.9999$ & $<0.0001$ & $\mathrm{INST}_{\mathrm{C}}$ & 0.336 & 0.664 & -- & $<0.0001$ & $>0.9999$ & $\mathrm{DM}_{\mathrm{L}}$ \\
\hline & $\begin{array}{r}\text { Runoff } \\
\text { days }\end{array}$ & 0.001 & 0.999 & $\mathrm{DM}_{\mathrm{L}}$ & $<0.0001$ & $>0.9999$ & $\mathrm{DM}_{\mathrm{L}}$ & $<0.0001$ & $>0.9999$ & $\mathrm{DM}_{\mathrm{L}}$ \\
\hline & $\begin{array}{l}\text { High-flow } \\
\text { days }^{2}\end{array}$ & 0.097 & 0.904 & -- & $>0.9999$ & $<0.0001$ & $\mathrm{INST}_{\mathrm{C}}$ & $<0.0001$ & $>0.9999$ & $\mathrm{DM}_{\mathrm{L}}$ \\
\hline \multirow{3}{*}{$\begin{array}{l}\text { Beaty Creek } \\
\text { near Jay, } \\
\text { Okla. } \\
(07191222)\end{array}$} & $\begin{array}{l}\text { Base-flow } \\
\text { days }\end{array}$ & $<0.0001$ & $>0.9999$ & $\mathrm{DM}_{\mathrm{L}}$ & $>0.9999$ & $<0.0001$ & $\mathrm{INST}_{\mathrm{C}}$ & $<0.0001$ & $>0.9999$ & $\mathrm{DM}_{\mathrm{L}}$ \\
\hline & $\begin{array}{r}\text { Runoff } \\
\text { days }\end{array}$ & $<0.0001$ & $>0.9999$ & $\mathrm{DM}_{\mathrm{L}}$ & $<0.0001$ & $>0.9999$ & $\mathrm{DM}_{\mathrm{L}}$ & $<0.0001$ & $>0.9999$ & $\mathrm{DM}_{\mathrm{L}}$ \\
\hline & $\begin{array}{l}\text { High-flow } \\
\text { days }^{2}\end{array}$ & 0.010 & 0.990 & $\mathrm{DM}_{\mathrm{L}}$ & 0.962 & 0.038 & $\mathrm{INST}_{\mathrm{C}}$ & 0.405 & 0.595 & -- \\
\hline
\end{tabular}

${ }^{1}$ Differences greater than zero indicate that daily loads estimated from the $\mathrm{DM}_{\mathrm{L}}$ regression were greater than those estimated from the INST $\mathrm{C}_{\mathrm{C}}$ regression. Differences less than zero indicate that daily loads estimated from the $\mathrm{DM}_{\mathrm{L}}$ regression were less than those estimated from the $\mathrm{INST}_{\mathrm{C}}$ regression.

${ }^{2}$ Days in which daily mean streamflow was greater than the 2-percent streamflow exceedance probability. 


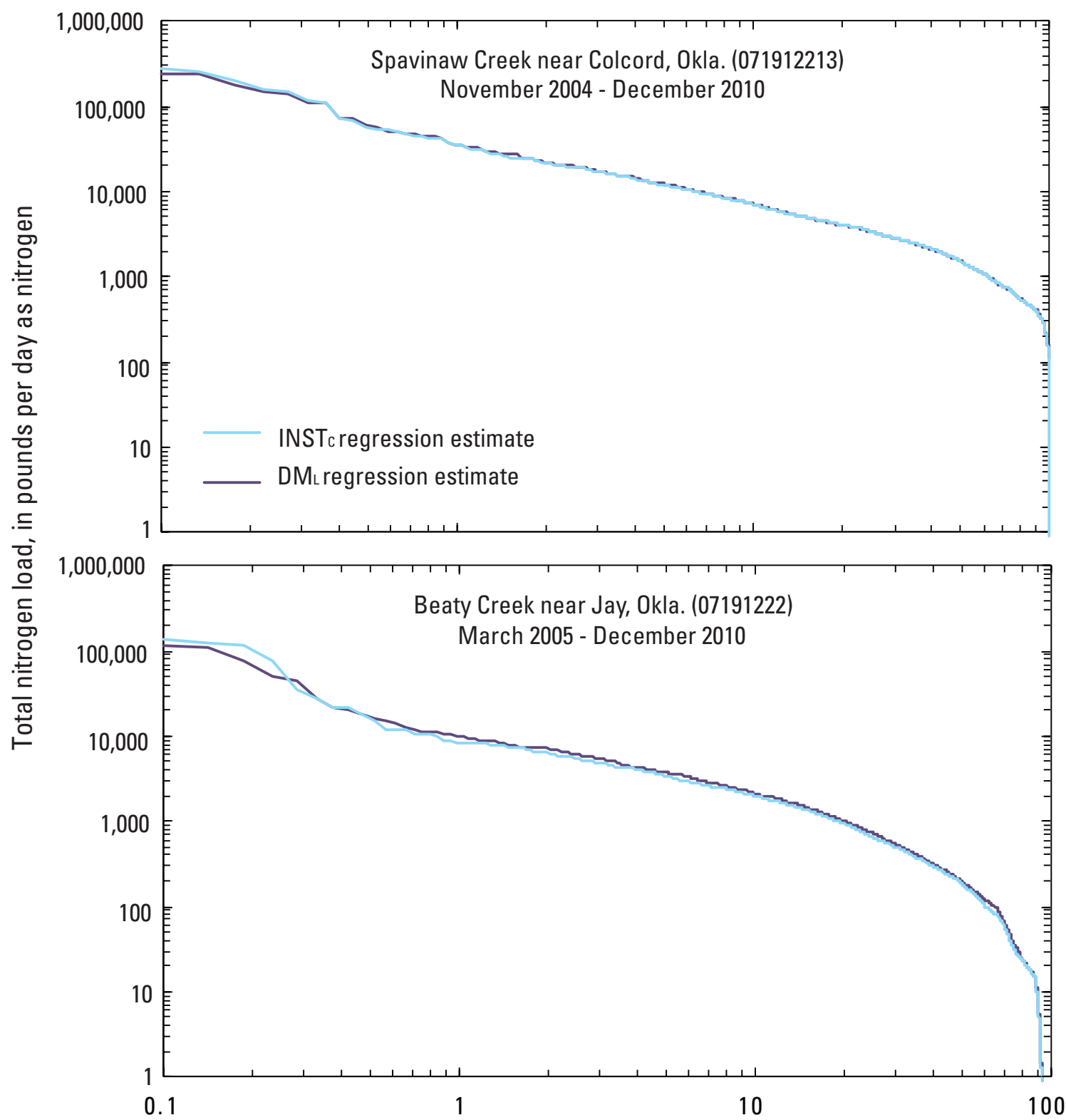

Probability of exceedance, in percent

INSTc regression estimate, daily load computed from estimated concentrations from a regression using physical water-quality constituents, streamflow, and seasonality

DM regression estimate, daily load estimated from a regression using streamflow seasonality, and time 


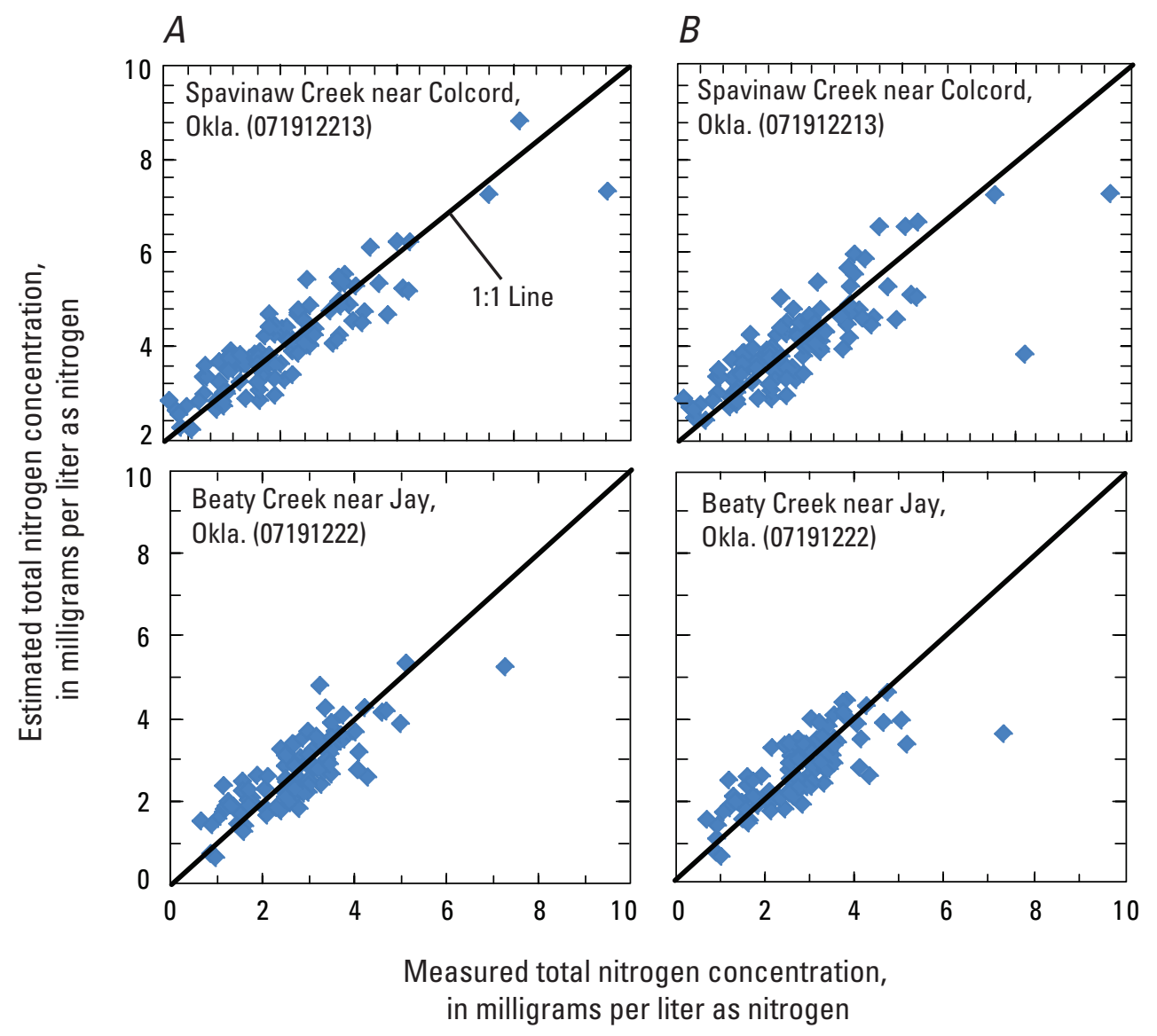

Figure 13. Comparison of measured and regression-estimated total nitrogen concentrations from $(A)$ INST $_{C}$ regressions that include physical water-quality constituents, streamflow, and seasonality as independent variables and $(B)$ alternate INST $_{C}$ regressions that include streamflow and seasonality as independent variables.

\section{Phosphorus}

Mean annual total phosphorus load estimates from the two regression methods did not differ substantially for the Beaty Creek station but were substantially different for the Colcord station (table 8, figs.14-15). The RPD between mean estimated annual total phosphorus loads at the Colcord station was 27.7 percent (fig. 15). In contrast to the Colcord station, the RPD in annual phosphorus total loads at the Beaty Creek station was -2.6 percent (fig. 15). The RPD in mean annual base-flow loads, which composed a relatively small proportion of the total loads (3-10 percent, table 8), was within 7 percent between regressions for data from both stations.

RPDs in annual phosphorus load estimates between the $\mathrm{INST}_{C}$ and $\mathrm{DM}_{\mathrm{L}}$ regressions were variable by year for both stations, and relatively large for some years, ranging from -9.1 to 33.7 percent for the Colcord station and -10.9 to 14.9 for the Beaty Creek station (fig. 15). For the Colcord station, $\mathrm{DM}_{\mathrm{L}}$ total and runoff loads usually were less than $\mathrm{INST}_{\mathrm{C}}$ loads for both stations from 2008 to 2010, equal to INST ${ }_{C}$ loads in 2007, and greater than INST $_{C}$ loads in 2006. Because the years 2008 and 2009 had above-average streamflow and larger annual loads, differences in these years may have caused most of the mean annual differences. Differences in annual loads between the INST $\mathrm{I}_{\mathrm{C}}$ and $\mathrm{DM}_{\mathrm{L}}$ regressions for the Beaty Creek station were variable by year, with no apparent pattern in years with above- or below-average streamflow and differences between annual $\mathrm{DM}_{\mathrm{L}}$ and $\mathrm{INST}_{\mathrm{C}}$ regression loads.

Differences in estimates of daily phosphorus load from both regressions varied substantially for both stations, depending on streamflow conditions. For the Colcord station, daily phosphorus loads estimated from the $\mathrm{INST}_{\mathrm{C}}$ regression were significantly greater than those from the $\mathrm{DM}_{L}$ regression for high-flow days, but daily phosphorus loads estimated from the INST ${ }_{C}$ regression were significantly less than those loads from the $\mathrm{DM}_{\mathrm{L}}$ regression on all runoff days which included extremely high-flow days (table 9). For the Beaty Creek station, daily phosphorus loads estimated from the INST $_{C}$ regression were significantly greater than those from the $\mathrm{DM}_{\mathrm{L}}$ regressions for extremely high-flow days and base-flow 


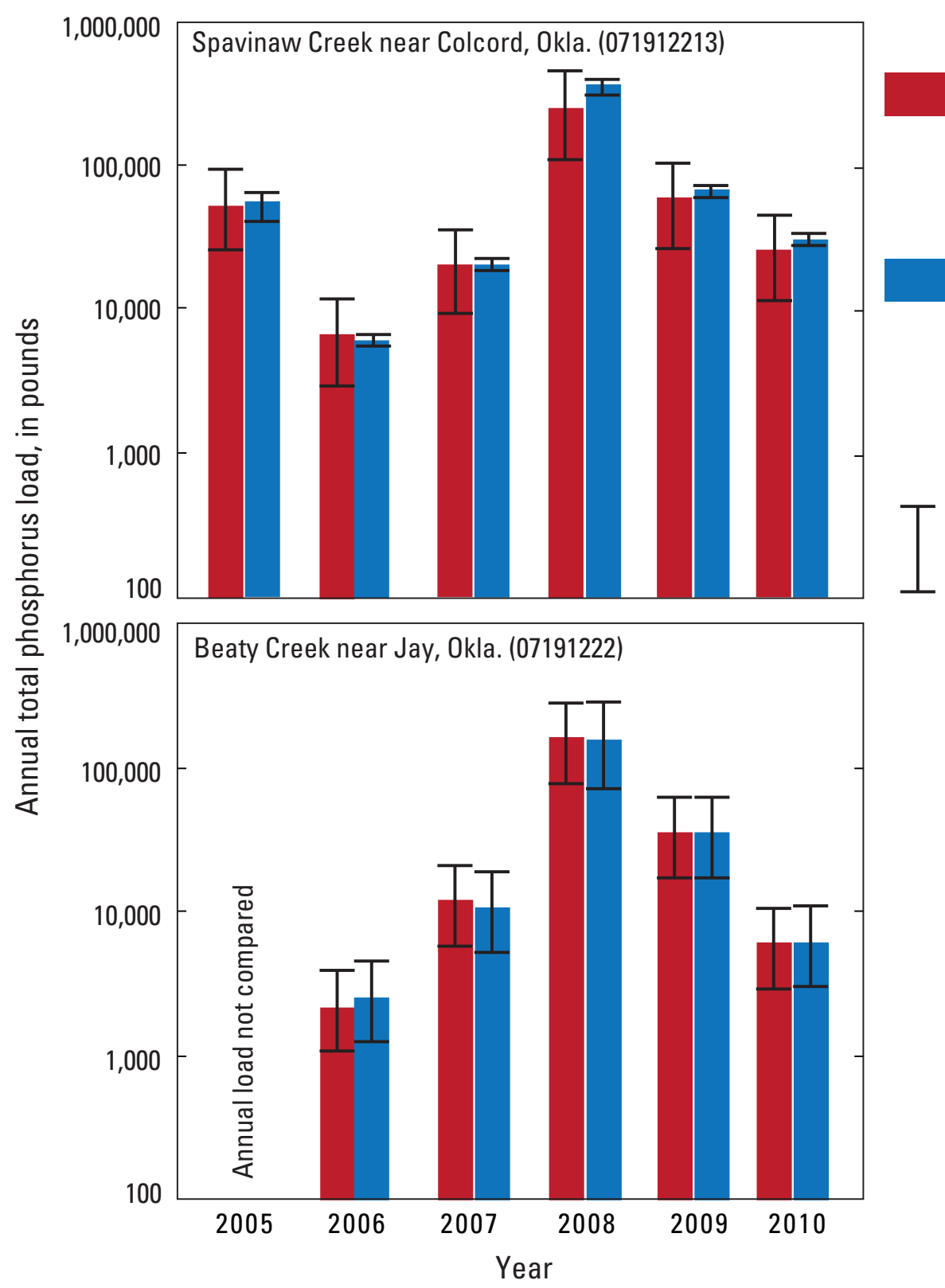

\section{EXPLANATION}

$D M\llcorner$ regression estimate, annual load estimated from a regression using streamflow, seasonality, and time

INST $c$ regression estimate, annual load computed from estimated concentrations from a regression using physical water-quality constituents, streamflow, and seasonality

Estimated upper and lower 90-percent prediction intervals

Figure 14. Annual total phosphorus load estimated using two regression methods at Spavinaw Creek near Colcord, Oklahoma, and Beaty Creek near Jay, Okla., 2005-10. 

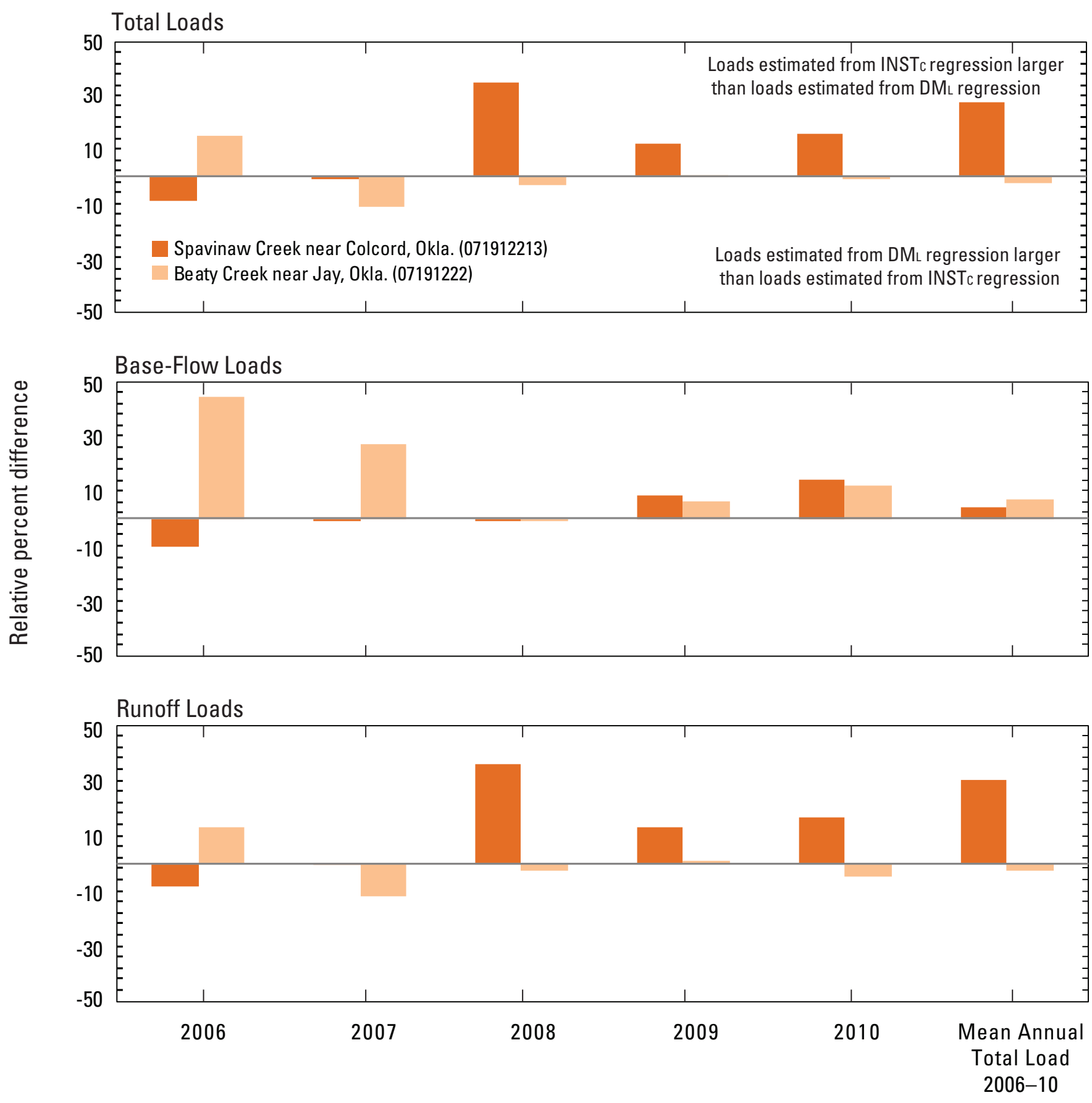

INST $c$ regression, regression used to estimate concentrations and loads where physical water-quality constituents, streamflow, and seasonality are independent variables.

$\mathrm{DM}$ regression, regression used to estimate concentrations and loads where streamflow, seasonality, and time are independent variable.

Figure 15. Bar graphs of comparison of relative percent differences between annual total phosphorus load estimated from two regression methods for Spavinaw Creek near Colcord, Oklahoma, and Beaty Creek near Jay, 0kla., 2006-10. 
days, but daily phosphorus loads estimated from the INST $_{C}$ regression were significantly less than those loads from the $\mathrm{DM}_{\mathrm{L}}$ regression on all runoff days, which included extremely high-flow days (table 9). However, load-duration curves indicated that these differences were small in magnitude for most days except for extremely high-flow days where differences were greater (fig. 16). Extremely high-flow days accounted for 73.4 percent of the total phosphorus load at the Colcord station from November 2004 to December 2010 and 81.8 percent of the total phosphorus load at the Beaty Creek station from March 2005 to December 2010, which indicated that greater daily phosphorus loads estimated from the INST ${ }_{C}$ regressions probably substantially influence total load estimation.

Alternate INST $_{C}$ phosphorus regressions not based on instantaneous measurement of physical properties produced

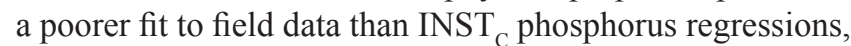
especially for the Colcord station. For the Colcord station, turbidity and streamflow are significantly better estimators of phosphorus than streamflow alone; the $\mathrm{R}^{2}$ of the alternate INST $_{C}$ phosphorus regression was 0.669 (table 7) compared to 0.948 for the INST $_{C}$ phosphorus regression (table 6). This substantial difference in fit may indicate that the INST $_{C}$ regression more accurately estimates load than then $\mathrm{DM}_{\mathrm{L}}$ regression. Use of turbidity only resulted in a slight improvement in fit for the INST $\mathrm{C}_{\mathrm{C}}$ phosphorus regression for the Beaty Creek station, for which the $\mathrm{R}^{2}$ of the alternate $\mathrm{INST}_{\mathrm{C}}$ phosphorus regression was 0.749 compared to 0.791 for INST $_{C}$ regression. Plots of measured and estimated nitrogen concentrations for the alternate $\mathrm{INST}_{\mathrm{C}}$ nitrogen regressions and INST $_{C}$ nitrogen regressions at both stations indicated similar distributions of scatter about the one-toone line, but one substantial outlier on the alternate INST $_{\text {C }}$ phosphorus regression for the Colcord station, which was underestimated by the regression, may have caused poorer fit of that regression (fig. 17).

The $\mathrm{DM}_{\mathrm{L}}$ regression may have substantially underestimated the phosphorus load at the Colcord station in wet years because of poorer fit and use of daily mean streamflow in the $\mathrm{DM}_{\mathrm{L}}$ regression. Differences in fit between INST $_{C}$ and alternate INST $_{C}$ regressions at the Colcord station indicate that the $\mathrm{INST}_{\mathrm{C}}$ regression that included turbidity produced a better fit of annual load estimates than the $\mathrm{DM}_{\mathrm{L}}$ regression that did not include turbidity. In addition to differences in fit, use of daily mean streamflow on days with large runoff may have caused underestimation of daily loads because a disproportionately large amount of the daily phosphorus load was transported at streamflow conditions greater than daily mean streamflow for these days. The days with the largest difference in daily phosphorus load generally also were the days with the largest difference between maximum instantaneous streamflow and mean daily streamflow at the Colcord station (fig. 18). This pattern occurred for both stations but was more apparent at the Colcord station than the Beaty Creek station (fig. 18). However, on January 8, 2008, turbidity readings exceeded the maximum sensor measurement at the Beaty Creek station causing underestimation of load from the $\mathrm{INST}_{\mathrm{C}}$ regression for that day. The three days with the largest differences in daily load at the Colcord station were on March 18-19, and April 10, 2008. However, estimated instantaneous loads were extrapolated for some streamflows for those days because those streamflows were beyond the range used to develop the regression. Collection of additional runoff samples in the future will help to verify these loads and may make a substantial difference in fit of the mean annual phosphorus load.

\section{Sediment}

Mean annual total sediment loads estimated from the $\mathrm{DM}_{\mathrm{L}}$ regression were substantially greater than those estimated from the INST $\mathrm{C}_{\mathrm{C}}$ regression for the Colcord and Beaty Creek stations (table 8, figs. 19-20). The RPD between mean annual total sediment loads at the Colcord station was -38.6 percent for the Colcord station and -122.7 percent for the Beaty Creek station (table 8, fig. 20). RPDs for baseflow loads, which made up a relatively small proportion of total loads (1-33 percent for the Colcord station and about 1 percent for the Beaty Creek station), were -96.6 percent for the Colcord station and 13.1 for the Beaty Creek station.

Differences in annual load estimates between the INST $_{C}$ and $\mathrm{DM}_{\mathrm{L}}$ regressions were variable by year for both stations but generally were less for the $\mathrm{INST}_{\mathrm{C}}$ regression estimates than the $\mathrm{DM}_{\mathrm{L}}$ regression estimates (fig. 20). For the Beaty Creek station, 90 percent prediction intervals were similar for annual total sediment loads estimated for both regressions for all years (fig. 19). RPDs in annual total load ranged from -65.9 to -35.9 percent for the Colcord station and -140 to 6.3 percent for the Beaty Creek station (fig. 20). Differences in annual loads between the $\mathrm{INST}_{\mathrm{C}}$ and $\mathrm{DM}_{\mathrm{L}}$ regressions for the Colcord station were variable by year and had no apparent pattern in years with above- or below-average streamflow. The annual RPD was the greatest in 2008 for the Beaty Creek station (fig. 20).

Estimated daily sediment loads were significantly greater for the $\mathrm{DM}_{\mathrm{L}}$ regressions than the $\mathrm{INST}_{\mathrm{C}}$ regressions for most flow conditions at both stations, with the exception of daily loads for high-flow days at Beaty Creek for which there was no significant difference (table 9). Loadduration curves indicated that these differences were relatively large in magnitude for most days for the Colcord station (fig. 21). The largest difference in daily load between regressions at the Beaty Creek station was on January 8, 2008, which was an order of magnitude in difference $(250,400,000 \mathrm{lbs}$ estimated from the $\mathrm{DM}_{\mathrm{L}}$ regression and 12,360,000 lbs estimated from the INST $_{C}$ regression). The difference in daily loads between regression estimates for that day was 29 percent greater than the annual total load estimated from the $\mathrm{INST}_{\mathrm{C}}$ regression for that year. A possible explanation for this difference may have been the uncertainty in the $\mathrm{INST}_{\mathrm{C}}$ regression estimate for that day. On January 8 , turbidity readings probably exceeded the maximum sensor measurement resulting in underestimation of load for that day. 


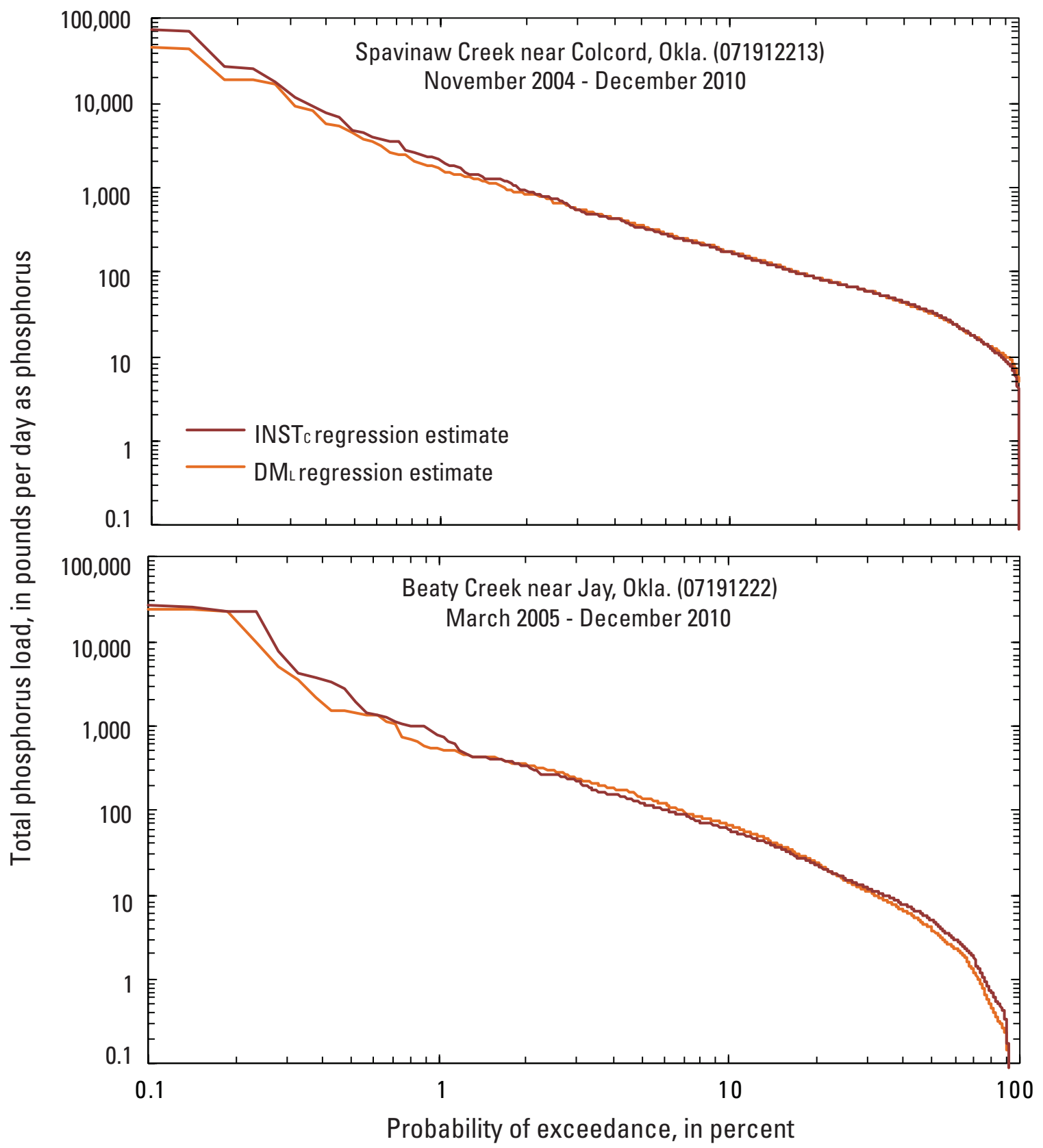

INSTc regression estimate, daily load computed from estimated concentrations from a regression using physical water-quality constituents, streamflow, and seasonality

DM regression estimate, daily load estimated from a regression using streamflow seasonality, and time 


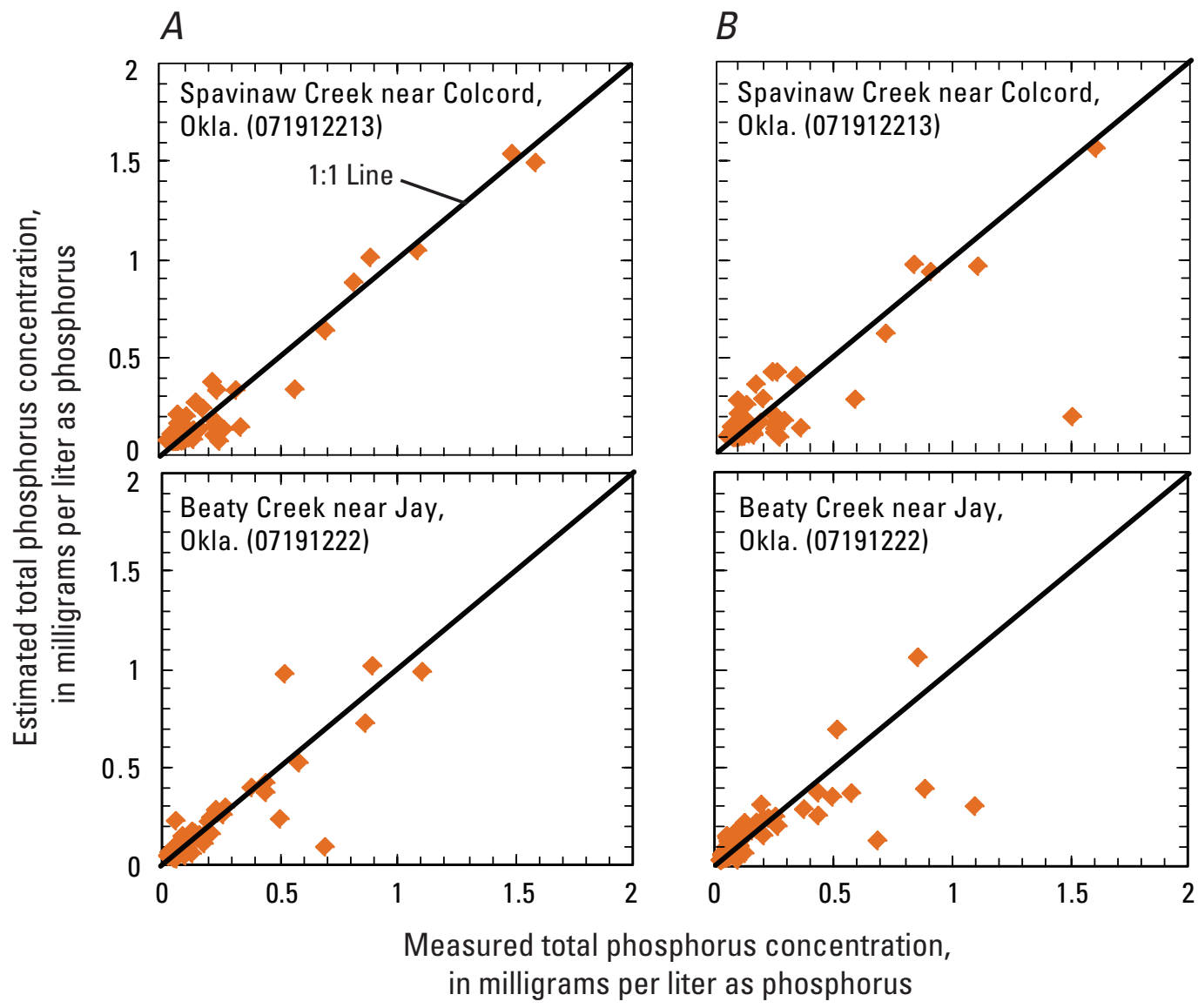

Figure 17. Comparison of measured and regression-estimated total phosphorus concentrations from $(A) I_{\text {INST }}$ regressions based on

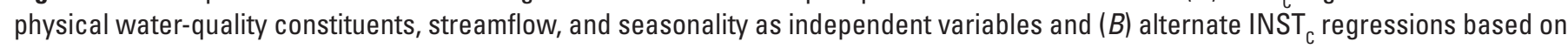
streamflow and seasonality as independent variables. 


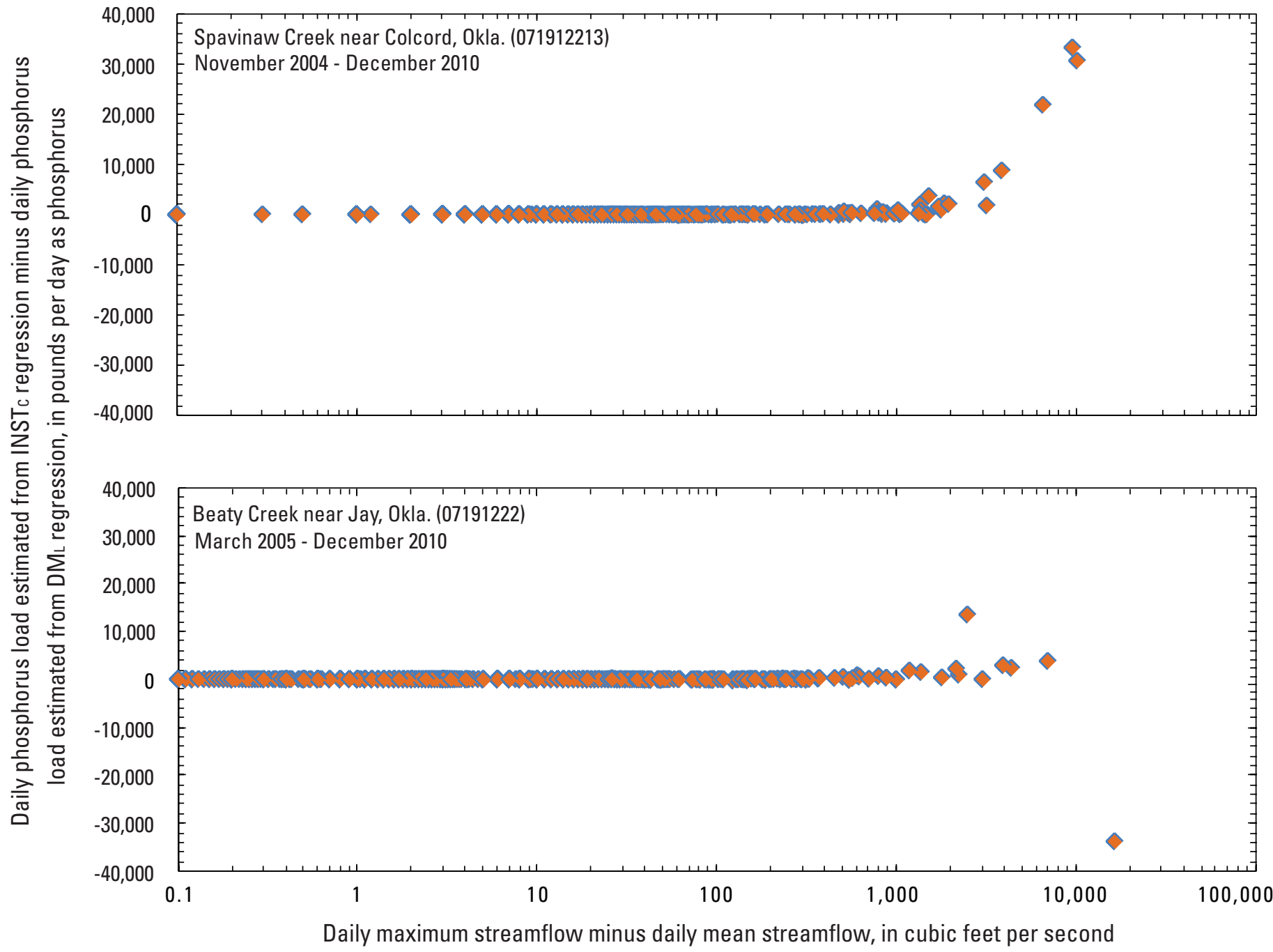

INSTc regression, regression used to estimate concentrations and loads where physical water-quality constituents, streamflow, and seasonality are independent variables.

- DML regression, regression used to estimate loads where streamflow, seasonality, and time are independent variable.

Figure 18. Comparison of difference in daily mean streamflow to difference in estimated phosphorus load between two regression methods at Spavinaw Creek near Colcord, Oklahoma, and Beaty Creek near Jay, Okla. 


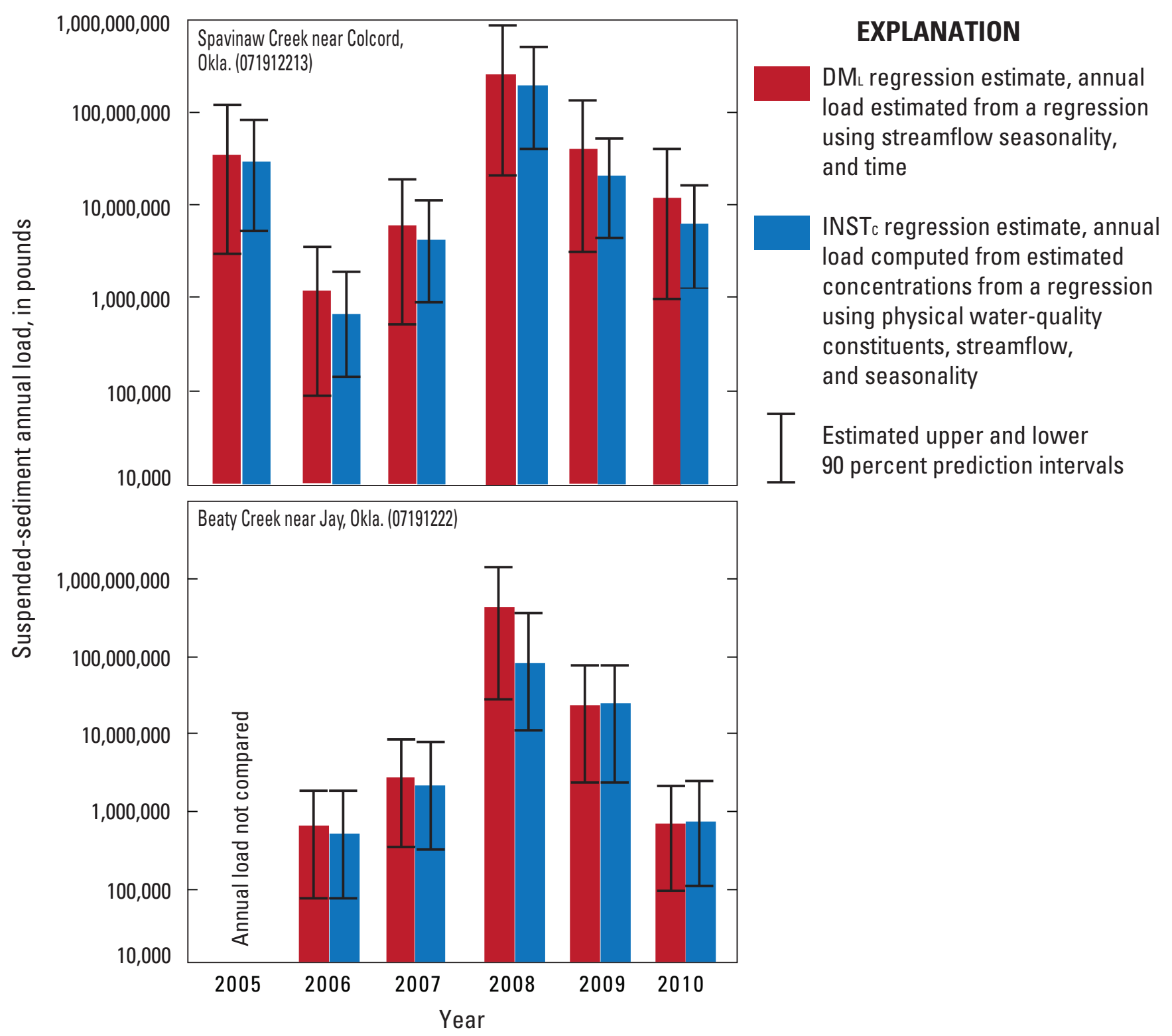

Figure 19. Suspended-sediment annual total load estimated using two regression methods, Spavinaw Creek near Colcord, and Beaty Creek near Jay, Oklahoma, 2005-10. 


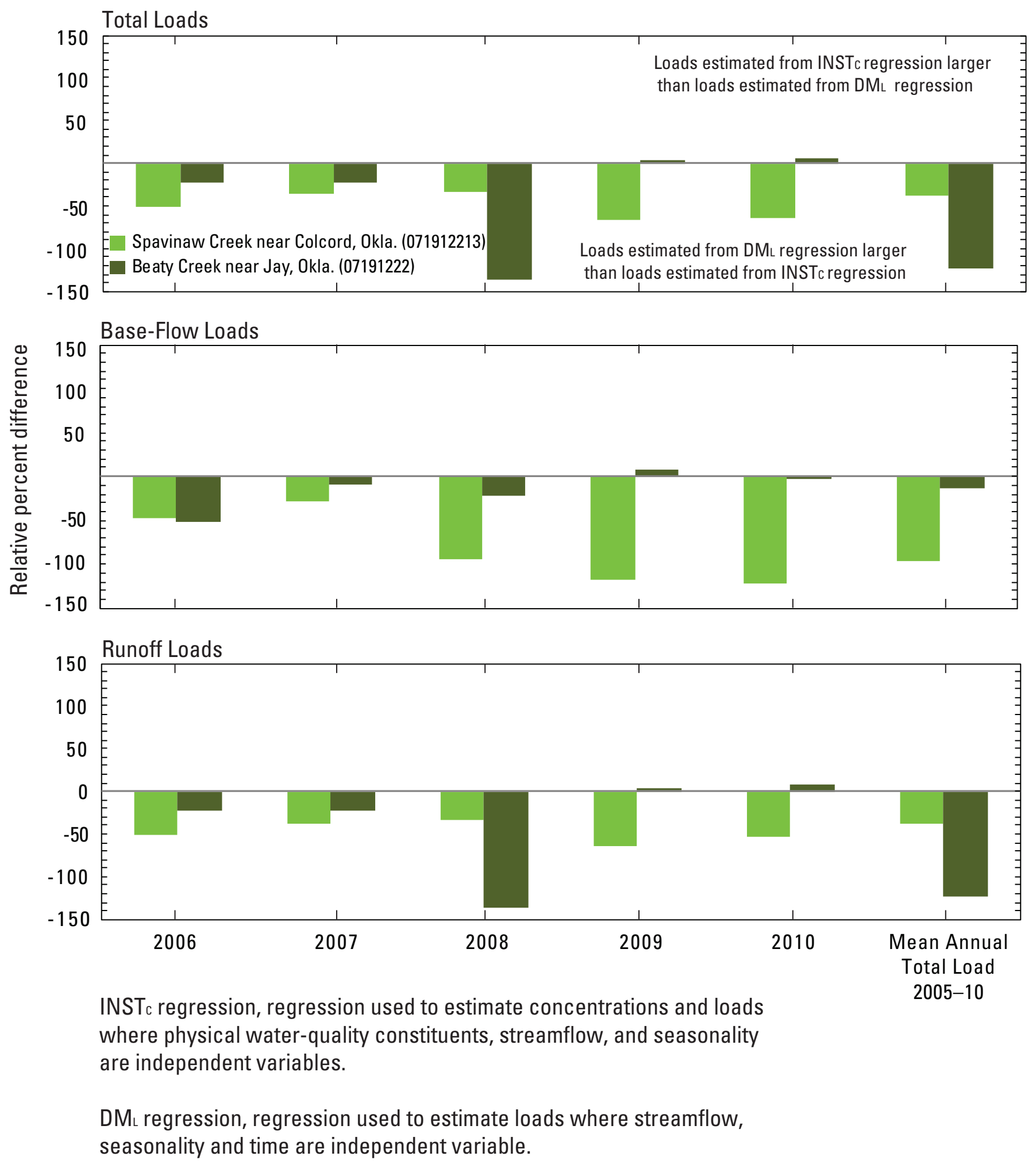

Figure 20. Comparison of relative percent differences between suspended-sediment annual total load estimated from two regression methods for Spavinaw Creek near Colcord, Oklahoma, and Beaty Creek near Jay, Okla., 2006-10. 
44 Nitrogen, Phosphorus, and Suspended Sediment in the Eucha-Spavinaw Basin, 2002-10

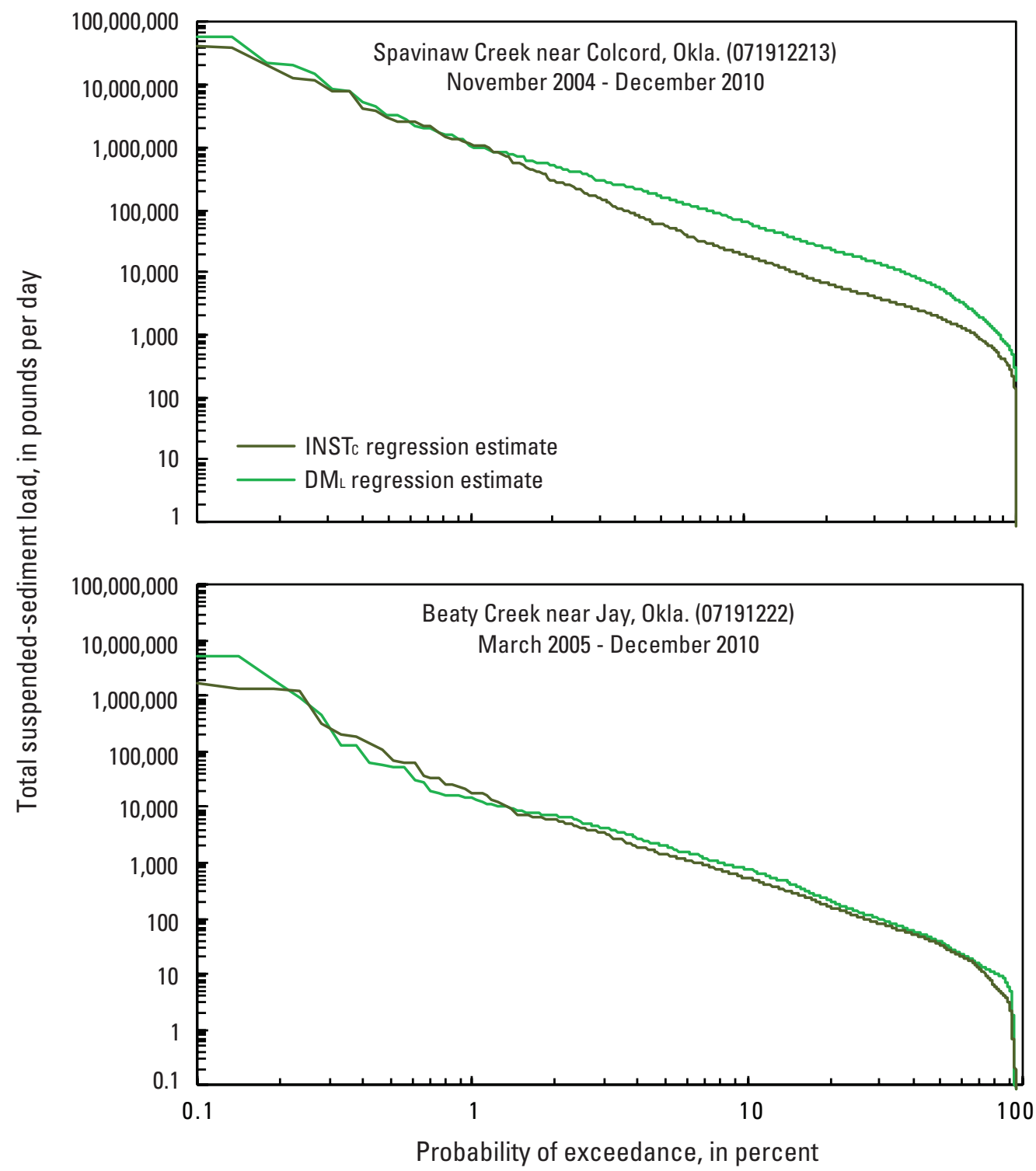

INST c regression estimate, daily load computed from estimated concentrations from a regression using physical water-quality constituents, streamflow, seasonality.

DML regression estimate, daily load estimated from a regression using streamflow seasonality and time.

Figure 21. Comparison of duration curves for estimated daily suspended-sediment loads at Spavinaw Creek near Colcord, Oklahoma, and Beaty Creek near Jay, Okla., streamflow-gaging stations using two regression methods. 
Alternate $\mathrm{INST}_{\mathrm{C}}$ sediment regressions that did not incorporate physical constituent data values produced poorer fits to field data than INST $_{C}$ sediment regressions, especially for the Colcord station. For the Colcord station, turbidity is a substantially better estimator of sediment than streamflow. Streamflow was not a statistically significant estimator of sediment when turbidity was included in the regression. The $\mathrm{R}^{2}$ of the alternate $\mathrm{INST}_{\mathrm{C}}$ sediment regression was 0.549 compared to 0.830 for the $\mathrm{INST}_{\mathrm{C}}$ sediment regression for the Colcord station. Use of turbidity as an independent variable improved the fit for the $\mathrm{INST}_{\mathrm{C}}$ sediment regression for the Beaty Creek station but to a lesser extent for the Colcord station. The $\mathrm{R}^{2}$ of the alternate $\mathrm{INST}_{\mathrm{C}}$ sediment regression was 0.632 compared to 0.757 for $\mathrm{INST}_{\mathrm{C}}$ sediment regression for the Beaty Creek station. Graphs of measured and estimated nitrogen concentrations for the $\mathrm{INST}_{\mathrm{C}}$ sediment regressions at both stations indicated closer distributions of scatter about the one-to-one line compared to the alternate $\mathrm{INST}_{\mathrm{C}}$ regressions (fig. 22). Several substantial outliers on the alternate INST $_{C}$ sediment regression for both stations may have caused poorer fit of those regressions.

Large differences in daily, annual, and mean annual loads between regression methods may be caused by differences in streamflow-estimated sediment load $\left(\mathrm{DM}_{\mathrm{L}}\right.$ regression) compared to turbidity-estimated sediment load (INST ${ }_{C}$ regression). Differences in fit between turbidity-based $\mathrm{INST}_{\mathrm{C}}$ regressions and alternate streamflow-based INST ${ }_{\mathrm{C}}$ regressions indicate that the turbidity-based regression (the $\mathrm{INST}_{\mathrm{C}}$ regression) produced a better fit of load estimate than the $\mathrm{DM}_{\mathrm{L}}$ regression. One possible explanation for overestimation of sediment load from the $\mathrm{DM}_{\mathrm{L}}$ regression is that during large runoff, streamflow is sustained for a longer period of time than turbidity values, causing larger estimates of sediment load from streamflow than from turbidity as described by Rasmussen and others (2005), which compared streamflow-based sediment regressions to turbidity-based sediment regressions.

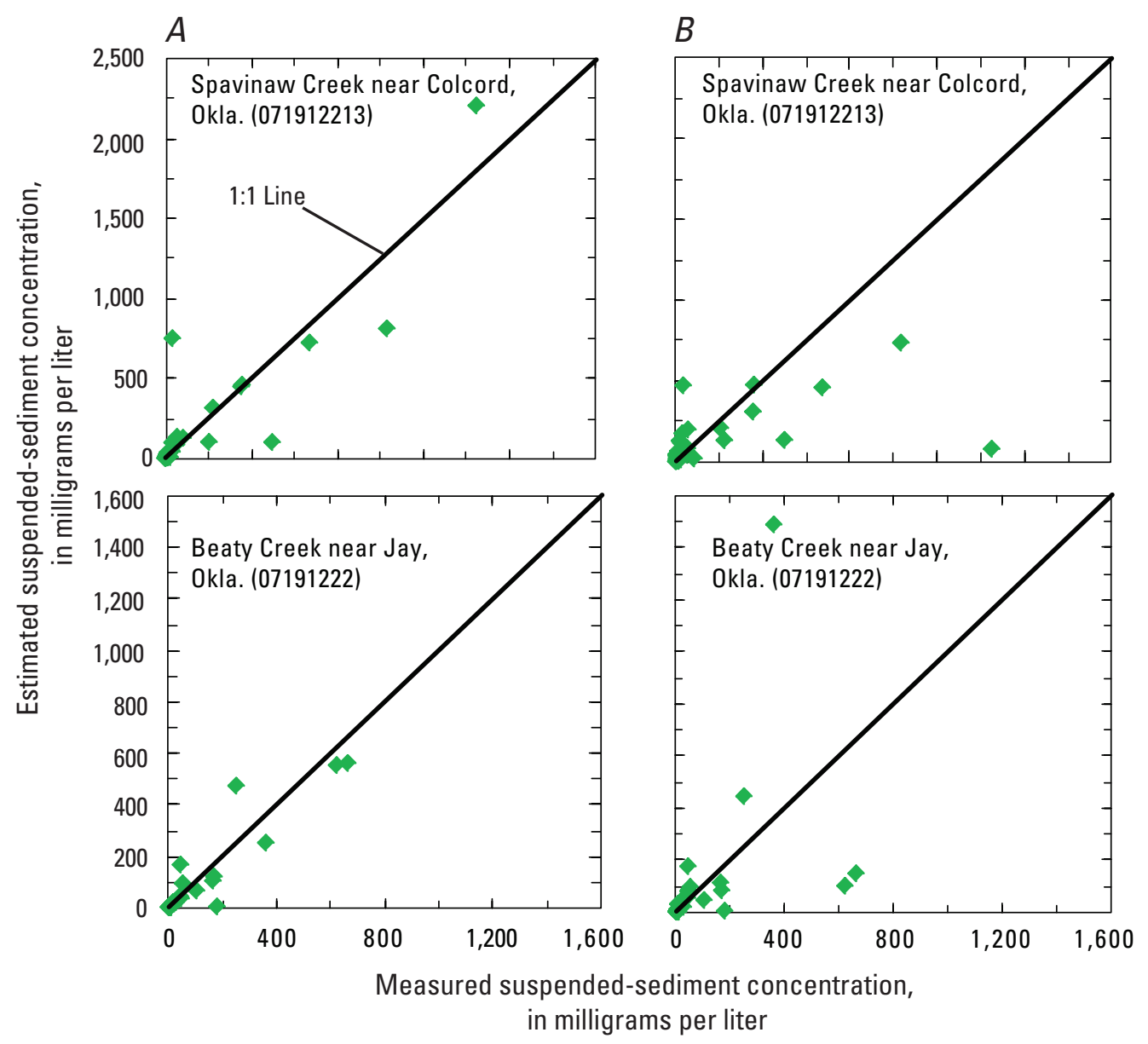

Figure 22. Comparison of measured and regression-estimated suspended-sediment concentrations from $(A)$ INST $_{C}$ regressions based on physical water-quality constituents, streamflow, and seasonality as independent variables and $(B)$ alternate INST $_{C}$ regressions based on streamflow and seasonality as independent variables. 


\section{Evaluation of Temporal Trends in Nitrogen, Phosphorus, and Sediment Concentrations in the Eucha-Spavinaw Basin, 2002-10}

City of Tulsa staff, members of the TMUA Board, and other parties wish to know whether BMPs and other measures have led to improvements in water quality in the EuchaSpavinaw basin. Millions of dollars have been spent to more effectively control discharges of nitrogen and phosphorus compounds from point and nonpoint sources in the basin and in treating drinking water to remove algal chemicals.

No statistically significant temporal trends were detected for flow-adjusted nitrate plus nitrite-nitrogen or total nitrogen concentrations at the five stations. However, there were significant trends in phosphorus concentrations at all stations (table 10, figs. 23-27). Significant downward trends in baseflow phosphorus concentrations were detected at all Spavinaw Creek stations except for the Maysville station, where a slight upward trend (less than $0.01 \mathrm{mg} / \mathrm{L} / \mathrm{yr}$ ) was detected. No trend was detected for base-flow phosphorus concentrations at the Beaty Creek station. Significant downward trends were detected in the phosphorus concentration of runoff samples at all Spavinaw Creek stations except for the Maysville station, where no trend was detected. A slight upward trend for phosphorus concentration $(0.01 \mathrm{mg} / \mathrm{L} / \mathrm{yr}, 4.17$ percent per year) was observed in runoff samples from the Beaty Creek station. Significant upward trends in phosphorus generally were less than significant downward trends in phosphorus. A significant upward trend in phosphorus concentrations from base-flow samples occurred at the Maysville station on Spavinaw Creek (3.5 percent per year), whereas, significant downward trends in phosphorus concentrations ranged from -2.0 to -12.5 percent per year for base-flow samples and from -5.40 to -12.9 percent per year for runoff samples (table 10). There were significant downward trends in phosphorus concentrations in base-flow and runoff samples collected at the Spavinaw Creek near Cherokee City, Sycamore, and Colcord, Okla., streamflow-gaging stations (-4.9 to -12.9 percent per year).

Significant trends in sediment concentrations varied by station and stream. There were significant downward trends in sediment concentration during runoff conditions ranging from -1.53 to -1.81 percent per year at the Maysville, Sycamore, and Beaty Creek stations but no significant trends in sediment concentration during runoff conditions at the Cherokee City or Colcord stations (table 10, figs. 28-30).

Decreased phosphorus content of effluent from the Decatur wastewater-treatment plant following upgrades to the plant in 2006 may have contributed to downward trends in phosphorus concentrations at the three closest downstream
Spavinaw Creek stations. However, the downward trend in phosphorus concentration began prior to the changes in the Decatur wastewater-treatment plant. The trend slopes for baseflow and runoff components of total phosphorus concentration at the Cherokee City station (fig. 24), the station nearest to the Decatur wastewater-treatment plant, were larger (-0.02 and $-0.03 \mathrm{mg} / \mathrm{L} /$ year, respectively) than the trend slopes of phosphorus concentrations at the downstream stations (table 10). Decreases in phosphorus concentrations during runoff as well as base-flow conditions also were measured at the stations further downstream from the wastewatertreatment plants. In streams affected by wastewater discharge, streambed sediments can act as phosphorus storage zones (Haggard and others, 2001) and are a source of phosphorus to downstream locations (Reddy and others, 1999; Haggard and Stoner, 2009). Therefore, mobilization of streambed sediments during runoff conditions may coincide with transport of phosphorus sorbed to those sediments. Decreased phosphorus concentrations in runoff samples may have been caused by decreases in phosphorus content of sediments in Columbia Hollow downstream from the plant (fig. 1). However, the largest decreases in phosphorus concentrations occurred prior to reductions in phosphorus from the Decatur wastewater-treatment plant in 2006, which indicates that the observed trends are not solely explained by improvements to the plant (figs. 24-26).

Other possible explanations for significant downward trends in phosphorus may be consequences of BMP implementation and reduction in poultry-litter applications, but these explanations were not supported by the trend analysis because downward trends in phosphorus concentrations were not observed at the Maysville or Beaty Creek stations (figs. 23 and 27), even though BMPs were implemented in the basins upstream from those stations. BMPs were not implemented in much of the Spavinaw basin until 2003. BMPs were implemented in the Beaty Creek basin in 1998; however, a slight upward trend in phosphorus concentration was detected for that station (fig. 27, table 10).

Runoff samples collected at the Beaty Creek station had a statistically significant upward trend in phosphorus concentrations and a significant downward trend in sediment concentration (table 10), indicating that the amount of phosphorus sorbed to sediment during runoff may have increased with time even though sediment concentrations decreased or that the dissolved component of phosphorus increased relative to the sediment-sorbed component. BMPs implemented in Beaty Creek basin from 1998 to 2003 may have caused decreases in sediment transport from hilltops or streambanks. However, BMPs may not have caused decreases in phosphorus concentrations because long-term phosphorus storage in channel sediments may be a persistent source of phosphorus in the future (Phillips and others, 2005). 
Table 10. Results of Kendall's tau and Seasonal Kendall tests of time trends of concentrations of nitrate plus nitrite, total nitrogen, total phosphorus, and suspended sediment in water samples collected at streamflow-gaging stations in the Eucha-Spavinaw basin, Arkansas and Oklahoma, 2002-10.

[Tau, Kendall's tau; P-Value, probability level; SK, Seasonal Kendall trend test; KT, Kendall-Thiel trend test; results shaded in blue are statistically significant upward trends at a p-value of 0.05 ; results shaded in green are statistically significant downward trends at a p-value of less than or equal to 0.05 ; --, not reported]

\begin{tabular}{|c|c|c|c|c|c|c|c|c|c|c|c|c|}
\hline \multirow[b]{2}{*}{ Constituent } & \multicolumn{6}{|c|}{ Base flow } & \multicolumn{6}{|c|}{ Runoff } \\
\hline & $\begin{array}{l}\text { Trend } \\
\text { test }^{1}\end{array}$ & $\begin{array}{c}\text { Flow } \\
\text { adjust- } \\
\text { ment }^{2}\end{array}$ & Tau & $\begin{array}{c}\text { p- } \\
\text { value }\end{array}$ & $\begin{array}{c}\text { Slope } \\
\text { (mg/L/ } \\
\text { yr) }\end{array}$ & $\begin{array}{c}\text { Slope } \\
\text { (percent/yr) }\end{array}$ & $\begin{array}{l}\text { Trend } \\
\text { test }^{1}\end{array}$ & $\begin{array}{c}\text { Flow } \\
\text { adjust- } \\
\text { ment }^{2}\end{array}$ & Tau & $\begin{array}{c}\text { P- } \\
\text { value }\end{array}$ & $\begin{array}{c}\text { Slope } \\
\text { (mg/L/yr) }\end{array}$ & $\begin{array}{c}\text { Slope } \\
\text { (percent/yr) }\end{array}$ \\
\hline \multicolumn{13}{|c|}{ Spavinaw Creek near Maysville, Ark. (07191160) } \\
\hline $\begin{array}{l}\text { Total nitrate plus } \\
\text { nitrite }\end{array}$ & SK & yes & -0.074 & 0.631 & -- & -- & SK & no & 0.230 & 0.213 & -- & -- \\
\hline Total nitrogen & SK & yes & -0.015 & 0.955 & -- & -- & SK & yes & 0.149 & 0.393 & -- & -- \\
\hline Total phosphorus & SK & no & +0.313 & 0.020 & $<0.01$ & +3.5 & SK & yes & 0.080 & 0.649 & -- & -- \\
\hline $\begin{array}{l}\text { Suspended } \\
\text { sediment }\end{array}$ & \multicolumn{6}{|c|}{ not analyzed } & KT & yes & -0.280 & 0.009 & -2.7 & -1.53 \\
\hline \multicolumn{13}{|c|}{ Spavinaw Creek near Cherokee City, Ark. (07191179) } \\
\hline $\begin{array}{l}\text { Total nitrate plus } \\
\text { nitrite }\end{array}$ & SK & yes & -0.203 & 0.309 & -- & -- & SK & yes & 0.192 & 0.168 & -- & -- \\
\hline Total nitrogen & SK & yes & -0.188 & 0.325 & -- & -- & SK & yes & 0.131 & 0.386 & -- & -- \\
\hline Total phosphorus & SK & yes & -0.800 & 0.003 & -0.02 & -12.5 & SK & yes & -0.613 & 0.006 & -0.03 & -12.9 \\
\hline $\begin{array}{r}\text { Suspended } \\
\text { sediment }\end{array}$ & \multicolumn{6}{|c|}{ not analyzed } & KT & yes & -0.112 & 0.303 & -- & -- \\
\hline \multicolumn{13}{|c|}{ Spavinaw Creek near Sycamore, Okla. (07191220) } \\
\hline $\begin{array}{l}\text { Total nitrate plus } \\
\text { nitrite }\end{array}$ & KT & yes & -0.027 & 0.814 & -- & -- & SK & yes & 0.218 & 0.118 & -- & -- \\
\hline Total nitrogen & $\mathrm{KT}$ & yes & -0.026 & 0.825 & -- & -- & SK & yes & 0.172 & 0.179 & -- & -- \\
\hline Total phosphorus & KT & no & -0.604 & $<0.001$ & $<0.01$ & -2.0 & SK & yes & -0.540 & 0.027 & -0.01 & -5.40 \\
\hline $\begin{array}{l}\text { Suspended } \\
\text { sediment }\end{array}$ & \multicolumn{6}{|c|}{ not analyzed } & KT & yes & -0.251 & 0.023 & -2.7 & -1.81 \\
\hline \multicolumn{13}{|c|}{ Spavinaw Creek near Colcord, Okla. (071912213) } \\
\hline $\begin{array}{l}\text { Total nitrate plus } \\
\text { nitrite }\end{array}$ & SK & yes & -0.233 & 0.201 & -- & -- & SK & yes & 0.161 & 0.098 & -- & -- \\
\hline Total nitrogen & SK & yes & -0.267 & 0.168 & -- & -- & SK & yes & 0.097 & 0.579 & -- & -- \\
\hline Total phosphorus & SK & no & -0.451 & 0.010 & $<0.01$ & -4.9 & SK & yes & -0.441 & 0.016 & -0.02 & -6.53 \\
\hline $\begin{array}{l}\text { Suspended } \\
\text { sediment }\end{array}$ & \multicolumn{6}{|c|}{ not analyzed } & KT & yes & -0.159 & 0.092 & -- & \\
\hline
\end{tabular}

\begin{tabular}{|c|c|c|c|c|c|c|c|c|c|c|c|c|}
\hline \multicolumn{13}{|c|}{ Beaty Creek near Jay, Okla. (07191222) } \\
\hline $\begin{array}{l}\text { Total nitrate plus } \\
\text { nitrite }\end{array}$ & SK & yes & 0.086 & 0.681 & -- & -- & SK & yes & 0.213 & 0.234 & -- & -- \\
\hline Total nitrogen & SK & yes & 0.061 & 0.812 & -- & -- & SK & yes & 0.191 & 0.224 & -- & -- \\
\hline Total phosphorus & SK & yes & 0.357 & 0.055 & -- & -- & SK & yes & +0.330 & 0.039 & +0.01 & +4.17 \\
\hline $\begin{array}{l}\text { Suspended } \\
\text { sediment }\end{array}$ & \multicolumn{6}{|c|}{ not analyzed } & KT & yes & -0.270 & 0.004 & -1.5 & -1.59 \\
\hline
\end{tabular}

${ }^{1}$ Kendall-Thiel trend test used when adequate seasons could not be defined for use in Seasonal Kendall trend test according to standard thresholds discussed in Schertz and others (1991).

${ }^{2}$ Flow-adjustment was only applied if concentrations in the given dataset were significantly correlated to streamflow at the time of sample collection at a p-value of less than or equal to 0.05 . 

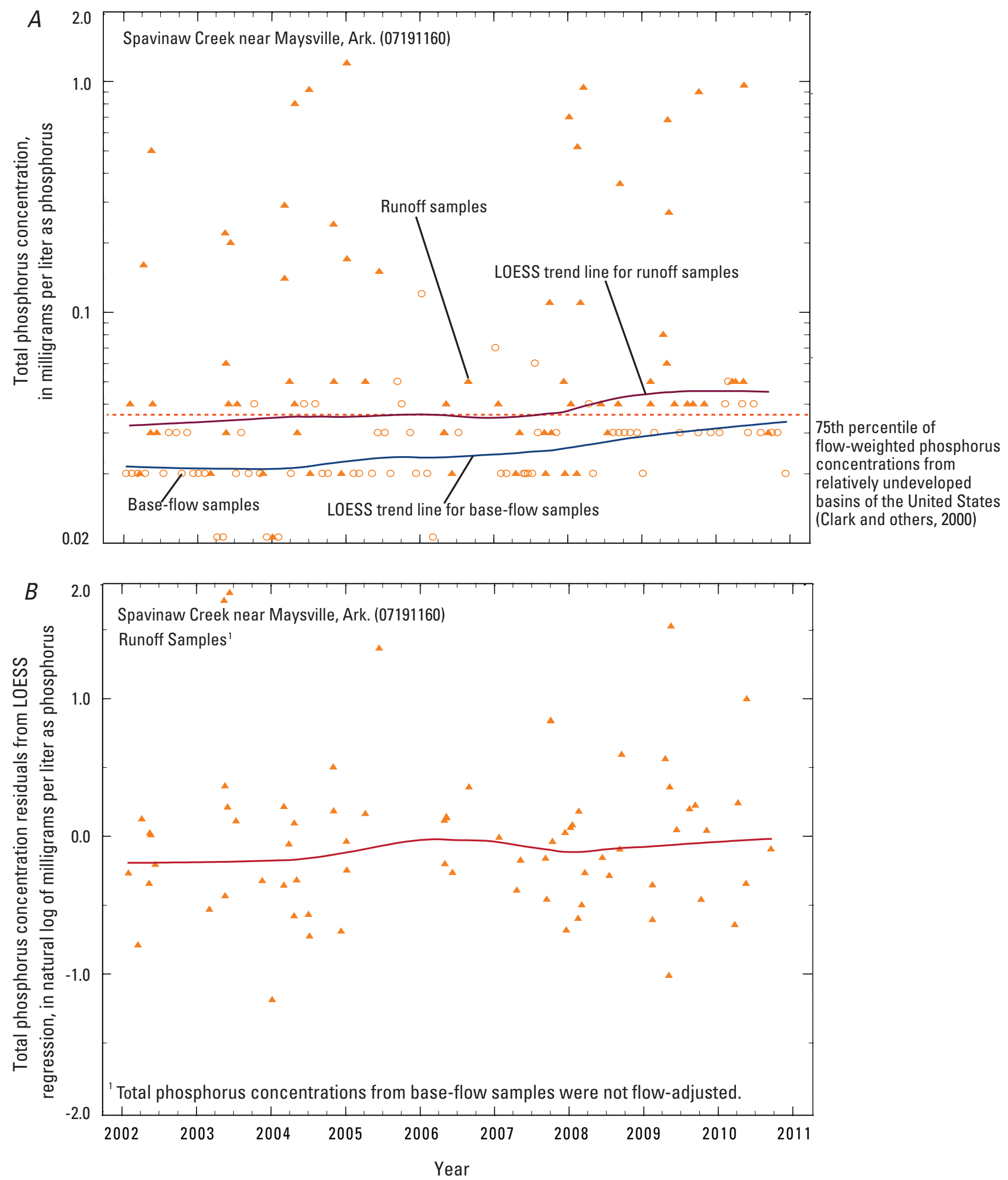

Figure 23. Phosphorus concentrations and LOESS trend lines at Spavinaw Creek near Maysville, Arkansas, showing $(A)$ total phosphorus concentrations with time, and $(B)$ flow-adjusted total phosphorus concentrations (error residuals) from a LOESS regression. 

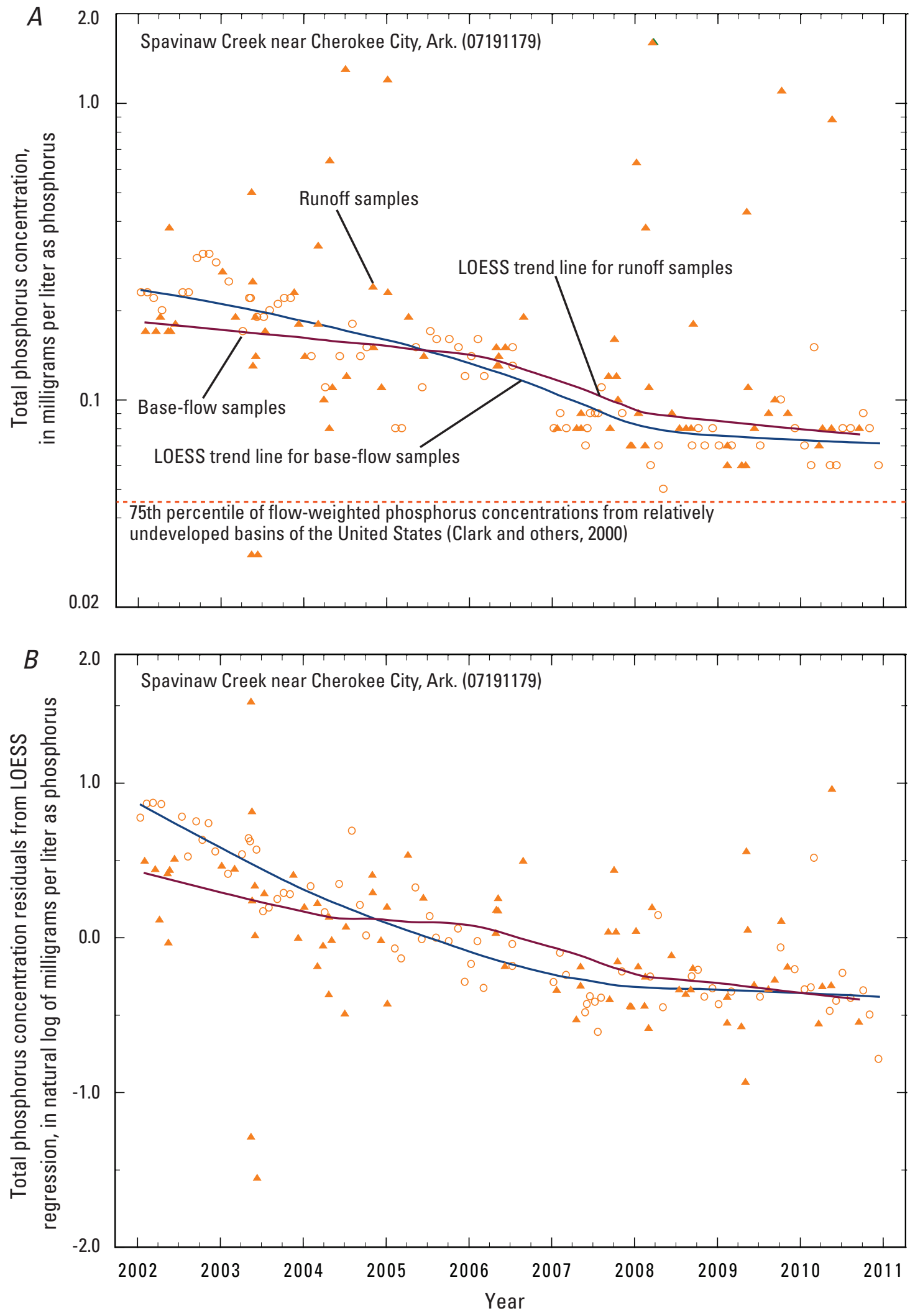

Figure 24. Total phosphorus concentrations and LOESS trend lines at Spavinaw Creek near Cherokee City, Arkansas, showing $(A)$ total phosphorus concentrations with time, and ( $B$ ) flow-adjusted total phosphorus concentrations (error residuals) from a LOESS regression. 

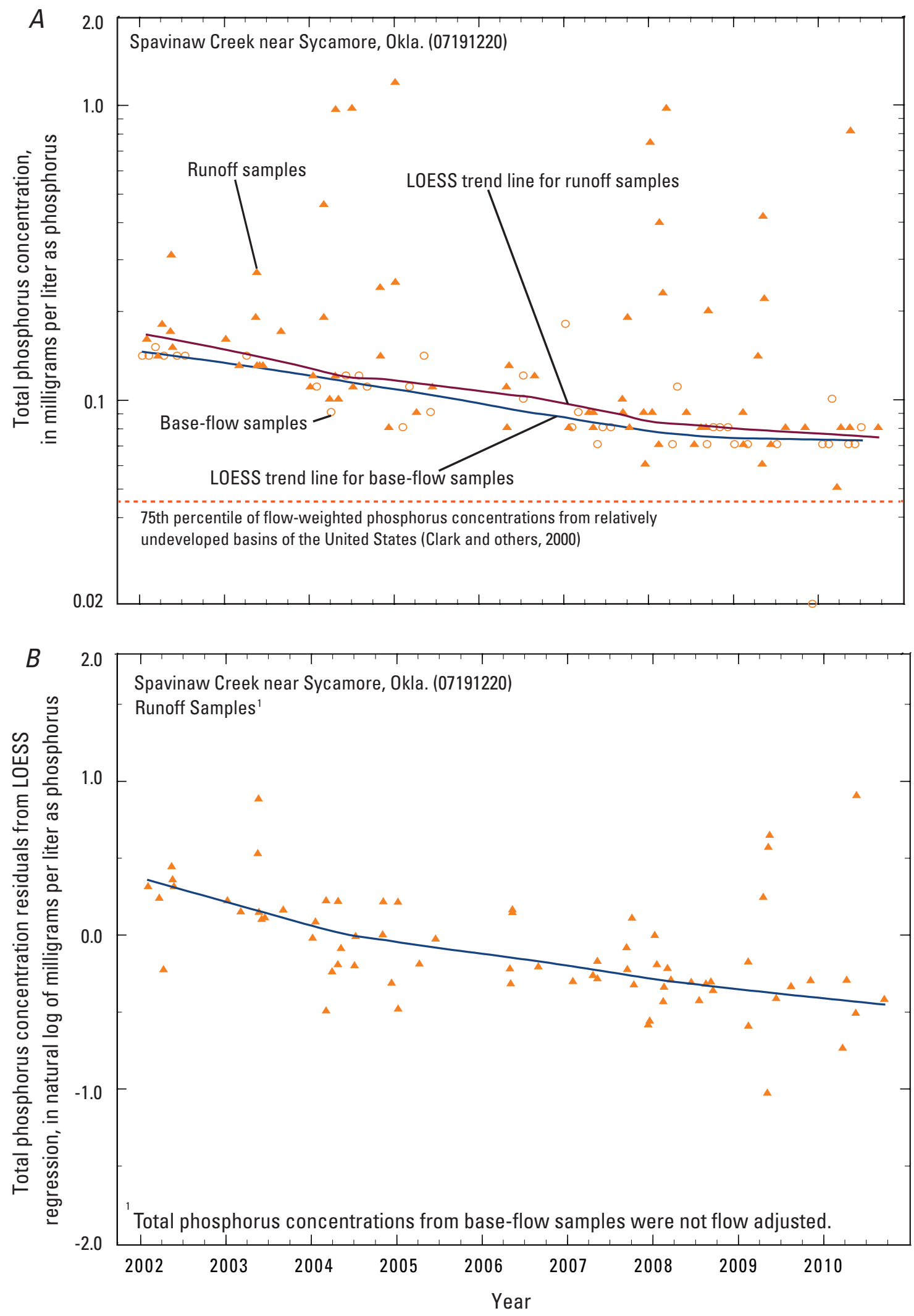

Figure 25. Total phosphorus concentrations and LOESS trend lines at Spavinaw Creek near Sycamore, Oklahoma, showing $(A)$ total phosphorus concentrations with time, and ( $B$ ) flow-adjusted total phosphorus concentrations (error residuals) from a LOESS regression. 

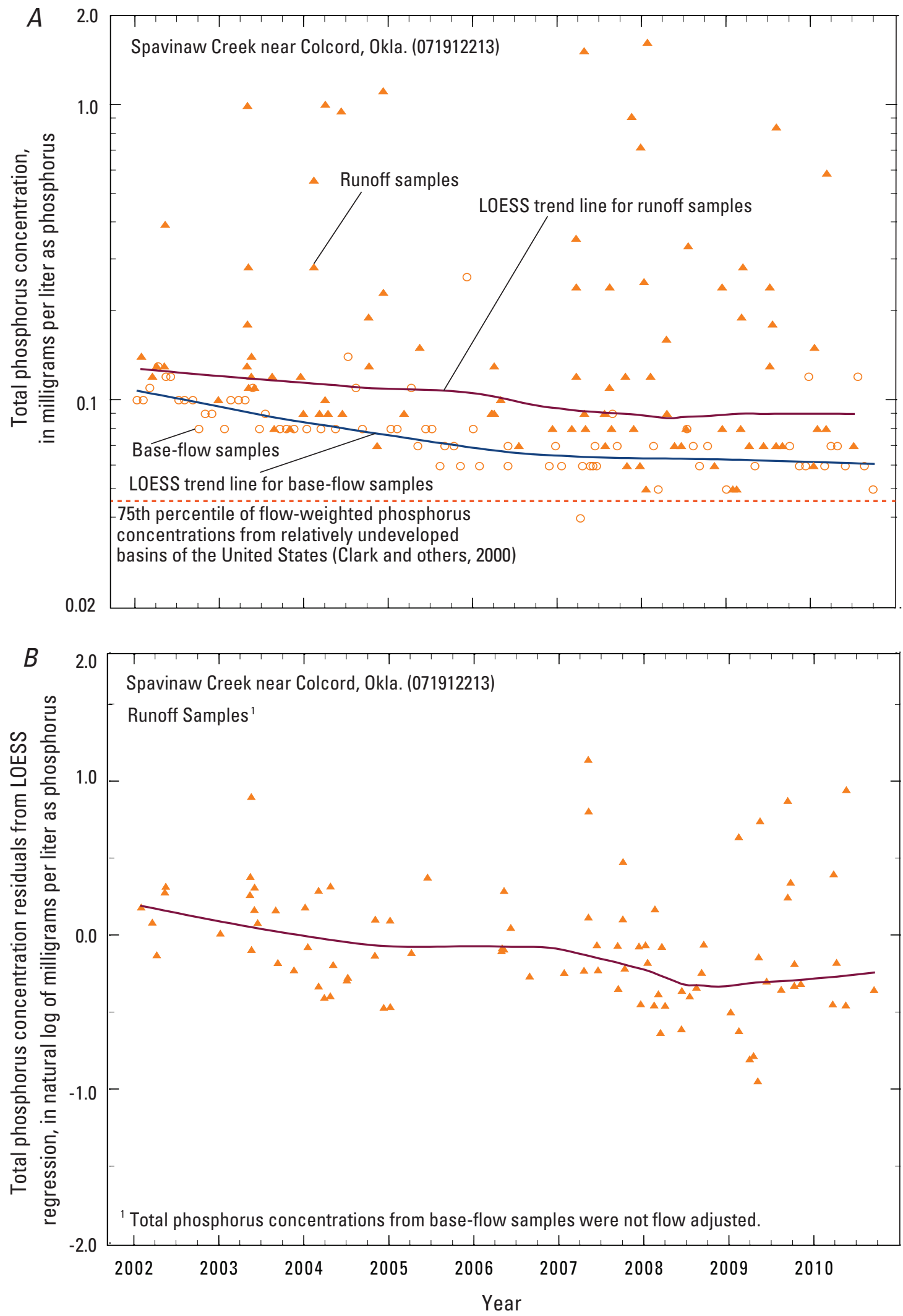

Figure 26. Total phosphorus concentrations and LOESS trend lines at Spavinaw Creek near Colcord, Oklahoma, showing $(A)$ total phosphorus concentrations with time, and (B) flow-adjusted total phosphorus concentrations (error residuals) from a LOESS regression. 

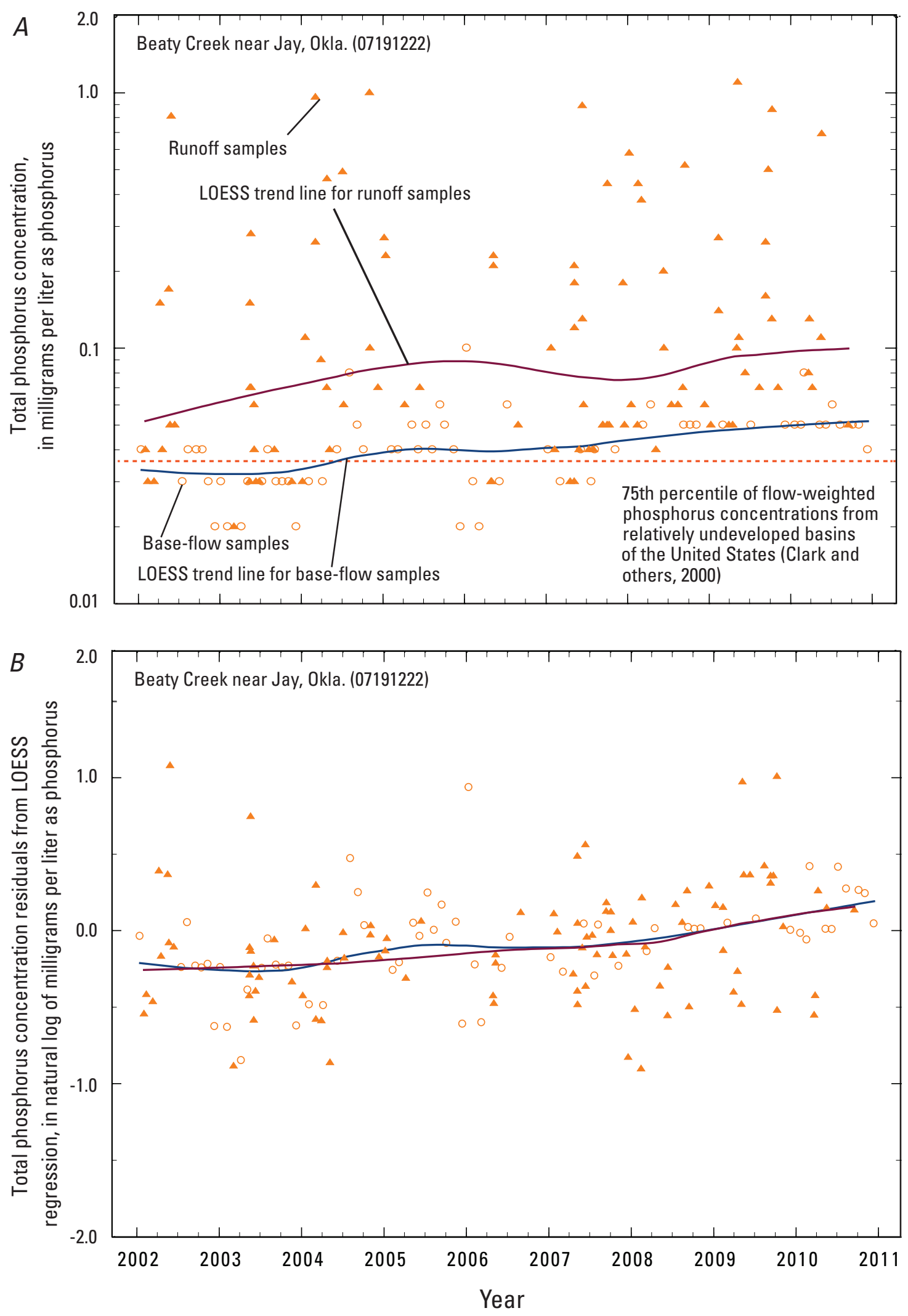

Figure 27. Total phosphorus concentrations and LOESS trend lines at Beaty Creek near Jay, Oklahoma, showing $(A)$ total phosphorus concentrations with time, and $(B)$ flow-adjusted total phosphorus concentrations (error residuals) from a LOESS regression. 

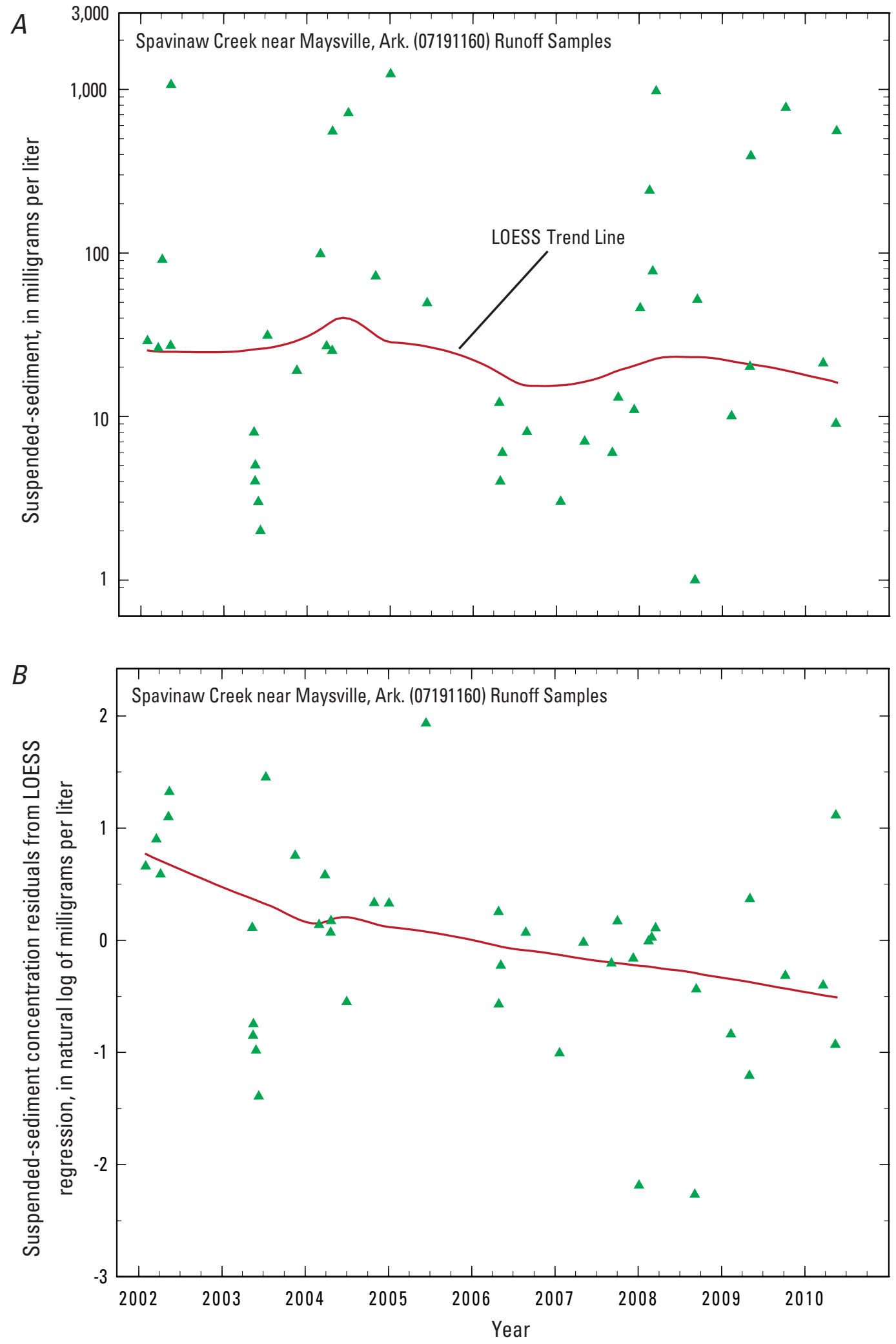

Figure 28. Suspended-sediment concentrations and LOESS trend lines at Spavinaw Creek near Maysville, Arkansas, showing $(A)$ suspended-sediment concentrations with time, and (B) flow-adjusted suspended-sediment concentrations (error residuals) from a LOESS regression. 

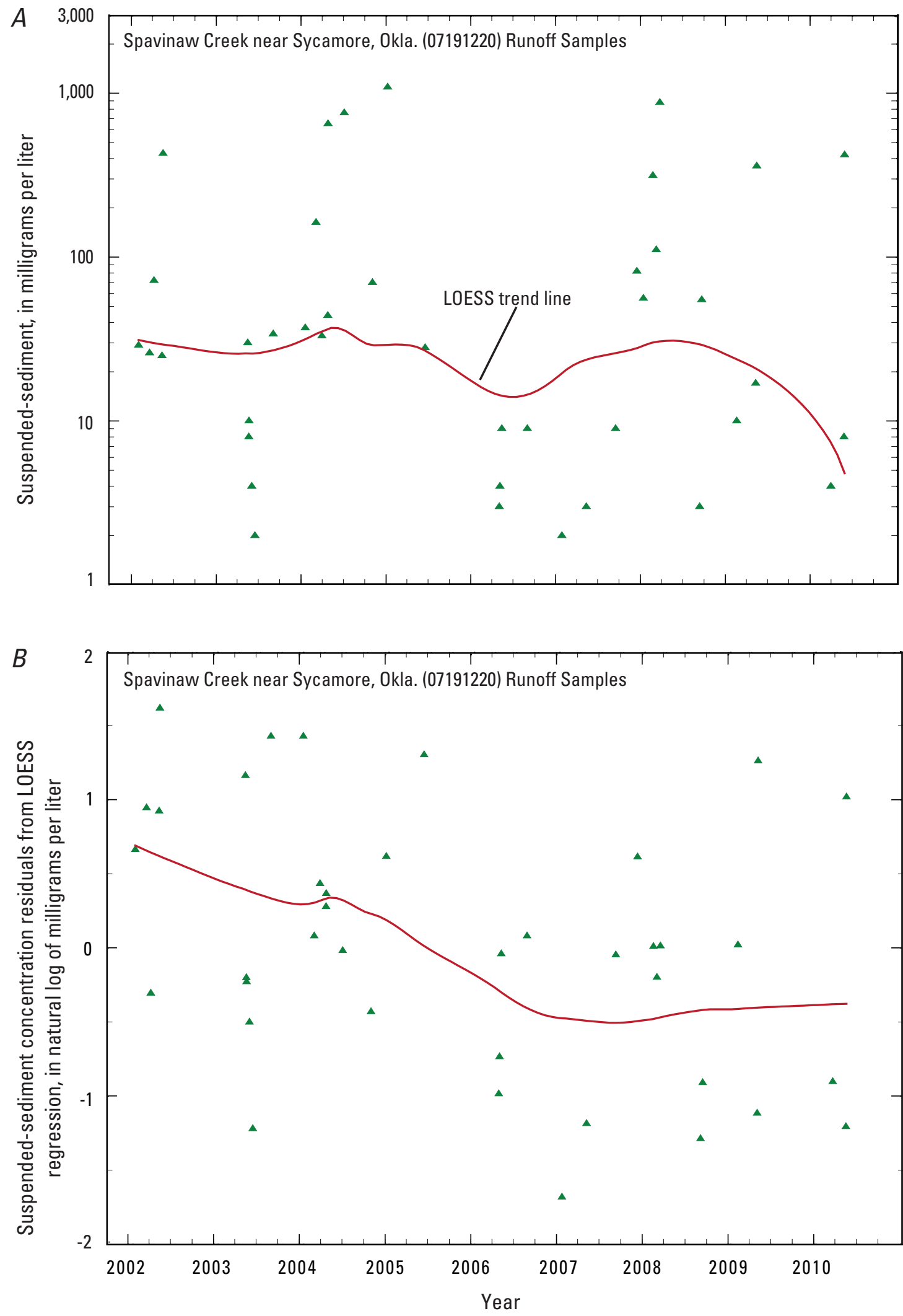

Figure 29. Suspended-sediment concentrations and LOESS trend lines at Spavinaw Creek near Sycamore, Oklahoma, showing $(A)$ suspended-sediment concentrations with time, and $(B)$ flow-adjusted suspended-sediment concentrations (error residuals) from a LOESS regression. 

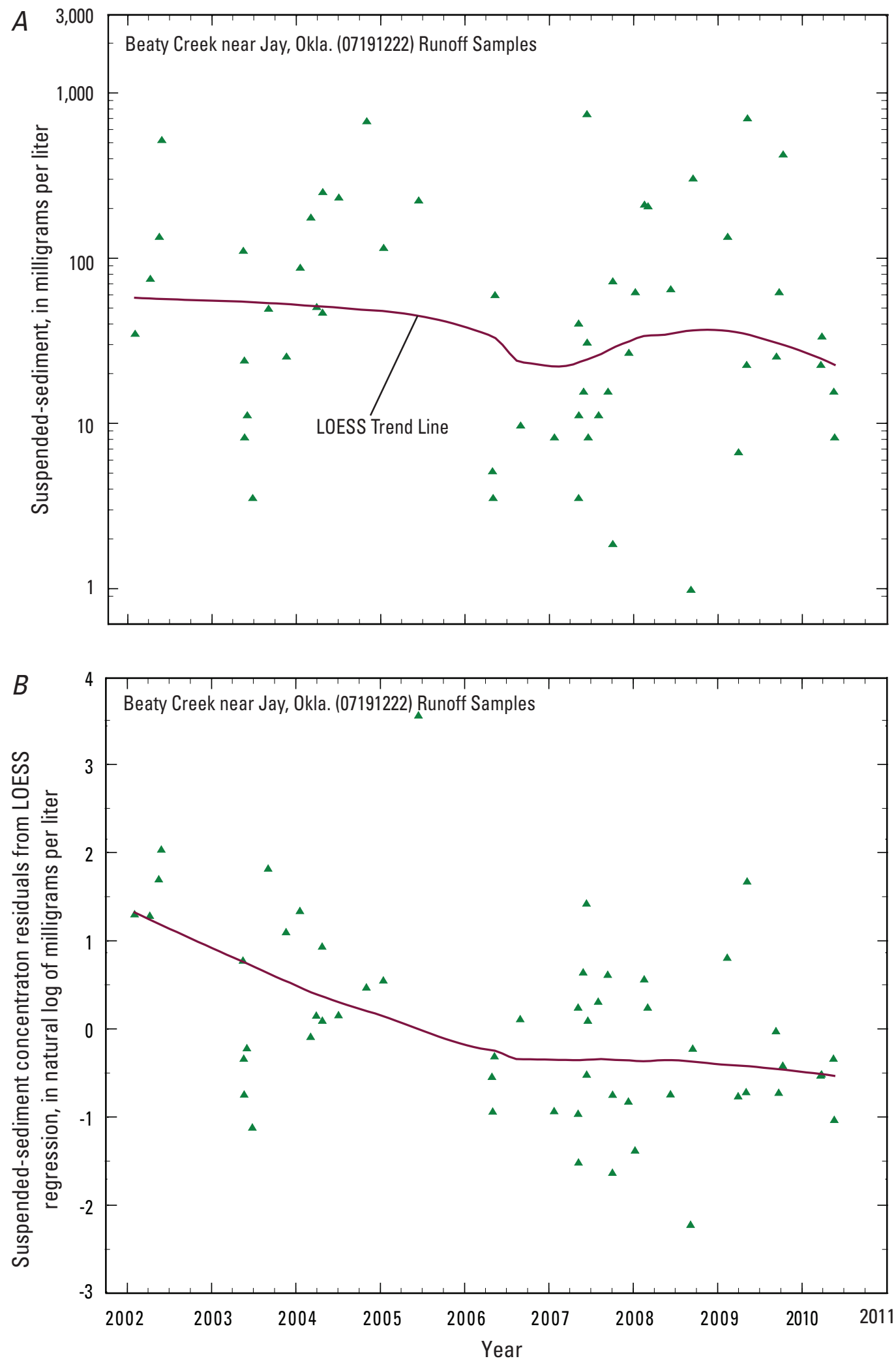

Figure 30. Suspended-sediment concentrations and LOESS trend lines at Beaty Creek near Jay, Oklahoma, showing $(A)$ suspendedsediment concentrations with time, and (B) flow-adjusted suspended-sediment concentrations (error residuals) from a LOESS egression. 
The significant upward trend in phosphorus concentrations in base-flow samples at the Maysville station could not be easily explained because there are no known substantial point sources of nitrogen and phosphorus upstream from this station, and increases in BMP implementation and reduction in poultry-litter application started in this basin in 2003-04. Similar to upward trends in phosphorus concentrations from runoff samples at Beaty Creek, long-term phosphorus storage in channel sediments may have served as a source of phosphorus in this stream.

Significant decreases in sediment concentrations at the Maysville, Sycamore, and Beaty Creek stations (figs. 28-30, table 10) indicated that BMPs may have reduced erosion of hillslopes and streambanks. However, because there were no significant trends in sediment concentration at the Cherokee City and Colcord stations, changes in sediment transport caused by BMPs probably were variable and affected by local sediment erosion and deposition in Spavinaw Creek. Because no significant trends in sediment concentrations were observed for the Colcord station, the flow-adjusted sediment load to Lake Eucha contributed from Spavinaw Creek may not have decreased over the study period. However, because a majority of the sediment load to Lake Eucha may have been contributed from the Beaty Creek basin (table 5), flow-adjusted sediment contributions to Lake Eucha may have decreased over the study period.

\section{Summary}

The City of Tulsa, Oklahoma, uses Lake Eucha and Spavinaw Lake in the Eucha-Spavinaw basin in northwestern Arkansas and northeastern Oklahoma for public water supply. The City has spent millions of dollars from 1998 through 2005 to eliminate taste and odor problems in the drinking water from the Eucha-Spavinaw system that have been attributed to blue-green algae. Increases in algal biomass in the lakes may be caused by increases in nitrogen and phosphorus concentrations in the lakes derived from streams discharging to the lakes.

In July 2001, the U.S. Geological Survey, in cooperation with the city of Tulsa supplemented monthly water-quality sampling with six runoff samplings per year for four stations on Spavinaw Creek and one station on Beaty Creek to better characterize water-quality conditions over the range of streamflows in the basin.

Daily mean load $\left(\mathrm{DM}_{\mathrm{L}}\right)$ regression equations were developed using data collected from 2002-10 to estimate nitrogen, sediment, and phosphorus loads and yields at the five streamflow-gaging stations in the basin. Instantaneous nitrogen, phosphorus, and sediment concentrations were estimated from regression equations (instantaneous-continuous or $\mathrm{INST}_{\mathrm{C}}$ regressions). $\mathrm{INST}_{\mathrm{C}}$ regressions were developed to estimate real-time nitrogen, phosphorus, and sediment concentrations using continuous measurements of physical water-quality constituents and streamflow in conjunction with periodic water-quality samples from 2004-10 for the Beaty Creek and Colcord stations. INST ${ }_{\mathrm{C}}$ regressions also were used to estimate daily and annual load for these three constituents. Daily, annual, and mean annual loads estimated from these two regression methods were compared for the Beaty and Colcord stations for 2005-10. $\mathrm{DM}_{\mathrm{L}}$ regressions for nitrogen and phosphorus had better fit to field data than $\mathrm{DM}_{\mathrm{L}}$ regressions for sediment for all stations as indicated by coefficient of determination $\left(\mathrm{R}^{2}\right)$ values. Differences in nitrogen and phosphorus loads and yields were similar to those reported for the period 2002-09 in the basin. The range in the runoff component of the mean annual total nitrogen load was 66 to 71 percent for the Spavinaw Creek stations and 87 percent for Beaty Creek. The range in the runoff component of the mean annual total phosphorus load was 78 to 92 percent for the Spavinaw Creek stations and 97 percent for Beaty Creek. The range in the runoff component of the mean annual total sediment load was 96 to 99 percent for the Spavinaw Creek stations and 100 percent for Beaty Creek. Runoff components of nitrogen and phosphorus were about 1 to 2 percent less for 2002-10 than those in 2002-09.

As estimated from the $\mathrm{DM}_{\mathrm{L}}$ regression, Spavinaw Creek and Beaty Creek contributed a mean annual total nitrogen load of $1,640,000$ pounds per year (lbs/yr), a mean annual total phosphorus load of 100,000 lbs/yr, and a mean annual total sediment load of 116,000,000 lbs/yr to Lake Eucha. Annual nitrogen and phosphorus loading to Lake Eucha computed from 2002-10 were 2.5 to 7.8 percent less than from 2002-09, indicating that nitrogen and phosphorus loads in 2010 were less than average compared to 2002-09.

Comparison of load-estimation equations indicated that daily, annual, and mean annual load estimates varied substantially depending on the independent variables used to develop regressions and on streamflow conditions. Fit cannot be compared between the $\mathrm{DM}_{\mathrm{L}}$ and $\mathrm{INST}_{\mathrm{C}}$ regressions using the changes in $\mathrm{R}^{2}$, but alternate $\mathrm{INST}_{\mathrm{C}}$ regressions that used streamflow and seasonality indicated potential differences in fit between the regression methods. For all nitrogen, phosphorus, and sediment at both stations, concentrations estimated from $\mathrm{INST}_{\mathrm{C}}$ regressions fit the field data better than estimates from alternate $\mathrm{INST}_{\mathrm{C}}$ regressions as indicated by $\mathrm{R}^{2}$ and root-mean-square error (RMSE).

Mean annual nitrogen loads computed by both types of regression methods were not substantially different for the Beaty Creek and Colcord stations (within 2 percent). Mean annual total phosphorus loads were not substantially different between regression methods for both stations. The $\mathrm{DM}_{\mathrm{L}}$ regression may have substantially underestimated phosphorus load at the Colcord station in wet years because of poorer fit and use of daily mean streamflow, which may 
have underestimated loads during peak-flow conditions. Mean annual total sediment loads estimated from the $\mathrm{DM}_{\mathrm{L}}$ regression were substantially greater than those estimated from the $\mathrm{INST}_{\mathrm{C}}$ regression for both stations. The relative percent differences between those two types of regression estimates mean annual total sediment loads at the Colcord station were -38.6 percent for the Colcord station and -122.7 percent for the Beaty Creek station. The $\mathrm{DM}_{\mathrm{L}}$ regression may have substantially overestimated sediment load at both stations in wet years, which notably affected computation of mean annual phosphorus load.

Trends in flow-adjusted nitrate-nitrate, nitrogen, phosphorus, and sediment concentrations were analyzed for the five stations for the period 2002-10. Significant temporal trends were not detected for nitrate plus nitrite-nitrogen or total nitrogen concentrations for either flow condition at any of the stations. Significant upward trends in phosphorus concentrations were observed for the Maysville station for base-flow samples and for runoff samples from the Beaty Creek station and ranged from 3.5 to 4.2 percent per year. Significant downward trends in phosphorus concentrations from base-flow and runoff samples were observed for the Cherokee City, Sycamore, and Colcord stations and ranged from -4.9 to -12.9 percent per year. No significant downward trends in sediment concentration were observed for the Maysville, Sycamore, and Beaty Creek stations, which ranged from -1.5 to -1.8 percent per year, and no significant trends in sediment concentration were observed for the Cherokee City or Colcord stations.

Reduction in phosphorus discharges from the Decatur, Arkansas, wastewater-treatment plant following upgrades to the plant in 2006 may have contributed to downward trends in phosphorus concentrations at the three closest Spavinaw Creek stations downstream from the plant. However, the largest decreases in phosphorus concentrations took place prior to reduction in phosphorus discharges in 2006. Causes of downward trends in phosphorus concentrations at the downstream Spavinaw Creek stations prior to changes in the wastewater-treatment plant in 2006 and implementation of best management practices in 2003 to 2004 are unknown.

Significant upward trends in phosphorus concentrations and significant downward trends in sediment concentrations at the Beaty Creek station were observed for runoff samples, indicating that the amount of phosphorus adsorbed to sediment transported during runoff may have increased with time even though sediment concentrations decreased. Factors contributing to a significant upward trend in phosphorus concentration in base-flow samples from the Maysville station were unknown. Decreases in sediment concentrations at the Maysville, Sycamore, and Beaty Creek stations indicate that best management practices may have contributed to local decreases in sediment erosion.

\section{References Cited}

Adamski, J.C., Petersen, J.C., Freiwald, D.A., and Davis, J.V., 1995, Environmental and hydrologic setting of the Ozark Plateaus study unit, Arkansas, Kansas, Missouri, and Oklahoma: U.S. Geological Survey Water-Resources Investigations Report 94-4022, 69 p.

Birkinshaw, S.J., and Bathurst, J.C., 2006, Model study of the relationship between sediment yield and river basin area: Earth Surface Processes and Landforms, v. 31, no. 6, p. 750-761.

Bradu, Dan, and Mundlak, Yair, 1970, Estimation in lognormal linear models: Journal of the American Statistical Association, v. 65, no. 329, p. 198-211.

Christensen, V.G., Esralew, R.A., and Allen, M.L., 2008, Estimated nutrient concentrations and continuous water-quality monitoring in the Eucha-Spavinaw basin, northwestern Arkansas and northeastern Oklahoma, 2004 2007: U.S. Geological Survey Scientific Investigations Report 2008-5218, 32 p.

City of Tulsa, 2008a, Water supply lakes - Eucha and Spavinaw watersheds: City of Tulsa City Services, accessed June 2008, at http://www.cityoftulsa.org/CityServices/ Water/EuchaSpavinaw.asp.

City of Tulsa, 2008b, Water treatment - History: City of Tulsa City Services, accessed June 2008, at http://www. cityoftulsa.org/CityServices/Water/TreatmentHistory.asp.

City of Tulsa, 2008c, Water treatment process: City of Tulsa City Services, accessed June 2008, at http://www. cityoftulsa.org/CityServices/Water/TreatmentProcess.asp.

City of Tulsa, 2010, City of Tulsa's comprehensive watershed management approach: City of Tulsa Office of Water memorandum, $6 \mathrm{p}$.

Clark, G.M, Mueller, D.K., and Mast, M.A., 2000, Nutrient concentrations and yields in undeveloped stream basins of the United States: Journal of the American Water Resources Association, v. 36, no. 4, p. 849-860.

Cleveland, W.S., and Devlin, S.J., 1988, Locally-weighted regression: An approach to regression analysis by local fitting: Journal of American Statistical Association, v. 83, p.596-610.

Cohn, T.A., DeLong, L.L., Gilroy, E.J., Hirsch, R.M., and Wells, D.K., 1989, Estimating constituent loads: Water Resources Research, v. 25, no. 5, p. 937-942. 
Crawford, C.G., 1991, Estimation of suspended-sediment rating curves and mean suspended-sediment loads: Journal of Hydrology, v. 129, p. 331-348.

Daniel, T.C., Sharpley, A.N., and Lemunyon, J.L., 1998, Agricultural phosphorus and eutrophication-A symposium overview: Journal of Environmental Quality, v. 27, no. 2, p. 251-257.

DeLaune, P.B., Haggard, B.E., Daniel, T.C., Chaubey, Indrajeet, and Cochran, M.J., 2006, The Eucha/Spavinaw phosphorus index-A court mandated index for litter management: Journal of Soil and Water Conservation, v. 61 , no. 2 , p. $1-10$.

Duan, Naihua, 1983, Smearing estimate-A nonparametric retransformation method: Journal of the American Statistical Association, v. 78, no. 383, p. 605-610.

Edwards, T.K, and Glysson, G.D., 1999, Field methods for measurement of fluvial sediment: U.S. Geological Survey Techniques of Water-Resources Investigations, book 3, chap. C2, 89 p.

Esralew, R.A., and Tortorelli, R.L., 2010, Nutrient concentrations, loads, and yields in the Eucha-Spavinaw basin, Arkansas and Oklahoma, 2002-09: U.S. Geological Survey Scientific Report 2010-5119, 61 p.

Fenneman, N.M., 1938, Physiography of eastern United States: New York, McGraw-Hill, p. 631-662.

Gilroy, E.J., Hirsch, R.M., and Cohn, T., 1990, Mean square error of regression-based constituent transport estimates: Water Resources Research, v. 26, no. 9, p. 2,069-2,077.

Haggard, B.E., 2000, Stream nutrient retention in the Lake Eucha-Spavinaw basin: Stillwater, Okla., Oklahoma State University, Ph.D. Dissertation, 165 p.

Haggard, B.E., Storm, D.E., and Stanley, E.H., 2001, Effect of a point source input on stream nutrient retention: Journal of the American Water Resources Association, v. 37, no. 5, p. 1,291-1,299.

Haggard, B.E., and Stoner, R.J., 2009, Long-term changes in sediment phosphorus below a rural effluent discharge: Hydrology and Earth Systems Science Discussions, v. 6, p. 767-798.

Helsel, D.R., and Hirsch, R.M., 1992, Statistical methods in water resources: Amsterdam, Netherlands, Elsevier, 522 p.

Institute of Hydrology, 1980a, Low flow studies: Wallingford, Oxon, United Kingdom, Report No. 1, 41 p.
Institute of Hydrology, 1980b, Low flow studies: Wallingford, Oxon, United Kingdom, Report No. 3, p. 12-19.

Kendall, M.G., 1975, Rank correlation methods: London, United Kingdom, Charles Griffin, 202 p.

Kendall, M.G., and Gibbons, J.D., 1990, Rank correlation methods (5th ed.): New York, Oxford University Press, $260 \mathrm{p}$.

National Oceanic and Atmospheric Administration, 2011, Climate Division: Temperature-Precipitation Drought-Data, National Climatic Data Center, accessed March 2011, at http://lwf.ncdc.noaa.gov/oa/climate/onlineprod/drought/ offline/ftppage.html.

Oklahoma Climatological Survey, 2009, OCS coop data tools: Oklahoma Climatological Survey, accessed May 2010, at climate.ok.gov/index.php.climate.

Oklahoma Conservation Commission, 2007, Water quality continues to improve in Spavinaw Watershed: Oklahoma Conservation News Archive, accessed May 2010, at http:// www.ok.gov/conservation/News/Water_Quality_Continues to_Improve_in_Spavinaw_Watershed.html.

Oklahoma Conservation Commission, 2009, Spavinaw Creek/ Beaty Creek watershed implementation projects: Oklahoma Conservation Commission Water Quality Division Fact Sheet, accessed May 2011, at http://www.ok.gov/ conservation/documents/2009_3_24\%20Spavinaw\%20 Beaty\%20Fact\%20Sheet.pdf.

Oklahoma Department of Environmental Quality, 2007, Eucha/Spavinaw watershed riparian protection initiative: Oklahoma's FY 07/08 319(h) CA\# C9-996100-14 Project 13, accessed May 2011, at http://www.environment.ok.gov/ documents/CWA/GrantWorkplans/Eucha-Spavinaw $\% 20$ Watershed\%20Riparian\%20Protection\%20Initiative/ WorkplanApproved10-07.pdf.

Oklahoma Water Resources Board, 2002, Water quality evaluation of the Eucha/Spavinaw Lake system, 528 p.

Petersen, J.C., Adamski, J.C., Bell, R.W., Davis, J.V., Femmer, S.R., Freiwald, D.A., and Joseph, R.L., 1998, Water quality in the Ozark Plateaus, Arkansas, Kansas, Missouri, and Oklahoma, 1992-95: U.S. Geological Survey Circular 1158, accessed July 2003, at http://water.usgs.gov/pubs/circ/ circ1158.

Phillips, G., Kelly, A., Pitt, J.O., Sanderson, R., and Taylor, E., 2005, The recovery of a very shallow eutrophic lake, 20 years after the control of effluent derived phosphorus: Freshwater Biology, v. 15, no. 50, p. 1,628-1,638. 
Rantz, S.E. and others, 1982, Measurement and computation of streamflow_-Volume 2, computation of discharge: U.S Geological Survey Water-Supply Paper 2175, v. 2, 285 p.

Rasmussen, T.J., Ziegler, A.C., and Rasmussen, P.P., 2005, Estimation of constituent concentrations, densities, loads, and yields in lower Kansas River, northeast Kansas, using regression models and continuous water-quality monitoring, January 2000 through December 2003: U.S. Geological Survey Scientific Investigations Report 2005-5165, 117 p.

Reddy, K.R., Kadlec, R.H., Flaig, E., and Gale, P. M., 1999, Phosphorus retention in streams and wetlands: A review: Critical Reviews in Environmental Science and Technology, v. 29 , p. 83-146.

Sharpley, A.N., 1995, Fate and transport of nutrientsPhosphorus: U.S. Department of Agriculture, Agricultural Research Service Working Paper No. 8, 28 p.

Schertz, T.L., Alexander, R.B., and Ohe, D.J., 1991, The computer program estimate trend (ESTREND), A system for the detection of trends in water-quality data: U.S. Geological Survey Water-Resources Investigations Report 91-4040, 61 p.

Sen, P.K., 1968, On a class of aligned rank order tests in two-way layouts: Annals of Mathematical Statistics, v. 39, p. 1,115-1,124.

Storm, D.E., White, Michael, Smolen, M.D., and Zhang, Hailin, 2001, Modeling phosphorus loading for the Lake Eucha basin: Stillwater, Okla., Oklahoma State University, Biosystems and Agricultural Engineering Department, 14 p.

Storm, D.E., White, M.J., and Smolen, M.D., 2002, Modeling the Lake Eucha basin using SWAT 2000: Stillwater, Oklahoma, Oklahoma State University, Biosystems and Agricultural Engineering Department, 60 p.

Tortorelli, R.L., 2006, Nutrient concentrations, loads, and yields in the Eucha-Spavinaw basin, Arkansas and Oklahoma, 2002-2004: U.S. Geological Survey Scientific Investigations Report 2006-5250, 44 p.

Tortorelli, R.L., 2008, Nutrient concentrations, loads, and yields in the Eucha-Spavinaw basin, Arkansas and Oklahoma, 2002-2006: U.S. Geological Survey Scientific Investigations Report 2008-5174, 56 p.

Tulsa Metropolitan Utility Authority, 2001, Eucha/Spavinaw watershed project: accessed August 2006, at http://www. cityoftulsa.org/city-services/water/eucha-spavinawwatersheds.aspx.
U.S. Census Bureau, 2009, County population estimates: U.S. Census Bureau Population Estimates, accessed June 10, 2010, at http://www.census.gov/popest/counties/ CO-EST2009-01.html.

U.S. Department of Agriculture, 2004, The census of agriculture: 2002 census report, accessed April 2010, at http://www.agcensus.usda.gov/Publications/2002/index.asp.

U.S. Department of Agriculture, 2009, The census of agriculture: 2007 census report, accessed April 2010, at http://www.agcensus.usda.gov/Publications/2007/index.asp.

U.S. Environmental Protection Agency, 1983, Methods for chemical analysis of water and wastes, Method 365.2 (2d ed.): EPA-600/4-79-20 revised March 1983 [variously paged].

U.S. Environmental Protection Agency, 1993, Methods for the determination of inorganic substances in environmental samples: EPA-600/R-93-100 [variously paged].

U.S. Environmental Protection Agency, 2007, Section 319 Nonpoint source program success story Oklahoma: BMPs result in significant reduction of bacteria and phosphorus loading: EPA 841-F-07-001D, accessed March 2011, at http://www.epa.gov/owow/NPS/Success319/state/pdf/ ok_beaty.pdf.

U.S. Environmental Protection Agency, 2008, 2001 National Land Cover Database (NLCD): Multi-Resolution Land Characteristics Consortium, accessed August 2008, at http://www.epa.gov/mrlc/nlcd-2001.html.

U.S. Environmental Protection Agency and Oklahoma Department of Environmental Quality, 2009, TMDL development for Lakes Eucha and Spavinaw in Oklahoma, accessed March 2010, at http://www.deq.state.ok.us/ wqdnew/tmdl/eucha_spavinaw/eucha_lk_spavinaw_\%20 ck_\%20final_tmdl_2009-09-01.pdf.

U.S. Geological Survey, 1999, The quality of our Nation's waters-Nutrients and pesticides: U.S. Geological Survey Circular 1225, 82 p.

U.S. Geological Survey, 2006, National field manual for the collection of water-quality data, collection of water samples: U.S. Geological Survey Techniques of WaterResources Investigations, book 9, chap. A4, 166 p., available online at http://water.usgs.gov/owq/FieldManual/ chapter4/pdf/Chap4_v2.pdf. (accessed August, 2011.) 
Wagner, Kevin, and Woodruff, Scott, 1997, Phase I clean lakes project, diagnostic and feasibility study of Lake Eucha: Oklahoma Conservation Commission, Final Report, accessed July 2011, at http://www.okcc.state.ok.us/WQ/ WQ_reports/REPORT031.pdf.

Wagner, R.J., Boulger, R.W., Jr., Oblinger, C.J., and Smith, B.A., 2006, Guidelines and standard procedures for continuous water-quality monitors: Station operation, record computation, and data reporting: U.S. Geological Survey Techniques and Methods 1-D3, 51 p. (Also available at http://pubs.water.usgs.gov/tm1d3.)

Wahl, K.L., and Wahl, T.L., 1995, Determining the flow of Comal Springs at New Braunfels, Texas, in Proceedings of Texas water, '95, A Component Conference of the First International Conference on Water Resources Engineering, San Antonio, Texas, American Society of Civil Engineers Symposium, August 16-17, 1995: American Society of Civil Engineers, p. 77-86.

Wilcoxon, Frank, 1945, Individual comparisons by ranking methods: Biometrics Bulletin, v. 1, no. 6, p. 80-83. 


\section{$\frac{2}{2}$}

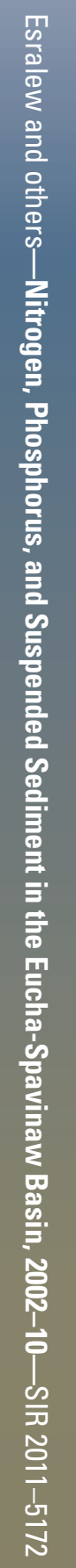

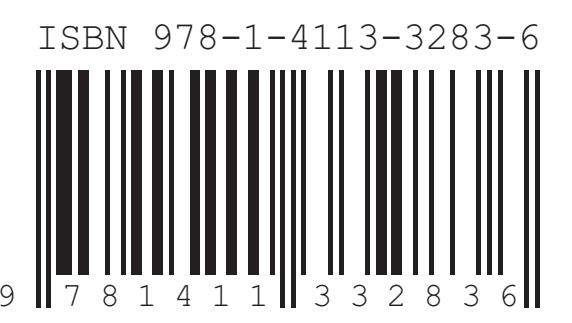

